Gustavo de Alencastro

\title{
Identificação e estudo funcional de genes associados com Doenças Neurológicas
}

\author{
Instituto de Biociências \\ Universidade de São Paulo \\ São Paulo \\ 2008
}


Gustavo de Alencastro

\title{
Identificação e estudo funcional de genes associados com Doenças Neurológicas
}

\author{
Dissertação apresentada ao \\ Instituto de Biociências da \\ Universidade de São Paulo, para a \\ obtenção de Título de Mestre em \\ Ciências, \\ na \\ Área de \\ Biologia/Genética. \\ Orientadora: Profa. Dra. Maria Rita \\ dos Santos e Passos-Bueno \\ Co-orientadora: Dra. Andréa \\ Laurato Sertié
}

São Paulo 


\section{Ficha Catalográfica}

Alencastro, Gustavo.

Identificação e estudo funcional de genes associados com Doenças Neurológicas.

Número de páginas

Dissertação (Mestrado) - Instituto de Biociências da Universidade de São Paulo. Departamento de Genética e Biologia Evolutiva.

1. Doenças neurológicas 2. Retardo mental ligado ao cromossomo X 3. Colibistina (gene ARHGEF9). Universidade de São Paulo. Instituto de Biociências. Departamento de Genética e Biologia Evolutiva.

\section{Comissão Julgadora:}

$\operatorname{Prof}(a) . \operatorname{Dr}(a)$.

$\operatorname{Prof}(a) . \operatorname{Dr}(a)$.
Prof(a). Dr(a).

Prof(a). Dr(a). 


\section{Dedicatória}

Aos meus pais e minha irmã,

pelo exemplo, amor e incentivo 


\section{Agradecimentos}

À minha orientadora, Profa. Maria Rita Passos-Bueno, por todo o ensinamento e oportunidades concedidas. É um exemplo de pessoa e pesquisadora, e teve uma grande influência no meu interesse pela ciência.

À minha co-orientadora, Dra. Andréa Laurato Sertié, por ter me ensinado praticamente tudo que aprendi durante todos estes anos no laboratório. Sua educação, bondade, competência, dedicação e, acima de tudo, amizade foram muito importantes para mim.

Aos colegas e amigos que estão no laboratório ou já passaram por ele: Aline, Bia, Camila, Carlos, Ciba, Cristian, Dani, Érikinha, Fernanda, Flávia, Gérson, Giovana, Gui, Juliana, Karina, Kelly, Lúcia, Luciano, Mayara, Meire, Nélio, Oscar, Roberto, Thais e Vanessa. Muito obrigado por todos os ótimos momentos dentro e fora do laboratório!

À Érika Kague por todo o apoio e carinho.

Aos colegas do Instituto de Biociências: Centro de Estudos do Genoma Humano (em especial à Marta, Kátia, Vanessa, Camila, Roberto, Lilian e Valter); laboratórios da Dra. Mayana Zatz (em especial à Toninha, Miguel e Constância), Dra. Célia Koiffmann, Dra. Cristina Miyaki, Dr. Luís Soares Netto (em especial ao José Renato), Dra. Mariz Vainzof (em especial à Dani e Martinha), Dra. Luciana Haddad, Dr. Eduardo Gorab (em especial à Cris) e Dra. Ângela Morgante.

À Dra. Mari Sogayar por disponibilizar o seu laboratório (IQ-USP) para a realização de experimentos, e ao seu aluno Dr. Fernando Lojudice por estar sempre disponível no que fosse necessário. 
À Dra. Beatriz Castilho por disponibilizar o seu laboratório (UNIFESP) para a realização de experimentos, e ao seu aluno de Doutorado Martin Roffe pela ajuda com os experimentos e discussões pertinentes.

Ao Dr. Charles Schwartz por possibilitar uma colaboração em seu laboratório em Greenwood/SC - EUA, compartilhar o seu conhecimento e amizade, além de disponibilizar todo o material necessário para a realização da pesquisa.

Aos colegas do laboratório de Greenwood: Joy Norris, Caedyn, Julia, Luigi Boccuto, Lynn, Kelly, Fátima, Megan, Melani, Karl, Kyoco e Yue Luo.

À família Skinner e amigos que me acolheram na minha estada em Greenwood e me fizeram sentir como se eu estivesse na minha própria casa.

À FAPESP e CNPq pelo apoio financeiro.

Aos meus amigos do time de futebol e aos amigos que dividiram moradia comigo (Daniel, Fábio, Gabriel, Marcos e Matheus). Todos foram como uma segunda família para mim e sempre me ajudaram a espairecer e ficar de bom humor.

Aos meus amigos espalhados por São Paulo, Jundiaí, Campinas e Porto Alegre.

E principalmente à minha família, meus pais, minha irmã e meus avôs os quais sempre apoiaram e incentivaram, com muito amor e carinho, tudo que eu fiz na minha vida. Obrigado do fundo do coração! 


\section{Índice}

Capítulo 1 - Introdução Geral.........................................................................

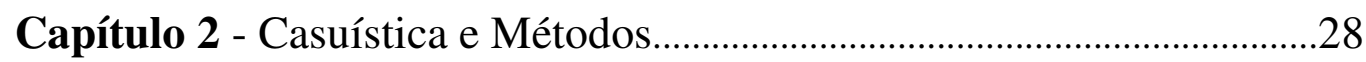

Capítulo 3 - Nova mutação em SMS leva a uma redução drástica na função da proteína espermina sintase e a uma forma grave de retardo mental sindrômico ligado ao cromossomo X síndrome de Snyder-Robinson....................................................54

Capítulo 4 - Análise de ARHGEF9, gene codificador da proteína colibistina, em pacientes com Hiperecplexia e em pacientes com Retardo Mental associado com Epilepsia.

Capítulo 5 - Colibistina e gefirina interagem com o complexo eIF3: uma nova função ligada à maquinaria de tradução protéica?......96

Capítulo 6 - Discussão Geral e Conclusões.

Capítulo 7 - Referências Bibliográficas. 124

Anexos e Apêndices. 


\section{Resumo}

Neste trabalho utilizamos diferentes abordagens para o estudo de genes associados com desenvolvimento e funcionamento do SNC assim como com doenças neurológicas: 1) uma das abordagens consistiu na identificação do alelo associado a uma forma de retardo mental sindrômico com herança recessiva ligada ao cromossomo X, síndrome de Snyder-Robinson, em uma família Brasileira. Utilizando as estratégias de estudo de ligação genética e análise de genes candidatos, identificamos a segunda mutação patogênica no gene SMS (que codifica a enzima espermina sintase) associada à síndrome de Snyder-Robinson. A identificação dessa mutação contribuiu para: delinear e expandir o espectro clínico da síndrome, evidenciar domínios importantes para o funcionamento da proteína espermina sintase, comprovar a importância dessa proteína nos processos cognitivos, e também possibilitar um aconselhamento genético preciso para membros da família; 2) outra abordagem consistiu em analisar (triar mutação) o gene codificador da proteína colibistina (ARHGEF9), a qual está envolvida em sinaptogênese inibitória, em pacientes Brasileiros portadores de hiperecplexia (6 pacientes) e em pacientes portadores de retardo mental associado com epilepsia (22 pacientes). Não identificamos nenhuma alteração patogênica no gene ARHGEF9 nos 28 pacientes estudados; contudo, o número de pacientes analisados foi muito pequeno. Julgamos que a análise de um número maior de pacientes com essas doenças neurológicas pode vir a revelar novas mutações deletérias em ARHGEF9; 3) a última abordagem consistiu no estudo funcional da proteína colibistina. Com o objetivo de identificar outras proteínas que interagem com a colibistina humana utilizamos o sistema de duplo-híbrido em leveduras e experimentos de co-imunoprecipitação in vitro e in vivo. Identificamos a proteína eIF3-p40 interagindo com a proteína colibistina e também com a proteína gefirina (a qual, por sua vez, também interage com colibistina e está envolvida com funcionamento de sinapses inibitórias). A proteína eIF3-p40 é uma das subunidades do complexo do fator 3 de iniciação de tradução protéica em eucariotos (eIF3). Essas interações ligam as proteínas colibistina e a gefirina à maquinaria de 
tradução protéica, revelando uma provável nova função dessas proteínas no controle da tradução em sítios pós-sinápticos inibitórios. 


\section{Abstract}

In this work we have used different approaches to the study of genes associated with CNS development and function as well as with neurological diseases: 1) one study involved the identification of the allele associated with an X-linked recessive sindromic form of mental retardation, Snyder-Robinson syndrome, in a Brazilian family. Using genetic linkage analysis and candidate gene strategy, we identified the second pathogenic mutation in the SMS gene (that encodes the spermine synthase enzyme) associated with the Snyder-Robinson syndrome. The identification of this mutation contributed to: the delineation and expansion of the clinical spectrum of the syndrome, highlight important domains for spermine synthase protein functioning, demonstrate the importance of this protein in cognitive processes, and also a precise genetic counseling for family members; 2) a second study involved the mutation screening of ARHGEF9 gene encoding the collybistin protein, which is involved in inhibitory synaptogenesis, in Brazilian patients with hyperekplexia (6 patients) and in patients with mental retardation associated with epilepsy (22 patients). We did not identify any pathogenic alteration in the ARHGEF9 gene in the 28 studied patients, but the number of patients analysed was very small. However, the possibility remains that additional mutations in ARHGEF9 may contribute to other cases of hyperekplexia and mental retardation associated with epilepsy; 3) the last study involved the functional analysis of collybistin protein. In order to identify other proteins that interact with human collybistin, we used the yeast two-hybrid system and in vitro and in vivo co-immunoprecipitation experiments. We identified the eIF3-p40 protein as collybistin and gephyrin (another protein involved in the function of inhibitory synapses that also interacts with collybistin) binding partner. The eIF3-p40 protein is one of the subunits of the eukaryotic initiation factor 3 complex (eIF3). These interactions link the collybistin and gephyrin proteins to the protein translation machinery, revealing a putative new role of these proteins in the translation control at inhibitory postsynaptic sites. 


\section{Capítulo 1}

\section{Introdução Geral}

\section{1) Sistema Nervoso}

O sistema nervoso dos vertebrados é um sistema complexo e sofisticado que regula e coordena as atividades e funções básicas do corpo. Ele é dividido em dois grupos: o sistema nervoso central (SNC), que consiste do encéfalo e espinha dorsal, e o sistema nervoso periférico (SNP), que é constituído basicamente pelos nervos cranianos e nervos raquidianos (Squire et al., 2002). O SNC controla os pensamentos, comportamentos e movimentos, e o SNP transmite informações para o SNC para esse transmitir mensagens aos músculos e glândulas. O SNP, por sua vez, pode ser dividido em voluntário (somático) e autônomo (visceral), onde o último ainda é subdividido em simpático e parasimpático. O SNP voluntário é reponsável pelo controle de diversas atividades concientes (como por exemplo movimentar um braço e mudar a expressão facial). Já o SNP autônomo é responsável pelo controle de ações que ocorrem independentemente da vontade (como por exemplo os batimentos cardíacos e os processos de digestão e excreção) (Squire et al., 2002).

O sistema nervoso possui uma grande variedade de tipos e de tamanhos celulares, organizados de uma maneira altamente específica. A conexão precisa e rápida entre um tipo celular particular e outro, sobretudo a sequiência em que as células se comunicam, é fundamental para o correto funcionamento do sistema nervoso. Se, por exemplo, essa seqüência de comunicação é rompida, seja por uma injúria, doença, ou malformação do desenvolvimento, importantes funções controladas pelo sistema nervoso estarão prejudicadas (Butler \& Hodos, 1996).

As células do SNC podem ser agrupadas em duas amplas categorias: neurônios e células da glia. Os neurônios são as células responsáveis pela comunicação e processamento de informação no SNC. As células da glia são elementos suporte: elas protegem e nutrem os neurônios, mas podem possuir também uma tênue função no processamento de informações (Butler \& Hodos, 1996). 


\subsection{1) Os neurônios}

Os principais componentes dos neurônios são: os dentritos, o axônio e o corpo celular (Figura 1). Os dendritos são responsáveis pela recepção dos estímulos transmitidos pelos outros neurônios; os axônios são responsáveis por trasmitir os estímulos para outros neurônios (e, por serem constituídos de fibras tubulares que podem alcançar até alguns metros, permitem comunicações a longas distâncias); o corpo do neurônio é responsável por coletar e combinar informações vindas de outros neurônios, além de ser o local de produção de muitos materiais importantes para a manutenção das funções internas e externas do neurônio. Esses materiais incluem enzimas e outras substâncias que participam da síntese de neurotransmissores e neuromoduladores, proteínas que atuam na formação de vesículas sinápticas, canais iônicos, receptores de membrana, e proteínas para a manutenção do esqueleto interno dos neurônios (Squire et al., 2002).

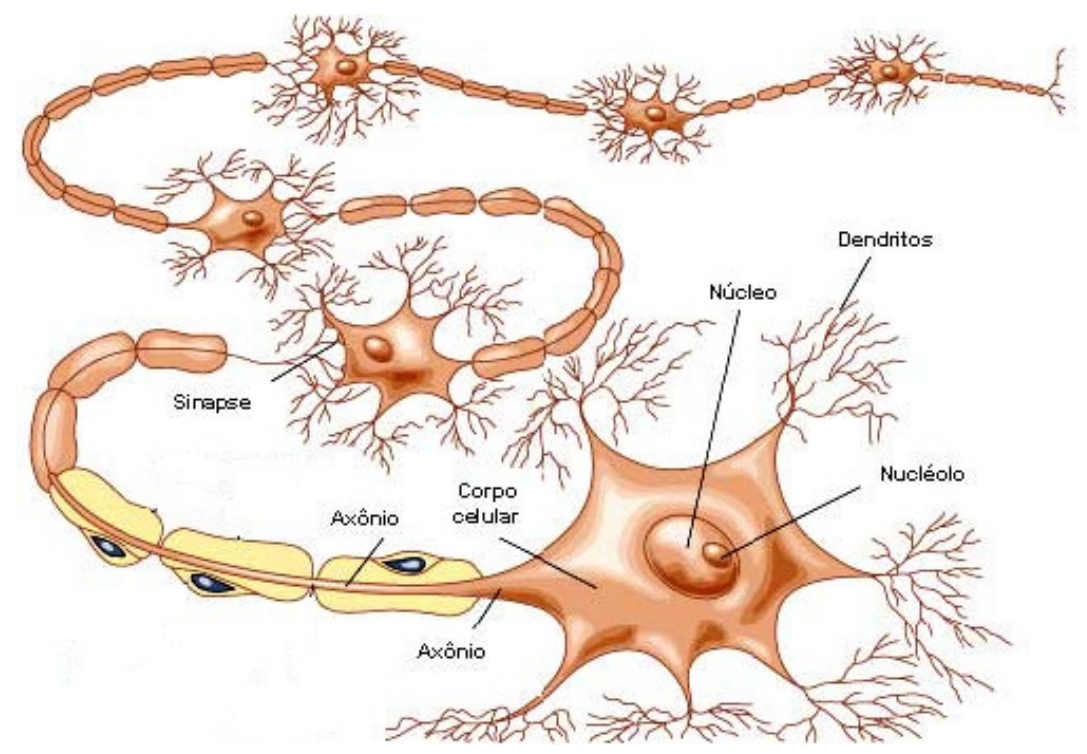

Figura 1. Representação de seis neurônios fazendo conexões por meio de suas sinapses. No maior neurônio estão indicados o corpo celular, núcleo, nucléolo, dendritos e axônio.

\section{2) Comunicacão neuronal}

Os neurônios comunicam-se por meio de uma sinalização que na maioria dos casos é química, algumas vezes elétrica, e ocasionalmente uma mistura de ambas, a 
qual ocorre em regiões denominadas de sinapses nervosas (item 1.2.1). A maior parte das sinapses ocorre no contato do axônio de um neurônio com os dendritos ou corpo celular de outro neurônio ou célula muscular (Figura 1).

Quando a comunicação entre os neurônios precisa ser estabelecida a certa distância, a transmissão do sinal ao longo do comprimento do axônio é realizada por meio de um processo eletroquímico conhecido como impulso nervoso ou potencial de ação (onda de descarga elétrica que percorre a membrana do axônio) (Alberts et al., 1999) (Figura 2).
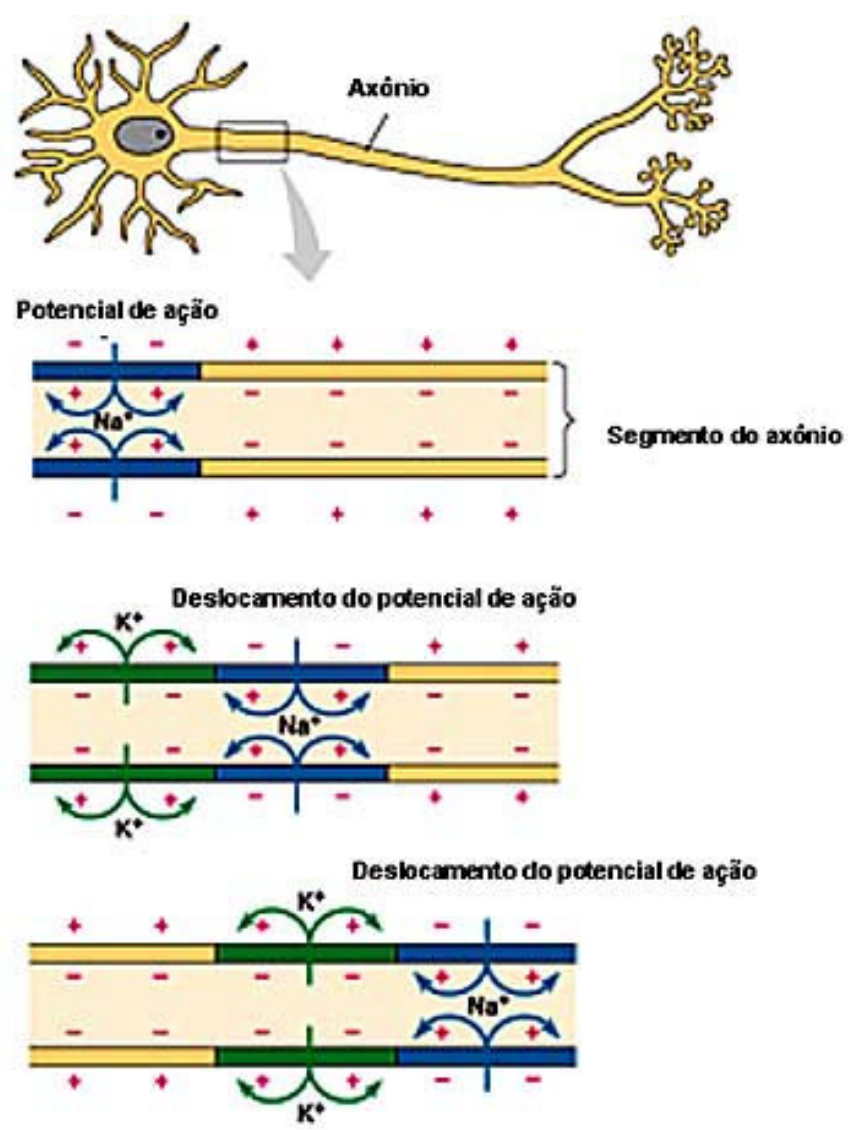

Figura 2. Representação da condução do potencial de ação em um neurônio. Uma voltagem elétrica, ou diferença de potencial, sempre existe entre o interior e o exterior de um neurônio (assim como de qualquer célula do corpo). Esse fato é causado por uma distribuição de íons desigual entre os dois lados da membrana celular e da permeabilidade da membrana a esses íons. A voltagem de um neurônio inativo permanece em um valor negativo - considerando o interior da célula em relação ao exterior - e varia muito pouco. Quando a membrana de um neurônio excitável é despolarizada além de um limiar, a célula dispara um potencial de ação. O potencial 
de ação é uma alteração rápida na polaridade da voltagem, de negativa para positiva e de volta para negativa (esse ciclo completo dura poucos milisegundos). Essa alteração na voltagem ocorre quando a entrada de íons positivos (pricipalmente de sódio) na célula excede a saída de íons negativos (principalmente de potássio). O influxo líquido de cargas positivas devido aos íons de sódio causa a despolarização da membrana, levando à abertura de mais canais de sódio dependentes de voltagem. Por esses canais passa uma grande corrente de entrada de sódio, que causa maior despolarização, que leva o potencial de membrana a um nível bastante despolarizado.

\subsection{1) Sinapses}

As sinapses são as regiões de comunicação entre os neurônios. Elas são essenciais para praticamente todas as funções do sistema nervoso, como a percepção sensorial, coordenação de movimentos, aprendizagem e memória. Durante o desenvolvimento do sistema nervoso humano, trilhões de sinapses, ambas excitatórias e inibitórias, são formadas com uma especificidade extraordinária enquanto os neurônios crescem e fazem contatos uns com os outros.

A região do terminal axônico onde ele contacta outro neurônio é conhecida como membrana pré-sináptica, e a superfície especializada do neurônio que recebe o terminal axônico, normalmente localizada nos dendritos, é conhecida como membrana pós-sináptica. O contato físico direto entre as membranas pré e pós sinápticas não existe realmente, mas há um espaço entre elas denominado fenda sináptica.

As sinapses podem ser do tipo química, elétrica ou uma combinação de ambas. Contudo, a maioria das sinapses dos mamíferos são sinapses químicas.

- Sinapses Químicas: A maioria das sinapses químicas é constituída por um espaço extracelular (fenda sináptica) pequeno, possuindo aproximadamente 20-30 nm, e a transmissão do sinal entre as sinapses é feita por substâncias químicas neurotransmissoras. Dentro do terminal axônico (pré-sinápse) estão pequenas vesículas ligadas à membrana, as quais contêm neurotransmissores que são liberados para dentro da fenda sináptica após a chegada do potencial de ação (Butler \& Hodos, 1996). Assim, quando um potencial de ação chega a um terminal axônico, isso causa a abertura de canais de cálcio que permitem um influxo de íons de cálcio para dentro da célula. A chegada do influxo de cálcio resulta em um movimento das vesículas contendo as substâncias neurotransmissoras em direção a membrana pré-sináptica. As 
membranas das vesículas se fusionam com a membrana pré-sináptica permitindo que o conteúdo das vesículas possa ser liberado para dentro da fenda sináptica, onde ele atuará sobre receptores protéicos na membrana pós-sináptica. Se a substância neurotransmissora é excitatória (isto é, despolarizante), isso gera um potencial excitatório na membrana pós-sináptica. Se a substancia é inibitória, sua ação na membrana pós-sináptica atua aumentando a polarização da célula, isso é, aumentando o potencial de inércia da célula e fazendo com que seja mais difícil gerar um potencial de ação (fenômeno conhecido como hiperpolarização).

Assim sendo, os eventos elétricos (potencial de ação) propagam o sinal dentro de um neurônio, e os eventos químicos (neurotransmissores) transmitem o sinal de um neurônio a outro ou para uma célula muscular. Os neurotransmissores possibilitam que os impulsos nervosos de uma célula influenciem os impulsos nervosos de outra, permitindo assim que as células do cérebro "conversem entre si", por assim dizer. É importante salientar que a transmissão rápida de sinais entre os neurônios depende da alta concentração de receptores de neurotransmissores (canais iônicos) nos sítios póssinápticos, e esse controle é efetuado principalmente por proteínas do citoesqueleto.

As sinapses químicas podem ser caracterizadas pelos componentes químicos que estão presentes nelas, incluindo os neurotransmissores e os neuromoduladores. A categoria dos neurotransmissores possui relativamente poucos representantes, mas a categoria dos neuromoduladores contém mais de 30 (Tabela 1). Os neuromoduladores geralmente não influenciam na despolarização ou hiperpolarização dos neurônios como fazem os neurotransmissores. Em vez disso, os neuromoduladores interferem na duração ou intensidade da ação do neurotransmissor por influenciar na captação de neurotransmissores, na efetividade das enzimas presentes nas sinapses, na taxa de liberação do neurotransmissor, e ainda uma variedade de outros fenômenos os quais fazem das sinapses químicas um sistema complexo e altamente modulável (Butler \& Hodos, 1996).

- Sinapses Elétricas: Em muitas junções sinápticas a transmissão é realizada pela passagem de uma corrente elétrica por proteínas que conectam uma célula a outra, chamadas de conexinas. Essas junções são conhecidas como eletrônicas ou elétricas ou simplesmente como "gap". A fenda sináptica é de somente 2-4 nm, a qual é cerca de um décimo do espaço de uma sinapse química. Esse tipo de comunicação é mais 
rápida entre as células (um potencial de ação no neurônio pré-sináptico, pode produzir quase que instantaneamente um potencial de ação no neurônio pós-sináptico) do que a comunicação química, mas não tão modulável. Sinapses elétricas no sistema nervoso central de mamíferos são encontradas principalmente em locais especiais onde funções normais exigem que a atividade dos neurônios vizinhos seja altamente sincronizada (como por exemplo nos neurônios sensoriais) (Butler \& Hodos, 1996).

Tabela 1. Algumas das principais substâncias neuroativas do sistema nervoso central.

\begin{tabular}{|c|c|c|c|}
\hline Tipo & $\begin{array}{c}\text { Grupo } \\
\text { Químico }\end{array}$ & Substância & Função \\
\hline \multirow{10}{*}{ Neurotransmissores } & Colinérgicos & Acetilcolina & \multirow{6}{*}{$\begin{array}{c}\text { Excitatórios ou inibitórios } \\
\text { dependendo do tipo de } \\
\text { receptor }\end{array}$} \\
\hline & \multirow{5}{*}{$\begin{array}{l}\text { Aminas } \\
\text { biogênicas }\end{array}$} & Norepinefrina & \\
\hline & & Epinefrina & \\
\hline & & Dopamina & \\
\hline & & Serotonina & \\
\hline & & Histamina & \\
\hline & \multirow{4}{*}{ Aminoácidos } & Glutamato & \multirow[t]{2}{*}{ Excitatórios } \\
\hline & & Aspartato & \\
\hline & & GABA & \multirow[t]{2}{*}{ Inibitórios } \\
\hline & & Glicina & \\
\hline \multirow{15}{*}{ Neuromoduladores } & \multirow{14}{*}{$\begin{array}{l}\text { Peptídeos e } \\
\text { hormônios }\end{array}$} & VIP & \multirow{15}{*}{$\begin{array}{c}\text { Modulação da transmissão } \\
\text { sináptica por influenciar } \\
\text { na liberação do } \\
\text { neurotransmissor } \\
\text { ou na recaptação ou por } \\
\text { alterar a sensibilidade da } \\
\text { membrana } \\
\text { pós-sináptica ao } \\
\text { neurotransmissor. } \\
\text { Alguns neuromoduladores } \\
\text { possuem } \\
\text { uma atividade similar } \\
\text { ao dos neurotransmissores }\end{array}$} \\
\hline & & Substância P & \\
\hline & & Met-encefalina & \\
\hline & & Leu-encefalina & \\
\hline & & Colecistocinina & \\
\hline & & Somatostatina & \\
\hline & & Neurotensina & \\
\hline & & Bombesina & \\
\hline & & Beta-endorfina & \\
\hline & & Angiotensina II & \\
\hline & & Neuropeptídio Y & \\
\hline & & Hormônio ant. pituitária & \\
\hline & & Hormônio pos. pituitária & \\
\hline & & Insulina & \\
\hline & $\begin{array}{l}\text { Mensageiros } \\
\text { secundários }\end{array}$ & GMP cíclico & \\
\hline
\end{tabular}

\section{3) Doencas neurológicas}

O sistema nervoso é vulnerável a várias doenças, as quais afetam tanto o SNC quanto o SNP. Segundo dados da Organização Mundial da Saúde (2007), as doenças neurológicas afetam cerca de 1 bilhão de pessoas e causam a morte de 6,8 milhões por 
ano, o que equivale a $12 \%$ de todas as mortes mundiais. As doenças neurológicas mais freqüentes são a enxaqueca (326 milhões de pessoas afetadas), o retardo mental (150 milhões de pessoas afetadas), as doenças cerebrovasculares (62 milhões de pessoas afetadas), a epilepsia (50 milhões de pessoas afetadas) e a doença de Alzheimer (24 milhões de pessoas afetadas) (Figura 3). Devido a fatores como alta prevalência, gravidade, morbidade e impacto socioeconômico, as pesquisas científicas no campo das doenças neurológicas têm adquirido caráter prioritário nas políticas de saúde pública.

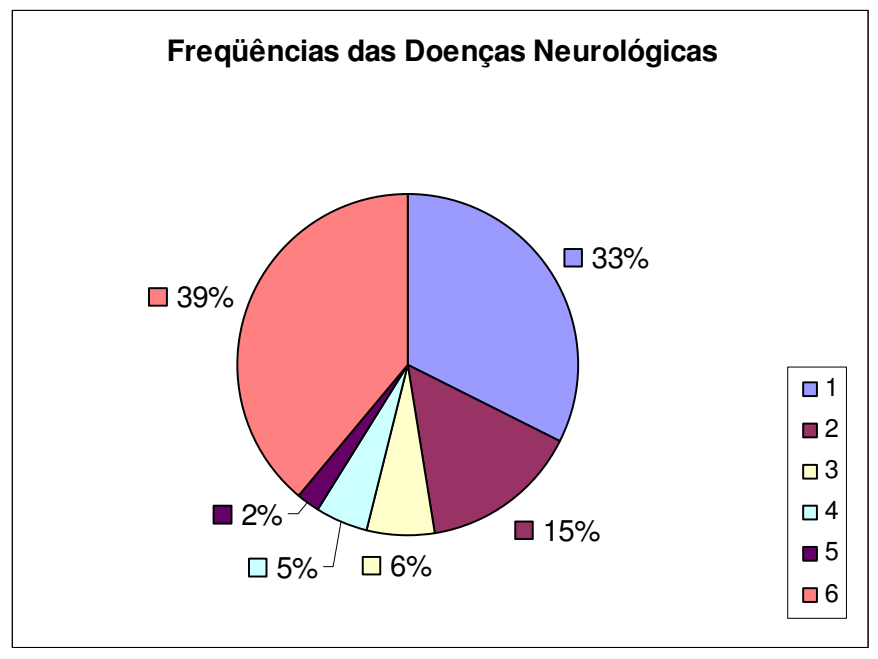

Figura 3. Gráfico representando as doenças neurológicas mais freqüentes na população mundial. 1- Enxaqueca; 2- Retardo Mental; 3- doenças Cerebrovasculares; 4-Epilepsia; 5- doença de Alzheimer; 6- Outras.

As doenças neurológicas possuem causas heterogêneas, podendo ser ambientais, genéticas ou ainda uma associação de ambas. Geralmente os mecanismos responsáveis por causar essas doenças incluem: isquêmica/hipóxia, danos por radicais livres, necrose e/ou apoptose, processos inflamatórios e imuno-mediados, diminuição da interação entre moléculas, seqüestro de moléculas essenciais, formação de agregados intra e extracelulares, aquisição de propriedades tóxicas por proteínas mutadas e reorganização patológica de circuitos neuronais (Price et al.,1999). Os sinais e sintomas decorrentes dessas alterações são extremamente variados e podem aparecer de forma isolada ou combinada, geralmente ocasionando alterações psíquicas 
(de memória, cognição, linguagem e personalidade), alterações motoras, alterações da sensibilidade, alterações da função dos nervos do crânio e da face e crises epilépticas.

Muitas das doenças neurológicas são associadas com alterações nas sinapses, aonde mutações foram descritas em genes codificadores de proteínas responsáveis pela ciclagem de vesículas pré-sinápticas (D'Adamo et al., 1998; Tabolacci et al., 2006), organizadoras dos complexos protéicos pós-sinápticos (Durand et al., 2006; Rees et al., 2003), controladoras dos processos de transcrição e tradução em sinapses (revisado em Johnston, 2004), reguladoras da dinâmica do citoesqueleto neuronal (Billuart et al., 1998; Kutsche et al., 2000), responsáveis pelo alinhamento das membranas pré e pós-sinápticas (Jamain et al., 2003; Laumonnier et al., 2004; Durand et al., 2007), entre outras.

Para a maioria das doenças neurológicas existe apenas tratamento sintomático. Felizmente, nos últimos anos, avanços significativos têm sidos feitos para desvendar as características genéticas e esclarecer os mecanismos patogênicos por trás de muitas doenças neurológicas. Essas pesquisas, além de permitirem uma melhor compreensão do funcionamento normal e em situações patológicas do sistema nervoso, estão sendo responsáveis pela identificação de novos alvos terapêuticos e a criação de novos tratamentos. Contudo, dado a complexidade do sistema nervoso e o enorme número de genes envolvidos em seu correto funcionamento, existe ainda muito a ser explorado e compreendido.

Neste trabalho utilizamos diferentes abordagens para o estudo de genes associados com desenvolvimento e/ou funcionamento do SNC. Essas abordagens incluem o estudo (análise de mutações) de genes associados com algumas doenças neurológicas (item 1.4) e o estudo funcional de uma proteína importante para a formação e funcionamento de sinapses inibitórias do SNC (item 1.5). Para fundamentarmos as abordagens adotadas realizamos revisão das doenças neurológicas de interesse para o presente estudo (item 1.4) e da proteína selecionada para estudo funcional (item 1.5). 


\section{4) Estudo de genes associados com doencas neurológicas}

\subsection{1) Retardo Mental ligado ao cromossomo $X$}

O retardo mental (RM) é uma das doenças neurológicas com maior prevalência, afetando cerca de $3 \%$ da população mundial, e pode ser definido como um atraso no desenvolvimento das funções cognitivas e um nível de inteligência abaixo do normal (Chiurazzi et al., 2001). Como muitas das doenças neurológicas, o RM é uma doença heterogênea que pode ser causada por alterações genéticas, ambientais, ou uma combinação de ambas.

Muitos dos casos de RM são atribuídos a fatores genéticos, podendo ser causados tanto por mutações nos cromossomos autossomos como no cromossomo X. Cerca de $10 \%$ dos casos de RM são relacionados a mutações em genes no cromossomo X, denominados de RM ligado ao X (RM-LX) (Stevenson et al., 2002). Essas mutações se tornam mais evidentes em indivíduos do sexo masculino (hemizigotos), pois não podem compensar mutações deletérias em genes do cromossomo $\mathrm{X}$ como ocorre em muitas mulheres heterozigotoas para mutações patogênicas em genes localizados no cromossomo $\mathrm{X}$ (devido ao processo de inativação preferencial do cromossomo $\mathrm{X}$ contendo a alelo deletério).

Como o RM em geral, o RM-LX é subdividido em sindrômico e nãosindrômico. O RM-LX sindrômico (RMS-LX) é aquele no qual existe um padrão específico de anormalidades físicas, neurológicas ou metabólicas associadas com o retardo mental. Já no RM-LX não-sindrômico (RMNS-LX) as deficiências das funções cognitivas não estão associadas com outros problemas dismórficos, neurológicos ou metabólicos. Aproximadamente dois terços dos casos de RM-LX são considerados não-sindrômicos, porém à medida que estudos clínicos, bioquímicos e moleculares estão se aprimorando, a proporção de casos sindrômicos vem aumentando com uma concomitante diminuição dos casos não-sindrômicos.

Aproximadamente $40 \%$ dos 885 genes codificadores de proteínas identificados no cromossomo X humano são expressos no cérebro e, em princípio, o RM-LX pode ser causado por mutações em qualquer um desses genes (Ropers \& Hamel, 2005). Até o momento cerca de 140 formas de RMS-LX foram descritas, das quais 69 já tiveram o defeito genético identificado e 50 outras tiveram o defeito genético mapeado em uma região específica do cromossomo X. Já para as formas de RMNS-LX, 33 formas 
tiveram os defeitos genéticos identificados e 54 outras tiveram o defeito genético mapeado (Schwartz \& Stevenson, 2008). Os genes relacionados ao RM-LX, como ao RM em geral, codificam proteínas que se encontram agrupadas em distintas subclasses funcionais, tais como: enzimas (exemplos constituem CDKL5, SMS, RSK2, MAOA); fatores de transcrição e de remodelamento de cromatina (exemplos constituem $A R X$, PHF6, SOX3 e JARID1C); proteínas transmembranas (exemplos constituem SLC16A2 e SLC6A8); proteínas associadas a filamentos de actina e microtúbulos (exemplos constituem FLNA e $D C X$ ) e proteínas reguladoras e/ou efetoras da via de sinalização das proteínas Rho-like GTPases (exemplos constituem OPHN1, PAK3, ARHGEF6, TM4SF2 e FGD1) (revisado em Ropers \& Hamel, 2005; Chelly et al., 2006 e Vaillend et al., 2008).

Neste trabalho empregamos diferentes estratégias para o estudo de dois genes associados com formas de retardo mental sindrômico ligados ao cromossomo X: o gene SMS (Capítulo 3) e o gene ARHGEF9 (Capítulo 4).

\subsection{2) Hiperecplexia}

Hiperecplexia (OMIM \#149400), também conhecida como "Doença do Susto" ou "Síndrome da Pessoa Rígida", é uma desordem neuronal rara, com prevalência ainda desconhecida, caracterizada por uma resposta exagerada ao susto, hipertonia neonatal, e convulsões mioclônicas noturnas (Zhou et al., 2002). Recém nascidos com hiperecplexia manifestam hipertonia difusa, hiperreflexia, e resposta exagerada de susto ao barulho e ao manuseio após o nascimento. O "ataque de susto" (levando a uma resposta súbita de retração da cabeça e flexões tônicas do corpo) pode ser facilmente observado por um leve toque no nariz de um indivíduo afetado ("nose tapping"). Adultos com hiperecplexia, que não foram tratados com drogas para controlar os ataques, podem ser gravemente debilitados e, eventualmente, se locomoverem apenas em cadeira de rodas (Andermann et al., 1980; Suhren et al., 1966).

A hiperecplexia está associada principalmente a mutações patogênicas no gene codificador da subunidade $\alpha 1$ do receptor de glicina (GLRA1) (Shiang et al., 1993; Rees et al., 2002) e, mais recentemente, no gene codificador do transportador présináptico de glicina (GlyT2) (SLC6A5) (Rees et al., 2006). Ambas as mutações ocorrem tanto em formas famílias como em formas esporádicas da doença. Ainda, em 
casos esporádicos foram descritos mutações nos genes codificadores da subunidade $\beta$ do receptor de glicina (GLRB) (Rees et al., 2002), da proteína gefirina (GPHN) (Rees et al., 2003), e da proteína colibistina (ARHGEF9) (Harvey et al., 2004). Todos os genes associados com hiperecplexia estão relacionados com neurotransmissão inibitória no $\mathrm{SNC}$ e alguns estudos funcionais sugerem que a maioria das mutações encontradas nos pacientes levam à diminuição ou perda de função das proteínas mutadas (Lynch et al., 1997; Zhou et al., 2002; Rees et al., 2003; Rees et al., 2006).

Segundo a literatura, uma porção significativa de pacientes com hiperecplexia não apresenta mutações em nenhum dos genes acima descritos, o que sugere que mutações em outras regiões ainda não analisadas desses genes (como regiões regulatórias) ou mutações em outros genes estejam envolvidas na etiologia dessa doença (Shiang et al., 1995; Vergouwe et al., 1997; Rees et al., 2001; Rees et al., 2002; Rees et al., 2003; Harvey et al., 2004).

Assim sendo, conforme descrito mais adiante (Capítulo 4), consideramos o gene ARHGEF9 (que codifica a proteína colibistina, envolvida na formanção e funcionamento das sinapses inibitórias) um bom candidato para a etiologia de hiperecplexia.

\subsection{3) Epilepsia idiopática}

Epilepsia é uma desordem neurológica caracterizada por crises espontâneas e recorrentes, afetando $1 \%$ a $3 \%$ da população mundial (Gitai et al., 2008). As crises epilépticas refletem uma atividade elétrica anormal no SNC, que podem ser focalizadas ou generalizadas. $\mathrm{O}$ aumento exarcebado de excitação ou diminuição excessiva de inibição nos neurônios pode resultar em episódios epiléticos.

A natureza do distúrbio epiléptico é essencial para a classificação das epilepsias. Neste sentido, as epilepsias generalizadas e focalizadas têm sido classificadas em sintomáticas ou idiopáticas. As epilepsias sintomáticas são aquelas em que é possível a detecção de lesões anatômicas ou histológicas no encéfalo, como nos casos de malformações e neoplasias. Já nas epilepsias idiopáticas o processo epiléptico não é atribuído a nenhuma alteração estrutural ou histológica no encéfalo ou outro sinal ou sintoma neurológico (Engel, 2001).

As epilepsias idiopáticas correspondem a $40 \%$ das epilepsias e hoje é sabido

que a maioria é consequiência de alterações genéticas. Essa forma de epilepsia tem 
geralmente padrão de herança multifatorial (resultando de interações entre genes de susceptibilidade e fatores ambientais) e os genes de susceptibilidade são, em sua grande maioria, desconhecidos. Contudo, a análise molecular de famílias grandes com vários membros afetados tem auxiliado na identificação de genes associados a várias formas monogênicas da doença (Kaneko et al., 2002). Até o momento foram identificados 11 diferentes genes que atuam como causa primária dessas formas de epilepsias (Tabela 2). Uma vez que quase todos esses genes codificam subunidades de canais iônicos moduladores da atividade neural, têm-se referido a esse grupo de epilepsias como canalopatias (Noebels, 2003). Os canais envolvidos nas epilepsias idiopáticas monogênicas pertencem à classe de canais voltagem-dependentes, que são importantes para geração e controle do potencial de ação, ou à classe dos canais ligantes-dependentes, que estão envolvidos principalmente com a transmissão sináptica. As mutações identificadas nesses genes induzem as crises epiléticas, provavelmente, por mecanismos que levam a uma facilitação dos estímulos excitatórios ou um impedimento das vias inibitórias.

Tabela 2. Genes associados a diferentes tipos de epilepsias idiopáticas.

\begin{tabular}{|c|l|l|}
\hline $\begin{array}{c}\text { Gene } \\
\text { mutado }\end{array}$ & \multicolumn{1}{|c|}{ Proteína } & \multicolumn{1}{c|}{ Referências } \\
\hline$C L C N 2$ & Canal de cloreto ClC-2 & Haug et al., 2003 \\
\hline$K C N A 1$ & $\begin{array}{l}\text { Membro } 1 \text { da subfamília shaker-related de canais de } \\
\mathrm{K}^{+}\end{array}$ & Eunson et al., 2000 \\
\hline$K C N Q 2$ & Membro 2 da subfamilia Q de canais de $\mathrm{K}^{+}$ & Singh et al., 1998 \\
\hline$K C N Q 3$ & Membro 3 da subfamilia Q de canais de $\mathrm{K}^{+}$ & Charlier et al., 1998 \\
\hline$S C N 1 A$ & Subunidade $\alpha 1$ do canal de $\mathrm{Na}^{+}$ & Escayg et al., 2000 \\
\hline$S C N 1 B$ & Subunidade $\beta 1$ do canal de $\mathrm{Na}^{+}$ & Wallace et al., 1998 \\
\hline$S C N 2 A$ & Subunidade $\alpha 2$ do canal de $\mathrm{Na}^{+}$ & Haug et al., 2001 \\
\hline$G A B R A 1$ & Subunidade $\alpha 1$ do receptor $\mathrm{GABA} \mathrm{A}$ & Maljevic el al., 2006 \\
\hline$G A B R G 2$ & Subunidade $\gamma 2$ do receptor GABA $\mathrm{GA}$ & Baulac et al., 2001 \\
\hline$C H R N A 4$ & Subunidade $\alpha 4$ do receptor nicotínico de acetilcolina & Beck et al., 1994 \\
\hline$C H R N B 2$ & Subunidade $\beta 2$ do receptor nicotínico de acetilcolina & De Fusco et al., 2000 \\
\hline
\end{tabular}

Conforme discutido em detalhes mais adiante, neste trabalho analisamos o gene ARHGEF9 (que codifica a proteína colibistina, envolvida na formação e 
funcionamento das sinapses inibitórias), em pacientes com retardo mental associado à epilepsia (Capítulo 4).

\section{5) Proteína colibistina}

\subsection{1) Caracterização}

A proteína colibistina (collybistin) humana, conhecida também como hPEM-2 - proteína humana homóloga à proteína Posterior End Mark-2 (envolvida na polarização de embriões de Ascidian Ciona savignyi) (Reid et al., 1999), foi inicialmente identificada no projeto de seqüenciamento realizado por Ishikawa et al. (1997) como KIAA0424.

O gene humano que codifica a proteína colibistina é denominado ARHGEF9 e está mapeado no cromossomo Xq11.2, apresentando 11 exons distribuídos em aproximadamente $190 \mathrm{~kb}$ de DNA genômico (Reid et al., 1999). A análise de ESTs (expression sequence tags) de ARHGEF9 presentes em bancos de dados públicos da internet mostrou que este gene é transcrito em duas isoformas diferindo apenas quanto à presença dos exons 1a e 1b, onde o exon 1a codifica uma seqüência de resíduos de aminoácidos maior na região N-terminal da proteína (resíduos MQWIRGGSGM) do que o exon $1 b$, que codifica uma seqüência de resíduos de aminoácidos menor na região N-terminal (resíduos MTL). A presença desses dois exons sugere que o ARHGEF9 apresenta dois promotores que podem controlar a expressão gênica de forma tecido-específica e/ou em diferentes estágios do desenvolvimento (Harvey et al., 2004).

O uso alternativo dos exons 1a ou 1b de ARHGEF9 não influencia no uso dos exons 2-10 do gene, os quais estão presentes em ambas as isoformas. Tais isoformas codificam proteínas (com 523 e 516 resíduos de aminoácidos respectivamente) constituídas pelo domínio SH3 (src homology 3) na região N-terminal, seguido pelos domínios DH (dbl homology) e PH (pleckestrin homology) na região central e uma sequiência rica em resíduos de prolina (denominada coiled-coil ou $\mathrm{CC}$ ) na porção Cterminal (Reid et al., 1999; Harvey et al., 2004) (Figura 3D). Os domínios SH3 e CC estão envolvidos em interações proteína-proteína e os domínio DH e PH são característicos de proteínas da superfamília das GEFs (guanine nucleotide exchange factors), a qual a colibistina faz parte (Lemmon \& Ferguson, 2000). 


\subsection{2) A proteína colibistina tem atividade de GEF sobre proteínas da família das Rho-like GTPases}

As proteínas Rho-like GTPases, guanosinas trifosfatases semelhantes a Rho, são capazes de ligar e hidrolisar GTP (Bourne et al., 1990). Em mamíferos, são conhecidos 21 membros da família Rho-like GTPase: Rho (A, B e C), Rac (1, 2 e 3), Cdc42, RhoD, RhoG, RhoH/TTF, RhoBTB (1, 2), TC10, TCL, Rnd (1, 2 e 3), Rif, Chp (1, 2) e Wrch (Negishi \& Katoh, 2002; Etienne-Manneville \& Hall, 2002; Wherlock \& Mellor, 2002). Dentre esses, as proteínas melhores caracterizadas são RhoA (Ras homologous member A), Rac1 (Ras-related C3 botulinum toxin substrate 1) e Cdc42 (cell division cycle 42).

As Rho-like GTPases atuam como interruptores moleculares por alternarem entre um estado ativo (quando ligadas a molécula de GTP) e inativo (quando ligadas a molécula de GDP). A ativação das Rho-like GTPases requer a retirada da molécula de GDP da alça de ligação do nucleotídeo e subsequiente substituição por uma molécula de GTP, reação essa catalisada por proteínas GEFs. Já a desativação das Rho-like GTPases é mediada por proteínas GAPs (GTPases-activated protein) que estimulam a atividade GTPase intrínsica das Rho-like GTPases, resultando na substituição de GTP por GDP. No estado desativado, proteínas denominadas GDI (GDP dissociation inhibitors) estabilizam a ligação das Rho-like GTPases ao GDP e as seqüestram para o citoplasma (Boettner \& Aelst, 2002) (Figura 4).

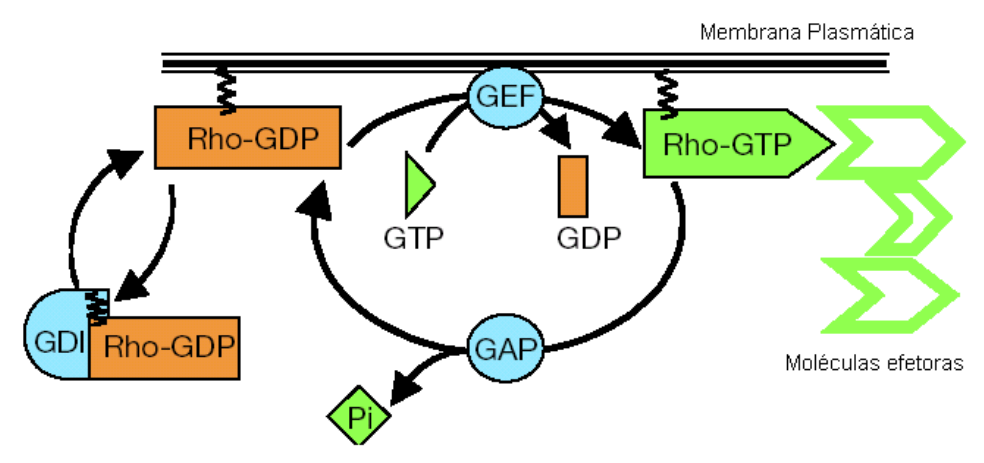

Figura 4. Esquema da via de ativação e desativação das Rho-like GTPases. GEF: guanine nucleotide exchange factors; GAP: GTPases-activated protein e GDI: GDP dissociation inhibitors. Uma vez ativada (ligada ao GTP), as Rho-like GTPases ativam outras moléculas efetoras que desencadeiam diversos processos celulares. 
Quando ativadas, as Rho-like GTPases controlam a organização do citoesqueleto e estão envolvidas em vários processos celulares que incluem migração, adesão, polarização, direcionamento de axônios e organização e funcionamento das sinapses (Luo et al., 1997; Luo, 2000). As Rho-like GTPases ativadas influenciam na sinalização de outras vias por intermédio de proteínas efetoras como as MAP (mitogen-activating protein) quinases JNK e p38 (Mielke \& Herdegen, 2000) e PAK (p21-activated kinases) (Daniels \& Bokoch, 1999).

A colibistina é uma proteína GEF da família Dbl (B-cell lymphoma-like). A principal característica das proteínas GEF da família Dbl são os domínios DH e PH. O domínio $\mathrm{DH}$, com aproximadamente 150 resíduos de aminoácidos, exerce a reação de troca do GDP pelo GTP. Já o domínio PH, composto por aproximadamente 100 resíduos de aminoácidos, liga-se com grande afinidade aos fosfoinositídeos PI3P/PtdIns-3-P da membrana plasmática, e é importante para a localização das GEFs junto à membrana (Cerione \& Zheng, 1996; Lemmon \& Ferguson, 2000).

Em fibroblastos a proteína colibistina humana está especificamente envolvida na ativação da GTPase Cdc42, a qual tem influência na morfologia celular por induzir polimerização dos filamentos de actina e formação de protusões denominadas filopódios (Reid et al., 1999).

\subsection{3) Papel da colibistina na sinaptogênese inibitória do SNC}

Em 2000, Kins et al. utilizando o sistema de duplo-híbrido em levedura para identificar proteínas que interagem com gefirina (gephyrin), uma proteína presente em sítios pós-sinápticos inibitórios, identificaram a proteína colibistina.

Nas sinapses inibitórias a proteína gefirina desempenha papel fundamental no agrupamento de receptores de glicina e de certos subtipos de receptores $\mathrm{GABA}_{\mathrm{A}}$ (compostos pelas subunidades $\alpha 2$ e $\gamma$ ) (Kneussel \& Betz, 2000). Glicina e GABA $(\gamma$ aminobutyric acid) são importantes neurotransmissores inibidores do SNC. Os receptores de glicina e $\mathrm{GABA}_{\mathrm{A}}$ são receptores ionotrópicos, formados por pentâmeros de subunidades protéicas: receptores $\mathrm{GABA}_{\mathrm{A}}$ são compostos por duas subunidades $\alpha$, duas $\beta$ e uma $\gamma$; receptores de glicina geralmente apresentam três subunidades $\alpha$ e

duas $\beta$. Tais receptores atuam como canais permeáveis a íons cloro, cujo influxo produz potenciais pós-sinápticos hiperpolarizantes inibidores (isto é, que diminuem a probabilidade de disparo de um potencial de ação pelo neurônio). O agrupamento 
desses receptores na membrana das células nervosas parece ser mediados pela interação de gefirina com diferentes proteínas reguladoras ou constituintes do citoesqueleto como tubulina (Kirsch et al., 1991), profilina (Mammoto et al., 1998), cadeias leves de dineína 1 e 2 (Fuhrmann et al., 2002) e Mena/VASP (Giesemann et al., 2003).

Kins et al. (2000) descreveram inicialmente duas isoformas de colibistina em rato - colibistina 1 e 2 . A isoforma maior, colibistina 1, apresenta 493 resíduos de aminoácidos que contêm os domínios SH3, DH, PH e CC (Figura 5A); a isoforma menor, colibistina 2, apresenta 413 resíduos de aminoácido que contêm apenas os domínios DH e PH (Figura 5B). As colibistinas 1 e 2 interagem com a proteína gefirina por meio de uma sequiência localizada entre os domínios SH3 e DH, a qual está presente em ambas as isoformas, e apresenta $100 \%$ de identidade entre rato, camundongo e homem (Kins et al., 2000; Grosskreutz et al., 2001). Ainda, a homologia total entre a proteína colibistina 1 de rato e a proteína colibistina humana é de $93 \%$.

Kins et al. (2000) demonstraram que quando super-expressas em células humanas em cultura (células HEK 293), colibistina 1 e 2 de rato se distribuem por todo o citoplasma. Por outro lado, quando super-expressa nessas mesmas células, a proteína gefirina de rato forma grandes agregados intracelulares. Co-expressão de colibistina 1 com gefirina induz a redistribuição de colibistina 1 para os depósitos intracelulares de gefirina. Co-expressão de colibistina 2 e gefirina resulta na translocação dos agregados intracelulares de gefirina para junto da membrana plasmática, e este complexo é capaz de recrutar a subunidade $\beta$ dos receptores de glicina para junto da membrana. Portanto, esses resultados sugeriram que colibistina 2 (sem os domínios SH3 e CC) parece ser importante para a localização de gefirina e de receptores de glicina junto da membrana plasmática. Os autores sugeriram que colibistina 2 deveria desempenhar um papel importante nas cascatas de sinalização que promovem rearranjo do citoesqueleto celular, agrupamento e recrutamento de gefirina e, conseqüentemente, de receptores de glicina e também receptores $\mathrm{GABA}_{\mathrm{A}}$ para sítios pós-sinápticos inibidores (Kins et al., 2000) (Figura 6). Ainda, os domínios $\mathrm{SH} 3$ e/ou CC parecem regular negativamente a habilidade de colibistina 1 translocar gefirina para regiões junto à membrana plasmática. 


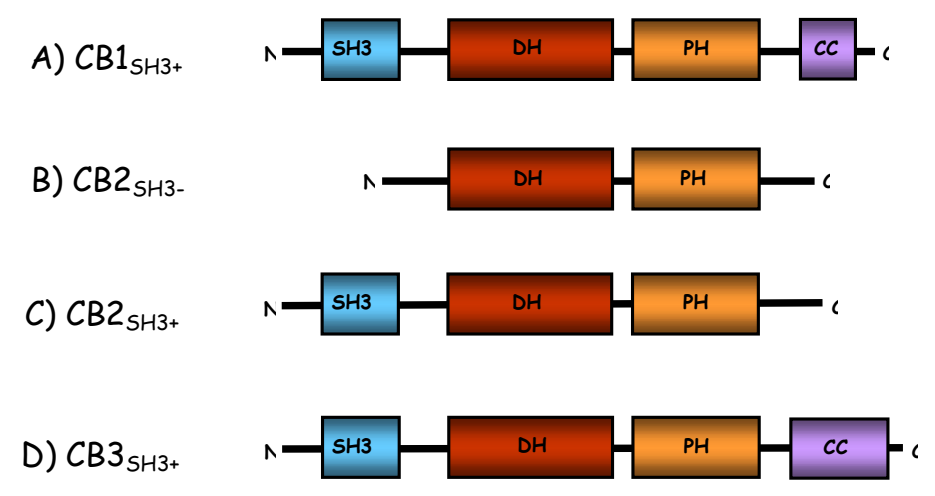

Figura 5. Representação das isoformas da proteína colibistina que são expressas em encéfalo de rato e camundongo. Em encéfalo humano, apenas a isoforma $\mathrm{CB} 3_{\mathrm{SH} 3+}$ é expressa.

Mais recentemente, Harvey et al. (2004) identificaram por experimentos de RT-PCR em encéfalo total e espinha dorsal de rato mais duas isoformas da proteína colibistina (Figuras 5C e 5D). Os autores renomearam as isoformas como: CB1 (colibistina 1), CB2 (colibistina 2), e CB3 (similar a isoforma humana). Eles também identificaram nas isoformas a presença ou ausência do domínio SH3 $\left(\mathrm{CB} 1_{\mathrm{SH} 3+}\right.$, $\mathrm{CB} 2_{\mathrm{SH} 3+}, \mathrm{CB} 2_{\mathrm{SH}_{3}-}$ e $\mathrm{CB} 3_{\mathrm{SH} 3+}$ ) (Figura 5). Os autores verificaram que as isoformas $\mathrm{CB} 2_{\mathrm{SH} 3+}$ e $\mathrm{CB} 3_{\mathrm{SH} 3+}$ são predominantemente expressas em cérebro total e espinha dorsal de rato. Já em humanos, apenas expressão da isoforma $\mathrm{CB}_{\mathrm{SH}_{3+}}$ foi identificada em encéfalo e espinha dorsal.

Esses autores também realizaram estudos de super-expressão das diferentes isoformas da colibistina de rato e da proteína gefirina em células HEK 293 e comprovaram os resultados anteriormente observados por Kins et al. (2000): apenas a isoforma menor de colibistina, sem os domínios $\mathrm{SH} 3$ e $\mathrm{CC}$ (CB2 $\left.{ }_{\mathrm{SH} 3-}\right)$, é capaz de promover a formação de agrupamentos de gefirina junto à membrana plasmática, e que agregados de $\mathrm{CB} 2_{\mathrm{SH} 3}$ /gefirina são capazes de recrutar receptores de glicina heteroméricos (compostos por subunidades $\alpha$ e $\beta$ ) para a membrana. Ainda, em outros experimentos, os autores super-expressaram as proteínas colibistinas $\mathrm{CB} 2{ }_{\mathrm{SH} 3+}$ e $\mathrm{CB} 2_{\mathrm{SH} 3}$ - em neurônios corticais de camundongos em cultura para analisar a influência dessas proteínas sobre a gefirina expressa endógenamente nas células. Foi observado que a super-expressão de ambas as isoformas da colibistina não influencia na localização da gefirina endógena das células. Porém, quando esses autores super- 
expressaram em neurônios corticais em cultura uma proteína colibistina $\mathrm{CB} 2_{\mathrm{SH} 3}$ mutante sem o domínio $\mathrm{PH}$, os agrupamentos de gefirina nos dendritos foram quase completamente eliminados, sugerindo que essa proteína mutante adquire um efeito dominante negativo e compete com a proteína colibistina endógena na sua capacidade de se ligar a gefirina. Esses resultados sugerem a importânica do domínio PH na localização de colibistina e gefirina nos dendritos.

Além da gefirina não são conhecidas outras proteínas que interagem com colibistina e nem o seu modo de regulação.

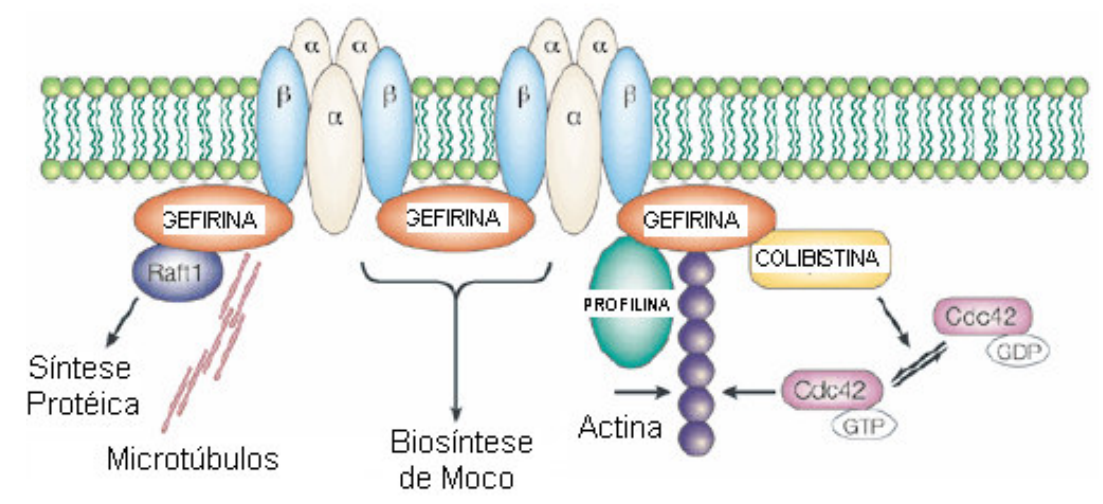

Figura 6. Vias de interação entre proteínas citoplasmáticas para o agrupamento dos receptores de neurotransmissores de glicina e GABA nas membranas dos sítios póssinápticos inibidores. Nesta figura estão representados apenas os receptores de glicina, os quais são formados por três subunidades $\alpha$ e duas $\beta$.

\subsection{4) Localização e expressão de colibistina}

Por experimentos de hibridização in situ, Kneussel et al. (2001) estudaram a expressão do gene da colibistina em camundongos tanto durante o desenvolvimento embrionário como na fase adulta. Utilizando uma sonda comum a todas as isoformas de colibistina e uma sonda específica para as isoformas com o domínio SH3, os autores verificaram expressão das variantes de colibistina apenas em tecidos neuronais em todos os estágios do desenvolvimento embrionário analisados (a partir de E13). No córtex cerebral em desenvolvimento, expressão é detectada apenas em neurônios na fase pós-mitótica, a partir de E14. Em animais adultos, expressão é observada uniformemente por todas as estruturas corticais. No cerebelo na fase E18, 
as camadas de células de Purkinje expressam as isoformas de colibistina; na fase adulta, altos níveis de expressão são detectados em todos os tipos de neurônios das camadas de células de Purkinje, de células granulares internas e nas células da camada molecular. Esses resultados revelam expressão de colibistina em neurônios em diferenciação. Na espinha dorsal, baixos níveis dos transcritos são observados inicialmente a partir de E12 nas regiões ventrais que contém motoneurônios em diferenciação. Em E13, níveis mais altos de expressão são observados ao longo de toda espinha dorsal. Nesse estágio do desenvolvimento, transcritos são detectados também nos glânglios da raiz dorsal. O nível mais alto de expressão de colibistina no SNC de camundongo adulto é observado no hipocampo (o qual está envolvido nos processos de aprendizagem e memória). Os transcritos de colibistina estavam fortemente expressos em distintas sub-regiões: CA1, CA3 e no giro dentado. Notavelmente, essas regiões também expressam altos níveis dos transcritos de gefirina (Kirsch et al., 1993) e de diferentes subunidades do receptor $\mathrm{GABA}_{\mathrm{A}}(\alpha 1, \alpha 2$, $\alpha 3, \alpha 4, \alpha 5, \beta 1, \beta 2, \beta 3, \gamma 2$ e $\delta$ ) (Wisden et al., 1992). Transcritos também são abundantes no bulbo olfativo de camundongo adulto (Kneussel et al., 2001).

Esses resultados indicam que a expressão de colibistina no SNC de camundongo correlaciona-se com o período de diferenciação neuronal e sinaptogênese.

Os autores também analisaram a expressão de colibistina durante certos períodos do desenvolvimento embrionário de camundongos por experimentos de Northern blot. Utilizando uma sonda complementar ao domínio DH de colibistina (comum a todas as isoformas), eles verificaram que no período embrionário E3,5 colibistina ainda não é expressa, porém em E7 começam a ser detectados moderados níveis de expressão, que aumentam significantemente no período E11. Já em E15 e E17, os níveis de expressão foram similares, sugerindo que o platô de expressão da colibistina ocorre durante a segunda metade do desenvolvimento embrionário do camundongo. Os autores compararam os níveis de transcritos de gefirina e da subunidade $\beta$ dos receptores de glicina com os níveis de colibistina durante o desenvolvimento embrionário por experimentos de Northern blot. Eles verificaram que os transcritos da gefirina já são expressos em E3, porém os transcritos da subunidade $\beta$ dos receptores de glicina só são expressos a partir de E11. Esses dados 
mostram que os transcritos de colibistina são detectados antes dos transcritos da subunidade $\beta$ dos receptores de glicina, o que é consistente com a proposta de que a colibistina controla o processo de ancoramento dos receptores de glicina nos neurônios. Já a expressão precoce dos transcritos da gefirina provavelmente reflete sua ubíqua função no metabolismo celular (Feng et al., 1998; Stallmeyer et al., 1999), pois além de ser uma molécula essencial para o agrupamento de receptores de glicina e certos subtipos de receptores $\mathrm{GABA}_{\mathrm{A}}$ nas membranas pós-sinápticas inibitórias, ela participa de outros processos celulares essenciais, como da biosíntese do cofator de molibdênio (MoCo) (Feng et al., 1998) e provavelmente da tradução de proteínas, por interagir também com mTOR (mammalian target of rapamycin), uma quinase envolvida no controle do início da tradução em eucariotos (Sabatini et al., 1999).

\subsection{5) Modelos animais para o estudo da colibistina}

Recentemente, Papadopoulos et al. (2007) descreveram camundongos nocautes constitutivos para o gene da colibistina. As dimensões e morfologias dos encéfalos desses camundongos nocautes estavam normais. Experimentos de Western blot também revelaram expressão normal (semelhante à observada nos camundongos selvagens) da proteína gefirina, de receptores $\mathrm{GABA}_{\mathrm{A}}$ (compostos pela subunidade $\gamma 2$ ) e de receptores de glicina (compostos pela subunidade $\alpha$ ) em direntes regiões do sistema nervoso central dos camundongos adultos. Entretanto, a análise da localização da proteína gefirina e de receptores $\mathrm{GABA}_{\mathrm{A}}$ e de glicina por imunofluorescência em cortes dos cérebros dos camundongos nocautes adultos revelou que os agrupamentos de gefirina estavam muito reduzidos nas membranas pós-sinápticas dos neurônios do hipocampo, amígdala, partes do tálamo e cerebelo. Ainda, os camundongos nocautes adultos apresentavam também drástica redução dos agrupamentos de receptores $\mathrm{GABA}_{\mathrm{A}}$ na membrana de neurônios da amígdala basolateral e do hipocampo. Essas alterações ocasionaram redução da transmissão gabaérgica, alteração da plasticidade sináptica, diminuição do aprendizado espacial e do comportamento exploratório e aumento da ansiedade.

Curiosamente os camundongos nocautes possuíam os receptores de glicina normalmente localizados e agrupados nas membranas dos sítios pós-sinápticos inibitórios. Esse resultado não era esperado, pois além da gefirina ser essencial para o agrupamento dos receptores de $\mathrm{GABA}_{\mathrm{A}}$, ela também é essencial para o agrupamento 
de receptores de glicina (Kneussel \& Betz, 2000). Uma vez que a gefirina não estava corretamente agrupada na membrana dos neurônios, deve existir outro mecanismo ainda desconhecido que promove o ancoramento correto dos receptores de glicina na membrana desses neurônios.

Mais recentemente, Papadopoulos et al. (2008) descreveram novos camundongos deficientes para colibistina, os quais apresentavam o gene da colibistina nocauteado apenas no prosencéfalo em diferentes estágios do desenvolvimento (tanto no período embrionário como na fase adulta - até a terceira semana pós-natal). Supressão da expressão de colibistina nos diferentes períodos de vida observados reproduziu os mesmos defeitos no agrupamento de gefirina e dos receptores $\mathrm{GABA}_{\mathrm{A}}$ (subunidade $\gamma 2$ ) observados nos camundongos adultos nocautes constitutivos para o gene da colibistina: acúmulo de gefirina no citoplasma das células neuronais e perda dos agrupamentos de gefirina e de receptores $\mathrm{GABA}_{\mathrm{A}}$ nos sítios pós-sinápticos do hipocampo. Os dados deste último trabalho demonstram que a proteína colibistina é necessária tanto para a localização inicial (durante os estágios iniciais da sinaptogênese) quanto para a manutenção de gefirina e de receptores de $\mathrm{GABA}_{\mathrm{A}}$ nas membranas pós-sinápticas inibitórias do hipocampo de camundongos.

\subsection{6) Mutações no gene $A R H G E F 9$ foram descritas em pacientes com diferentes doenças neurológicas}

A confirmação da importância da proteína colibistina na localização póssináptica de gefirina e de receptores de neurotransmissores inibitórios em humanos veio com a identificação de três mutações patogênicas no gene ARHGEF9.

Em 2004, Harvey et al. identificaram uma mutação de substituição de aminoácido (p.G55A) no domínio SH3 da colibistina em um paciente com hiperecplexia associada à epilepsia de difícil controle e retardo mental grave, que faleceu com 4 anos de idade. Estudos funcionais reveleram que a proteína colibistina humana mutada, mais não a proteína selvagem, super-expressa em neurônios corticais de camundongos adultos in vitro forma agregados intracelulares com a proteína gefirina e com receptores de $\mathrm{GABA}_{\mathrm{A}}$, impedindo o trasporte dessas proteínas para os dendritos.

Em 2008, Marco et al. descreveram uma paciente com uma inversão paracêntrica no cromossomo X (46, X, inv (X) (q11.1q27.3)), onde um dos pontos de 
quebra ocorreu no gene ARHGEF9 (entre os exons 1 e 3) e o outro em um deserto gênico. Estudos de inativação do cromossomo $X$ em células sanguíneas da paciente reveleram que ela apresenta inativação completa do cromossomo X normal. O quadro clínico da paciente consiste em retardo mental moderado e hiperestimulação sensorial. Análise dos níveis de expressão de $A R H G E F 9$ em células sanguíneas da paciente revelou uma diminuição da expressão do gene ARHGEF9 de cerca de dez vezes em relação aos de controles, e os autores sugeriram que a pequena expressão encontrada na paciente é proveniente do cromossomo X normal, apesar dele ser preferencialmente inativado. Assim sendo, o mecanismo molecular dessa mutação parece ser de perda de função.

Mais recentemente, Kalscheuer et al. (2008) descreveram uma paciente com uma translocação balanceada entre os cromossomos X e 18 (46,X,t $(X ; 18)$ (q11.1;q11.21)), onde o ponto de quebra no cromossomo $\mathrm{X}$ ocorreu sobre o gene ARHGEF9 (entre os exons 6 e 7), e o ponto de quebra no cromossomo 18 ocorreu em uma região que não possui gene conhecido ou predito. A paciente apresenta retardo mental profundo, epilepsia, dismorfismo facial, ansiedade, insônia e comportamento de agressividade. Estudos de expressão do gene ARHGEF9 em células sanguíneas da paciente revelaram ausência de transcritos normais do gene, sugerindo que a paciente apresenta inativação completa do cromossomo X normal. Por outro lado, os autores verificaram que a paciente apresenta duas classes de RNA mensageiros truncados sendo expressos em suas células (compostos pelos exons 1 a 6 de ARHGEF9, seguidos por exons crípticos derivados de sequências intrônicas ou intergênicas dos cromossomos X e 18), e conseqüentemente a expressão de duas colibistinas truncadas sem o domínio PH e a região C-terminal. Em neurônios corticais de camundongos em cultura a super-expressão das duas colibistinas humanas truncadas, mas não da proteína humana selvagem, resultou na diminuição drástica de agrupamentos das proteínas gefirina e de receptores $\mathrm{GABA}_{\mathrm{A}}$ endógenos nas regiões de sinapse.

É interessante comentar que, conforme discutido por Kalscheuer et al. (2008), os fenótipos mais graves em humanos são observados quando as proteínas colibistinas mutadas parecem adquirir um efeito de ganho de função, seqüestrando a gefirina e os receptores $\mathrm{GABA}_{\mathrm{A}}$ endógenos das membranas dos sítios pós-sinápticos inibitórios (Harvey et al., 2004; Kalscheuer et al., 2008). 
Conforme descrito anteriormente, neste trabalho analisamos o gene ARHGEF9 em pacientes com hiperecplexia e em pacientes com retardo mental associado com epilepsia (Capítulo 4). Ainda, com a finalidade de aumentar nosso conhecimento sobre as vias de sinalização em que a proteína colibistina está envolvida, nós realizamos um estudo funcional com a proteína colibistina humana com o objetivo de identificar outras proteínas que interagem com ela (Capítulo 5). 


\section{6) Objetivos}

Os objetivos do presente trabalho são:

1) Identificar o gene associado com uma forma de Retardo Mental sindrômico com herança recessiva ligada ao cromossomo X (Capítulo 3).

2) Analisar a região codificadora do gene ARHGEF9 em pacientes com hiperecplexia e retardo mental associado com epilepsia (Capítulo 4).

3) Identificar proteínas que interagem com colibistina, com a finalidade de maior compreensão das cascatas de sinalização envolvidas na formação e funcionamento de sinapses inibitórias do sistema nervoso central (Capítulo 5). 


\section{Capítulo 2}

\section{Casuística e Métodos}

\section{1) Casuística}

\subsection{1) Pacientes}

Neste trabalho foram estudados pacientes com três doenças neurológicas etiológicamente e/ou clinicamente distintas:

- uma família com uma forma de Retardo Mental sindrômico com herança recessiva ligada ao cromossomo X (síndrome de Snyder-Robinson): amostra constituída por 34 indivíduos, dos quais 3 meninos são afetados. Todas as mulheres da família são fenotipicamente normais. Esta família foi encaminhada para diagnóstico molecular e aconselhamento genético no Centro de Estudos do Genoma Humano (CEGH), Instituto de Biociências, Universidade de São Paulo (Capítulo 3);

- pacientes portadores de hiperecplexia: amostra constituída por 6 indivíduos afetados (quatro meninos com idades entre 4 a 6 anos e duas meninas com idades de 2 e 10 anos). Esses pacientes foram encaminhados para estudo molecular no CEGH, ou tiveram suas amostras de sangue enviadas pelo correio pelos Doutores Fernando Kok e Erasmo Barbante Casella (Hospital das Clínicas da Faculdade de Medicina da Universidade de São Paulo - HC-FMUSP) (Capítulo 4);

- pacientes portadores de retardo mental associado com epilepsia: amostra constituída por 22 indivíduos afetados, todos do sexo masculino. Amostras de sangue periférico ou de DNA genômico desses pacientes foram encaminhadas pelas Doutoras Iscia Lopes (Universidade de Campinas - UNICAMP) e Maria Luiza Giraldes de Manreza (HC-FMUSP) (Capítulo 4). 


\subsection{2) Controles}

Duas amostras de controles foram estudadas neste trabalho, ambas no Capítulo 3:

- Amostra 1: 270 DNAs genômicos de indivíduos controles caucasóides (132 homens e 138 mulheres) que fazem parte de uma amostra de aproximadamente 1000 indivíduos, constituída em um projeto conjunto de alguns grupos de pesquisa do CEGH. A amostra é caracterizada por doadores do Hemocentro do Hospital das Clínicas de São Paulo, com idades e raças variáveis. Esse projeto foi aprovado pela Comissão de Ética para análise de projetos de pesquisa do Hospital de Clínicas e da Faculdade de Medicina da Universidade de São Paulo em 26/06/2001 (protocolo 349/01);

- Amostra 2: 316 DNAs genômicos de indivíduos controles caucasóides do sexo masculino da população Norte-Americana cedidas pelo Centro de Genética de Greenwood (Greenwood Genetics Center), localizado na cidade de Greenwood, na Carolina do Sul (EUA).

\subsection{3) Considerações gerais}

Todos os pacientes que foram atendidos no CEGH passaram por consulta com uma equipe multidisciplinar constituída por geneticistas clínicos, biólogos moleculares e aconselhadores genéticos. As dúvidas dos consulentes e de seus responsáveis foram esclarecidas na medida do possível e informações adicionais sobre a pesquisa foram oferecidas sob consulta. Os responsáveis pelos pacientes foram informados sobre os testes genéticos disponíveis, a capacidade diagnóstica dos mesmos e sob a finalidade de pesquisa. A coleta de material (amostra de sangue periférico) para extração de DNA e/ou RNA e/ou estabelecimento de linhagens linfoblastóides dos afetados aconteceu somente após consentimento do responsável do paciente. $\mathrm{O}$ envio do material para outros centros de pesquisa, a divulgação científica e publicação dos dados, incluindo fotos dos pacientes, foi realizada somente mediante autorização dos responsáveis. Todos os responsáveis pelos pacientes que foram estudados no Capítulo 3 receberam um relatório por escrito informando o diagnóstico de síndrome de Snyder-Robinson e foi realizado o aconselhamento genético para a família. 
As amostras de sangue ou DNA genômico encaminhadas para diagnóstico molecular provenientes de outros Centros foram obtidas de acordo com os protocolos de ética dos respectivos locais.

O presente projeto foi aprovado pelo Comitê de Ética do Instituto de Ciência Biomédicas da Universidade de São Paulo (Parecer 458/CEP) e pela Comissão de Ética para Análise de Projetos de Pesquisa - Cappesq da Diretoria Clínica do Hospital das Clínicas da FMUSP. Todos os pacientes e/ou responsáveis assinaram o termo de consentimento permitindo a participação nesta pesquisa.

\section{2) Métodos}

\subsection{1) Extração de DNA de leucócitos de sangue periférico}

Até abril de 2005, DNA genômico dos pacientes e de seus familiares vinha sendo extraído a partir de amostras de sangue periférico segundo o protocolo descrito por Miller et al. (1988). Desde maio de 2005, as amostras de sangue periférico passaram a ser processadas pelo robô de extração de DNA Autopure Ls (Gentra Systems), adquirido pelo CEGH.

Inicialmente as concentrações dos DNAs foram verificadas com o espectrofotômetro (Ultrospec 3000PRO - Amersham Biosciences), utilizando comprimento de onda igual a $260 \mathrm{~nm}$. Mais recentemente as concentrações foram verificadas no aparelho NanoDrop ND-1000 (Peqlab biotechnologie GmbH).

\subsection{2) Extração de RNA de leucócitos de sangue periférico}

O RNA total de amostras de leucócitos de sangue periférico e/ou de células linfoblastóides transformadas com o vírus Epstein-Barr foi extraído de acordo com a técnica de extração com o uso de TRIZOL ${ }^{\mathrm{TM}}$ (Invitrogen).

A qualidade e a concentração do RNA foi verificada no aparelho NanoDrop $N D-1000$, e em gel de agarose $1,2 \%$ após desnaturação a $60^{\circ} \mathrm{C}$ com corante azul de bromofenol contendo formamida.

\subsection{3) Amplificação dos fragmentos de DNA por PCR}

As amostras de DNA genômico e/ou de cDNA utilizadas neste trabalho foram amplificadas pela reação em cadeia da polimerase (PCR - Polymerase Chain Reaction - Saiki et al., 1985), que é uma técnica que permite a amplificação in vitro de 
sequiências específicas de DNA, usando a enzima DNA polimerase, os quatro nucleotídeos, e um par de oligonucleotídeos iniciadores em fitas de DNA complementares. Em cada ciclo, ambas as fitas servem como moldes para a formação de fitas novas, obtendo-se assim um aumento exponencial do produto. Geralmente as reações ocorreram nas seguintes condições: 5 minutos de desnaturação a $94^{\circ} \mathrm{C}, 35$ ciclos de: 40 segundos a $94^{\circ} \mathrm{C}, 40$ segundos a temperatura de anelamento (calculada especificamente para cada par de oligonucleotídeos) e 40 segundos a $72^{\circ} \mathrm{C}$, seguidos de uma etapa de extensão final de 7 minutos a $72^{\circ} \mathrm{C}$. Para cada reação de $25 \mu 1$, geralmente foram utilizados: 100 ng de DNA genômico ou cDNA, tampão $1 \mathrm{X}$ (Pharmacia ou Invitrogen), 1u Taq DNA Polimerase (Pharmacia ou Invitrogen), 200 $\mu \mathrm{M}$ de cada dNTP (Amershan Biosciences) e 0,5 - 1,0 $\mu \mathrm{M}$ de cada oligonucleotídeo. O sucesso da PCR foi verificado por eletroforese horizontal em gel de agarose 1,5\% e tampão TBE 1X a 100 Volts, por aproximadamente uma hora, dependendo do tamanho do fragmento amplificado. Após a eletroforese, o gel foi corado com brometo de etídeo $(0,5 \mu \mathrm{g} / \mathrm{ml})$ e visualizado sob luz ultravioleta a fim de confirmar a presença de uma única banda do tamanho esperado. Os termocicladores utilizados para a amplificação da PCR foram da Perkin Elmer e da PTC-150 MJ Research.

\subsection{4) Triagem de mutação nos genes candidatos}

Foram utilizadas três metodologias para as triagens de mutação neste trabalho:

I) análise em alta resolução da temperatura de melting (Capítulo 3);

II) dHPLC (Capítulo 4);

III) seqüenciamento (Capítulos 3 e 4).

\subsubsection{I) Análise em alta resolução da temperatura de melting (High-resolution} melting analysis)

Esta metodologia foi utilizada para a triagem de mutações no exon 2 do gene SMS nos 316 indivíduos controles caucasóides da população Norte-Americana analisados no Capítulo 3. Ela se baseia na análise da curva de melting dos heteroduplexes formados após a reação de heteroduplex do produto amplificado

englobando o exon 2 de SMS (amplicon). No equipamento LightScanner ${ }^{T M}$ (Idaho Technology), as imagens das curvas de melting do DNA são capturadas por uma 
câmera CCD e ampliadas para revelar detalhes sutis nos perfis das curvas do DNA. Comparações entre as curvas das amostras são utilizadas para interpretar os resultados das sequiências dos DNA. A interpretação correta dos dados é realizada por algoritmos do software da LightScanner ${ }^{T M}$.

A análise em alta resolução da temperatura de melting é comparativa, ou seja, as amostras dos controles investigados foram sempre analisadas em relação a amostras de controles previamente seqüenciados e sem nenhuma alteração genética no amplicon de interesse. A reação utilizada para a análise do exon 2 do gene SMS ocorreu nas seguintes condições: para cada reação de $10 \mu \mathrm{l}$ foram utilizados $100 \mathrm{ng}$ de DNA genômico de um controle sem alteração no amplicon de interesse (já previamente seqüenciado), mais 100 ng de DNA genômico do novo indivíduo analisado, tampão Master Mix $1 X$ (Idaho Technology) e 1,0 $\mu \mathrm{M}$ de cada oligonucleotídeo (a sequiência dos oligonucleotídeos utilizados está descrita na Tabela 3 do Capítulo 3). Uma vez preparada a mistura, esta foi submetida à reação de PCR utilizado o seguinte programa: 2 minutos de desnaturação a $95^{\circ} \mathrm{C}, 40$ ciclos de: 30 segundos a $94^{\circ} \mathrm{C}, 30$ segundos a $65^{\circ} \mathrm{C}$ e 30 segundos a $72^{\circ} \mathrm{C}$, seguidos de mais duas etapas para a formação do heteroduplex: 30 segundos a $94^{\circ} \mathrm{C}$ e 30 segundos a $25^{\circ} \mathrm{C}$. As amostras que apresentaram um padrão diferente do normal foram posteriormente seqüenciadas.

\subsubsection{II) Método de cromatografia líquida desnaturante de alta performance (dHPLC)}

Esta metodologia foi utilizada para a triagem de mutações na maioria dos exons e das junções exon/intron do gene ARHGEF9 nos pacientes analisados no Capítulo 4.

O método de dHPLC (denaturing High Performance Liquid Chromatography - Kuklin et al., 1997) permite a detecção automatizada de alterações na seqüência do DNA por meio de análise de heteroduplex de cromatografia modulado por temperatura. A análise de mutações por meio dessa técnica baseia-se na retenção diferencial de moléculas de heteroduplex de DNA em relação a moléculas de homoduplex em um cartucho de retenção de ácido nucléico sob condições de desnaturação parcial do DNA. Os fragmentos de PCR de heteroduplex contêm uma quantidade maior de regiões não pareadas em comparação aos fragmentos de 
homoduplex, sendo assim retidos por menos tempo do que seus análogos homoduplex no cartucho da fase estacionária (Xiao \& Oefner, 2001).

O método de dHPLC é comparativo, ou seja, as amostras dos pacientes foram sempre analisadas em relação às amostras de controles previamente seqüenciados e sem nenhuma alteração genética nos amplicons de interesse.

A reação utilizada para a análise do gene ARHGEF9 (Capítulo 4) foi a seguinte: $25 \mu 1$ do produto de PCR de um indivíduo do sexo feminino ou 12,5 $\mu 1$ de cada dois produtos de PCR de indivíduos do sexo masculino (misturados) foram submetidos a reação de heteroduplex $\left(95^{\circ} \mathrm{C}\right.$ a 4 minutos, seguidos por um redução lenta e gradativa da temperatura de $95^{\circ} \mathrm{C}$ à $25^{\circ} \mathrm{C}$, por aproximadamente 45 minutos). Como controle, os DNAs de dois indivíduos do sexo masculino sem mutações nos amplicons de ARHGEF9 (já previamente seqüenciados) foram misturados e então submetidos à mesma reação de heteroduplex. Para a análise de dHPLC, as temperaturas de análise dos amplicons do gene ARHGEF9 foram determinadas utilizando o programa Navigator (http://insertion.stanford.edu/melt.html). As sequiências dos oligonucleotídeos utilizados e as temperaturas de análise dos amplicons estão descritas respectivamente nas Tabelas 1 e 2 do Capítulo 4. As amostras que apresentaram um padrão diferente do normal foram posteriormente seqüenciadas.

\subsubsection{III) Seqüenciamento}

Esta metodologia foi utilizada para triagem de mutações nos genes $S M S$ (que codifica a enzima espermina sintase) e ARHGEF9 (que codifica a proteína colibistina) dos pacientes analisados nos Capítulos 3 e 4, e para analisar a seqüência de fragmentos clonados em vetores de expressão utilizados nos Capítulos 3 e 5.

Geralmente o seqüenciamento pode ser dividido em 7 etapas: A) amplificação do fragmento de DNA de interesse pela PCR; B) purificação do produto de PCR; C) quantificação do produto de PCR purificado; D) reação de seqüenciamento; E) precipitação do DNA seqüenciado; F) análise no seqüenciador automático; G) análise de bioinformática dos resultados do seqüenciamento.

\section{A) Amplificação dos fragmentos de DNA pela PCR:}

Para a amplificação dos fragmentos de DNA, ver item 2.2.3. 
B) Purificação do produto de PCR:

Para a purificação dos produtos de PCR, foi utilizado uma das três metodologias descritas abaixo:

- adição de 10u da enzima Exonuclease I (EXO, USB) e de 5u da enzima Shrimp Alkaline Phosphatase (SAP, Amersham Biosciences) ao produto de PCR, seguido de incubação a $37^{\circ} \mathrm{C}$ por 30 minutos e inativação das enzimas a $80^{\circ} \mathrm{C}$ por 15 minutos (Capítulos 4 e 5);

- kit de purificação Quiaquick ${ }^{\circledR}$ PCR Purification (Qiagen) (Capítulos 3 e 5);

- kit de purificação GFX ${ }^{\circledR} P C R$ DNA and Gel Band Purification (GE Healthcare) (Capítulo 3).

C) Quantificação do produto de PCR purificado:

O produto de PCR purificado foi quantificado por uma das duas metodologias descritas abaixo:

- eletroforese em gel de agarose 1,5\% TBE 1X, com a utilização do marcador de peso molecular Low DNA Mass ${ }^{T M}$ Ladder (Invitrogen) ou de um produto de PCR de concentração conhecida (Capítulos 3, 4 e 5);

- pelo aparelho NanoDrop ND-1000 (Capítulo 3).

D) $\underline{\text { Reação de seqüenciamento: }}$

Após a purificação do produto de $\mathrm{PCR}$, foi realizada a reação de seqüenciamento por uma das duas metodologias descritas abaixo:

- seqüenciador MegaBACE ${ }^{T M} 1000$ DA Analysis Systems (Amersham Biosciences, GE Healthcare): a reação de seqüenciamento foi realizada com 20-40 ng de produto de PCR seguindo o protocolo do kit DYEnamic IT Dye Terminator Cycle Sequencing for MegaBACE (Amersham Biosciences, GE Healthcare). A reação foi realizada em 25 ciclos de: desnaturação a $95^{\circ} \mathrm{C}$ por 10 segundos, anelamento a $50^{\circ} \mathrm{C}$ por 10 segundos e extensão a $60^{\circ} \mathrm{C}$ por 1 minuto (Capítulos 3, 4 e 5);

- seqüenciador ABI Prism ${ }^{T M}$ Sequencer 377 (versão 3.0 Applied Biosystems): a reação de seqüenciamento foi realizada com 10-20 ng de produto de PCR (200-500pb: $10 \mathrm{ng}$; 500-1000pb: 20 ng), seguindo o protocolo do kit BigDye Terminator Cycle Sequencing ( $P E$ Biosystems, Foster City, CA). A reação foi realizada com uma 
desnaturação inicial de $96^{\circ} \mathrm{C}$ por 1 minuto, seguida de 30 ciclos de: desnaturação a $96^{\circ} \mathrm{C}$ por 10 segundos, anelamento (temperatura de anelamento de cada oligonucleotídeo) por 5 segundos e extensão a $60^{\circ} \mathrm{C}$ por 4 minutos (Capítulos 3 e 4 ).

E) Precipitação do DNA seqüenciado:

Após a reação de seqüenciamento, o produto seqüenciado foi precipitado por uma das duas metodologias descritas abaixo:

- acetato de amônia 7,5mM e etanol (Capítulos 4 e 5);

- placa MultiScreen (Millipore), utilizando o polímero de Sephadex ${ }^{T M}$ G-50 Fine DNA Grade (GE Healthcare) (Capítulos 3 e 4).

F) Análise nos seqüenciadores automáticos:

Após a precipitação, o DNA seqüenciado foi analisado por um dos dois seqüenciadores descritos abaixo:

- seqüenciador MegaBACE ${ }^{T M} 1000$ DA Analysis Systems (Amersham Biosciences, GE Healthcare). Os aparelhos MegaBACE ${ }^{T M}$ encontram-se em funcionamento no CEGH e no Centro de Genética de Greenwood (Capítulos 3, 4 e 5);

- seqüenciador ABI Prism ${ }^{T M}$ Sequencer 377 (versão 3.0 Applied Biosystems). O aparelho ABI Prism ${ }^{T M}$ Sequencer 377 encontra-se em funcionamento no Departamento de Botânica do Instituto de Biociências - USP (Capítulos 3 e 4).

G) Análise dos resultados do seqüenciamento por bioinformática:

As seqüências foram analisadas pelos softwares descritos abaixo:

- BioEdit (www.mbio.ncsu.edu/BioEdit/bioedit.html) (Capítulos 3, 4 e 5);

- Sequencher (www.sequencher.com) (Capítulos 3 e 4);

- SeqMan ${ }^{T M}$ II (DNASTAR) (Capítulo 3).

\subsection{5) Estudo de ligação genética}

Essa metodologia foi utilizada para mapear e restringir a região candidata a conter o alelo patogênico causador da forma sindrômica de retardo mental com herança recessiva ligada ao cromossomo X na família estudada no Capítulo 3. 
Foram utilizados um total de 24 marcadores polimórficos do tipo microssatélite do cromossomo X. Como parte de seu projeto de doutorado, o aluno Carlos Magno da Costa Maranduba começou essa análise de ligação utilizando 18 marcadores espalhados pelo cromossomo $\mathrm{X}$ e distanciados em média a cada $10 \mathrm{cM}$, do kit ABI PRISM ${ }^{T M}$ Linkage Mapping Set Version 2.0 (Perkin-Elemer, Applied Biosystems) (Maranduba et al., 2005). Essa análise resultou no mapeamento do alelo deletério associado à síndrome na família em Xp22.2-p11.4, uma região de aproximadamente $29 \mathrm{Mb}$ contendo 186 genes. No presente trabalho a região candidata foi restringida com a utilização de mais 6 marcadores microssatélites adicionais mapeados em Xp22.2-p11.4 (os quais foram selecionados com base nos bancos de dados do NCBI - http://www.ncbi.nlm.nih.gov/). Em ambas as análises, o DNA genômico foi amplificado por PCR com oligonucleotídeos fluorescentes, marcados com as fluorescências FAM, HEX, VIC ou NED. Todos os marcadores utilizados constituem de repetições de di nucleotídeos.

Para a amplificação por PCR dos microssatélites em uma reação de $15 \mu 1$ finais, geralmente foram utilizados: 50-100 ng de DNA genômico, tampão $1 \mathrm{X}$ (Invitrogen), 1u Taq DNA Polimerase (Invitrogen), 2,5 mM de cada dNTP (Amershan Biosciences), $1,5 \mathrm{mM}$ de $\mathrm{MgCl}_{2}$ (Invitrogen) e $0,3 \mu \mathrm{M}$ dos oligonucleotídeos fluorescentes. A reação foi realizada com uma desnaturação inicial de 5 minutos a $94^{\circ} \mathrm{C}, 30$ ciclos de: 15 segundos a $94^{\circ} \mathrm{C}, 15$ segundos a $55^{\circ} \mathrm{C}$ e 30 segundos a $72^{\circ} \mathrm{C}$, seguidos de uma etapa de extensão final de 15 minutos a $72^{\circ} \mathrm{C}$. Os produtos de $\mathrm{PCR}$ foram analisados no seqüenciador automático MegaBACE ${ }^{T M} 1000$, de acordo com o protocolo do fabricante, e a análise dos dados foi feita com o programa do MegaBACE $E^{T M}$ (Genetic Profiler ${ }^{\circledR}$ ).

Para cálculo do Lod score de "dois- pontos" foi utilizado o programa MLINK (FASTLINK versão 5.1; http://linkage.rockefeller.edu/soft/). A frequência do alelo da doença foi estabelecida em 0,001 , com penetrância de $100 \%$.

\subsection{6) Análise de Inativação do cromossomo $X$}

Análise do padrão de inativação do cromossomo X (ICX) foi realizada nas mulheres da família brasileira estudada no Capítulo 3.

Essa análise foi realizada pelo aluno Carlos Magno da Costa Maranduba como parte de seu projeto de doutorado (Marambuda et al., 2005). Suscintamente, 
utilizando DNA genômico extraído de leucócitos periféricos das mulheres da família brasileira em estudo, o padrão de ICX foi determinado pela pré-digestão enzimática do DNA com a enzima HpaII, sensível a metilação, seguida por amplificação da repetição polimórfica CAG no gene do receptor de andrógeno (de acordo com metodologia descrita por Allen et al., 1992). O DNA no cromossomo X inativo é resistente a digestão com HpaII e, assim, pode ser amplificado com oligonucleotídeos flanqueando o sítio de restrição dentro da repetição CAG. O DNA do cromossomo X ativo é clivado pela HpaII e assim nenhum produto de PCR é detectado.

\subsection{7) Produção de cDNA a partir de RNA e PCR-> RT-PCR}

Esta metodologia foi utilizada para produzir os cDNAs utilizados para a análise de mutação na região codificadora do gene $S M S$ realizada no Capítulo 3, nas clonagens nos vetores de expressão em células de mamíferos utilizados nos Capítulos 3 e 5, e nas clonagens nos vetores do sistema de duplo-híbrido em leveduras utilizados no Capítulo 5.

Utilizando 2-5 $\mu$ g de RNA total (proveniente de leucócitos sangüíneos, ou de células linfoblastóides imortalizadas, ou de cérebro humano fetal), foi realizada a síntese de cDNA total com o emprego de random hexamers e da enzima transcriptase reversa SuperScript II (Invitrogen), seguindo protocolo-padrão (Ausubel et al., 1997). Em seguida, os diferentes cDNAs totais foram uilizados nas reações de PCR de interesse. As seqüencias dos oligonucleotídeos utilizados nas PCRs para amplificação específica dos fragmentos dos genes de interesse estão descritas nas Tabelas 1 e 6 do Capítulo 3 e nas Tabelas 1 e 3 do Capítulo 5.

\subsection{8) Quantificação de expressão gênica por PCR em tempo real (RealTime- PCR)}

Esta metodologia foi utilizada para quantificar a expressão do gene SMS em leucócitos periféricos dos pacientes e controles estudados no Capítulo 3. Nas reações de PCR em tempo real foi empregado o fluoróforo SYBR Green (Bio Rad).

O SYBR Green é um agente intercalante que quando se liga às moléculas de fita dupla emite uma fluorescência. Como ele é adicionado ao PCR, à medida que novas moléculas de fita dupla são sintetizadas ao passar dos ciclos da reação, a fluorescência aumenta. $\mathrm{O}$ aparelho iCycler $i Q^{T M}$ foi utilizado para detectar a 
fluorescência crescente: quanto mais tardio o ciclo em que a florescência é detectada, menor é o nível de expressão do gene analisado. $\mathrm{O}$ valor quantitativo de expressão, denominado $\mathrm{C}_{\mathrm{T}}$ (Cycle Treshold), é obtido durante a reação: corresponde ao número do ciclo em que a curva de amplificação exponencial se encontra na metade. Esse parâmetro é analisado pelo programa do aparelho.

Foram utilizados três genes normalizadores (controles endógenos) para a análise dos dados de expressão (genes da $\beta$-actina $(A C T B$ ); subunidade $\mathrm{A}$ da RNA polimerase II (POLR2A); e gliceraldeido-3-fosfato desidrogenase (GADPH)). Empregamos uma ferramenta desenvolvida para análise dos dados de PCR em tempo real no Microsoft Excel. Esse aplicativo modificado calcula um fator de normalização da expressão gênica para cada amostra com base na média geométrica dos valores obtidos para os diferentes normalizadores (Vandesompele et al., 2002).

As reações foram feitas em placas de 96 poços (MicroAmp Optical, Applied Biosystems) em triplicata, cada uma com volume de $25 \mu$ l geralmente contendo: 100 ng de RNA, 50X IQ SYBR Green Supermix (Bio Rad), 0,1 $\mu \mathrm{M}$ de cada oligonucleotídeo, 2X Transcriptase Reversa (Bio Rad), completando-se para $25 \mu 1$ com água sem nuclease. Quanto à ciclagem, utilizamos o seguinte programa: 10 minutos a $50^{\circ} \mathrm{C}, 5$ minutos a $95^{\circ} \mathrm{C}, 45$ ciclos de: 10 segundos a $95^{\circ} \mathrm{C}$ e 30 segundos a $60^{\circ} \mathrm{C}, 1$ minuto a $95^{\circ} \mathrm{C}, 1$ minuto a $55^{\circ} \mathrm{C}$ e mais 80 ciclos de: 10 segundos a $55^{\circ} \mathrm{C}$ (com um aumento de $0,5^{\circ} \mathrm{C}$ a cada ciclo). As seqüencias dos oligonucleotídeos utilizados para essa análise estão descritas na Tabela 4 do Capítulo 3. Desenhamos os oligonucleotídeos para esse ensaio no programa Primer Bank (http://pga.mgh.harvard.edu/primerbank/).

\subsection{9) Sistema de duplo-híbrido em levedura}

Esta metodologia foi utilizada no Capítulo 5 para a identificação de proteínas que interagem com a proteína colibistina.

O sistema de duplo-híbrido em levedura (Fields \& Song, 1989) é um ensaio realizado em levedura para detectar interações proteína-proteína (Figura 7). Este sistema pode ser usado para identificar proteínas que se ligam a uma proteína de interesse ou para delinear domínios ou resíduos críticos para uma interação. Para a realização deste estudo, foi utilizado o sistema MATCHMAKER Gal4 Two-Hybrid System 3 da Clontech, onde são utilizadas duas linhagens haplóides da levedura 
Saccharomyces cerevisae (AH109 e Y187) que possuem a capacidade de se fundirem formando assim células diplóides:

Linhagem AH109: contêm quatro genes repórteres, HIS3 (quando ativado, leva à viabilidade da levedura quando plaqueadas em meio sem histidina), ADE2 (quando ativado, leva à viabilidade da levedura quando plaqueadas em meio sem adenina), $\alpha$ galactosidase (quando ativado produz uma proteína que degrada o substrato $\mathrm{X}-\alpha-\mathrm{Gal}$, tornando a levedura azul) e $\beta$-galactosidade (quando ativado produz uma proteína que degrada o substrato $\mathrm{X}-\mathrm{Gal}$, tornando a levedura azul). Esta linhagem foi transformada com plasmídeos que expressam a proteína isca de nosso interesse (colibistina). Em uma segunda etapa, ela também foi transformada simultaneamente com plasmídeos que expressam as proteínas isca e presa (proteínas candidatas a interagir com a colibistina), para ensaios de interação entre essas proteínas.

Linhagem Y187: contém dois genes repórteres, $\alpha$-galactosidase e $\beta$-galactosidade. Esta linhagem já veio transformada com uma biblioteca de cDNA de cérebro humano fetal (Pretransformed Human Fetal Brain MATCHMAKER cDNA Library) da Clontech (Cat. \#HY4028AH). Esta biblioteca foi construída com RNA proveniente de cérebro de 9 fetos caucasóides com 20-25 semanas de gestação.

Quando ocorre cruzamento entre a linhagem AH109, previamente transformada com a proteína isca, e a linhagem Y187, previamente transformada com a biblioteca de cDNA, células diplóides que contêm quatro genes repórteres são formadas. Se as duas proteínas expressas na levedura são capazes de interagir, o complexo resultante ativará a transcrição dos promotores dos genes repórteres, propiciando o crescimento das leveduras em meios seletivos, assim como gerando colônias azuis em meio contendo o substrato apropriado (X- $\alpha-G a l$ ou X-Gal). 

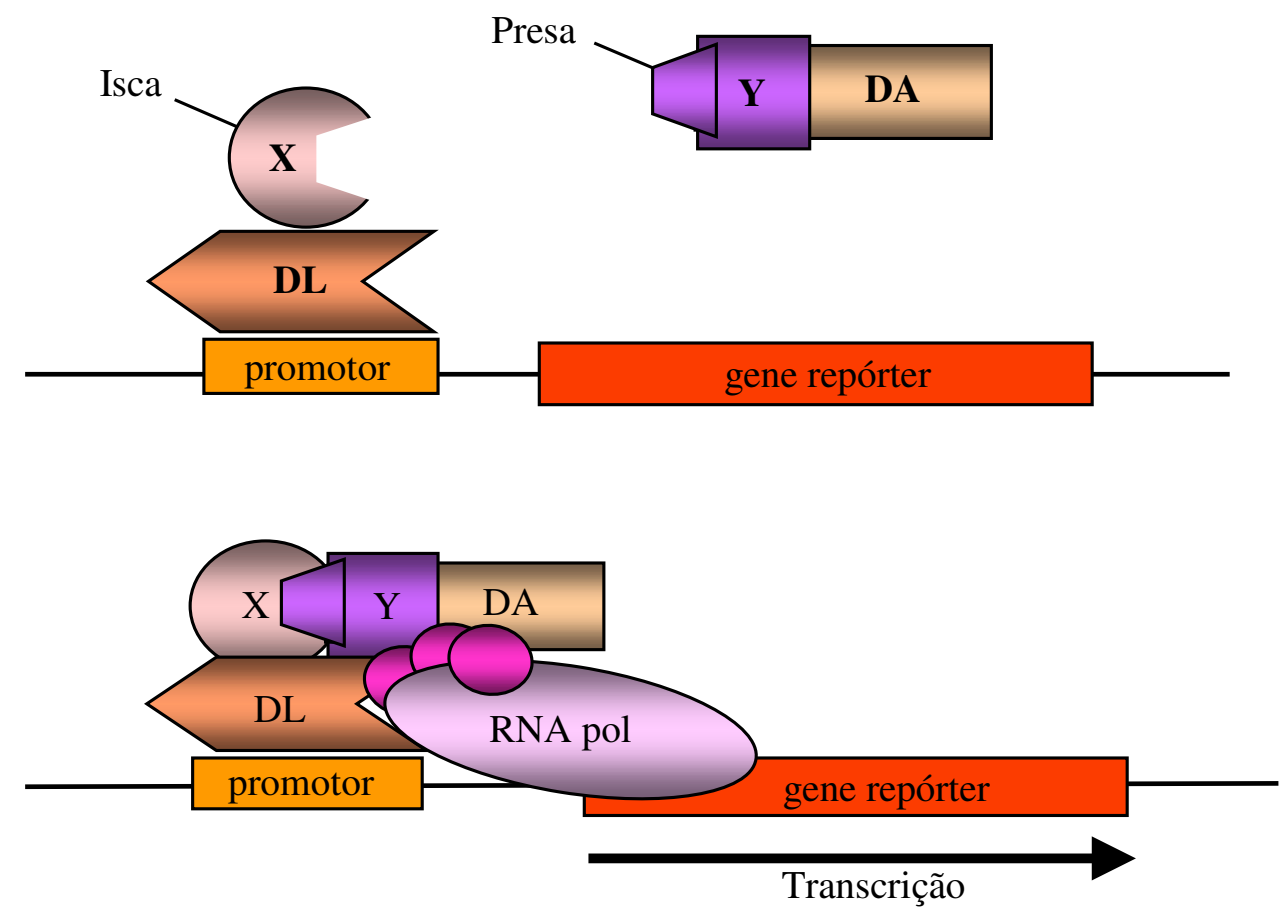

Figura 7. Esquema do sistema de duplo-híbrido em levedura. Esse sistema se baseia na natureza modular da maioria dos fatores de transcrição de eucariotos, os quais são caracterizados por dois domínios funcionais: um domínio que interage com o DNA (domínio DL), mas sozinho não é capaz de ativar transcrição, e outro domínio de ativação de transcrição (DA), que se liga à outros fatores de transcrição e à RNA polimerase, mas que sozinho também não é capaz de ativar transcrição. Quando ocorre interação entre os domínios DL e DA, ocorre transcrição. No sistema de duplohíbrido em levedura o fator de transcrição Gal4 é geralmente utilizado. Nesse sistema, a proteína isca (para a qual se deseja identificar outras proteínas que com ela interajam) é expressa em fusão com o domínio que se liga ao DNA do fator de transcrição Gal4; enquanto que a proteína presa ou biblioteca de cDNA é expressa em fusão com o domínio de ativação de transcrição do fator Gal4. Se as duas proteínas expressas na levedura são capazes de interagir, o complexo resultante ativará a transcrição dos promotores dos genes repórteres, os quais contêm sítios de ligação para o fator de transcrição Gal4.

A metodologia de duplo-híbrido em levedura foi dividida em 5 etapas principais: A) clonagens; B) ensaios prévios do sistema; C) triagem da biblioteca de cDNA de cérebro humano fetal; D) isolamento dos plasmídeos das colônias crescendo nos meios seletivos (denominadas colônias $\mathrm{Ade}^{+}, \mathrm{His}^{+}, \alpha-\mathrm{Gal}^{+}$e $\beta-\mathrm{Gal}^{+}$), amplificação por PCR dos insertos dos plasmídeos da biblioteca de cDNA presentes nessas colônias crescendo nos meios seletivos (plasmídeos contendo a região 
codificadora de proteínas candidatas a interagir com colibistina), seqüenciamento e análise dos mesmos e E) confirmação da interação entre as proteínas candidatas e a proteína colibistina no sistema de duplo-híbrido em levedura.

As etapas iniciais deste estudo (itens A e B) foram realizadas pela Doutora Andréa Laurato Sertié, que é co-orientadora deste trabalho e, na época da implantação dessa metodologia, era pós-doutoranda do Laboratório de Genética do Desenvolvimento Humano (Departamento de Genética e Biologia Evolutiva - IBUSP).

\section{A) Clonagens:}

- Clonagem da região codificadora da proteína colibistina no vetor pGBKT7

O vetor pGBKT7 contêm uma seqüência que codifica o domínio que se liga ao DNA do fator de transcrição Gal4. Além disso, este vetor apresenta: o gene Trp, que permite que a levedura cresça em meio sem triptofano (meio -Trp); o gene Kan, que permite seleção de células bacterianas em meio contendo o antibiótico canamicina; e o epítopo c-myc, o qual permite a identificação da expressão da proteína isca com a utilização do anticorpo comercial anti-cmyc. Empregando RNA proveniente de cérebro humano fetal (Invitrogen), foi realizada a síntese de cDNA total e posteriormente a amplificação específica do cDNA referente a toda região codificadora da proteína colibistina (número de acesso no GenBank: NM_015185) conforme acima descrito (item 2.2.7). Utilizando metodologia padrão de clonagem molecular (Ausubel et al., 1997), o cDNA da colibistina foi clonada no vetor pGBKT7. Essa construção foi denominada de pGBKT7-colibistina. A seqüência correta dessa construção foi verificada por seqüenciamento automático, com a auxílio do aparelho MegaBACE ${ }^{T M}$ (Amersham Biosciences).

\section{- Clonagem da região codificadora da proteína gefirina no vetor pGADT7}

$\mathrm{O}$ vetor pGADT7 contêm uma seqüência que ativa o fator de transcrição Gal4. Além disso, este vetor apresenta: o gene $L e u$, que permite que a levedura cresça em meio sem leucina (meio -Leu); o gene Amp, que permite seleção de células bacterianas em meio contendo o antibiótico ampicilina; e o epítopo HA (hemaglutinina), que permite identificação da expressão da proteína presa com o anticorpo comercial antiHA. Empregando RNA proveniente de cérebro humano fetal (Invitrogen), foi 
realizada a síntese de cDNA total e posteriormente a amplificação específica do cDNA referente a toda região codificadora da proteína gefirina (número de acesso no GenBank: NM_020806) conforme acima descrito (item 2.2.7). Utilizando metodologia padrão de clonagem molecular (Ausubel et al., 1997), o cDNA da gefirina foi clonada no vetor pGADT7. Essa construção foi denominada pGADT7gefirina e foi utilizada como controle positivo de interação com colibistina na sistema de duplo-híbrido. A seqüência correta dessa construção foi verificada por seqüenciamento automático, com a auxílio do aparelho MegaBACE $E^{T M}$.

\section{B) Ensaios prévios do sistema de duplo-híbrido em levedura:}

Os ensaios prévios deste sistema consistiram em:

- Testar se a proteína isca pGBKT7-colibistina ativava sozinha a transcrição dos genes repórteres HIS3, ADE2, $\alpha$-galactosidase e $\beta$-galactosidade quando expressa na levedura AH109;

- Otimizar a concentração de 3-AT (3-amino-1,2,4-triazole) no meio seletivo (como o gene repórter HIS3 apresenta uma expressão basal na levedura AH109, esse composto serve para inibir essa expressão basal);

- Verificar a expressão da proteína isca pGBKT7-colibistina na levedura AH109 por Western blot utilizando um anticorpo comercial anti-cmyc (Clontech);

- Verificar a expressão da proteína presa controle pGADT7-gefirina na levedura AH109 por Western blot utilizando um anticorpo comercial anti-HA (Clontech);

- Testar a toxicidade da proteína isca pGBKT7-colibistina na levedura;

- Testar a eficiência de cruzamento entre a linhagem AH109 contendo a proteína isca pGBKT7-colibistina e a linhagem Y187 transformada com um plasmídeo controle;

- Testar a interação entre as proteínas colibistina e gefirina (controle positivo de interação).

Todos os resultados obtidos confirmaram que o sistema estava funcionando corretamente, de acordo com os padrões sugeridos pelo manual do sistema MATCHMAKER.

C) Triagem da biblioteca de cDNA de cérebro humano fetal:

Foi preparada uma cultura concentrada da linhagem de levedura AH109 transformada com o plasmídeo isca pGBKT7-colibistina $\left(\mathrm{OD}_{600}>0.8\right)$, seguindo o 
protocolo descrito no manual do sistema MATCHMAKER. No dia seguinte, aproximadamente $10 \mathrm{ml}$ dessa cultura foram combinados com uma alíquota de $1 \mathrm{ml}$ da biblioteca de cDNA de cérebro humano fetal pré-transformada na linhagem de levedura Y187 (esta alíquota estava estocada em glicerol a $-70^{\circ} \mathrm{C}$ ). Após 20-24 horas de acoplamento a $30^{\circ} \mathrm{C}$ sob rotação de 30-50 RPM, $100 \mu 1$ da cultura de acoplamento (a qual apresentava volume total de aproximadamente $12 \mathrm{ml}$ ) foram plaqueados em 120 placas de petri de $150 \mathrm{~mm}$ contendo os meios seletivos: i) SD/-Trp/-Leu/His/5mM 3-AT (80 placas) - meio menos seletivo e ii) SD/-Trp/-Leu/-His/-Ade (40 placas) - meio mais seletivo. As placas foram incubadas a $30^{\circ} \mathrm{C}$ por 7 dias.

Foram realizados os procedimentos experimentais necessários para os cálculos do título da biblioteca de cDNA, da eficiência de acoplamento entre as linhagens AH109 e Y187 e da quantidade de clones da biblioteca triados, conforme sugerido pelo manual do sistema MATCHMAKER.

As colônias positivas crescendo nos meios SD/-Trp/-Leu/-His/5mM 3-AT (colônias His ${ }^{+}$) e SD/-Trp/-Leu/-His/-Ade (colônias $\mathrm{Ade}^{+}$e $\mathrm{His}^{+}$) foram selecionadas por ordem de crescimento nas placas e replaqueadas inicialmente no meio seletivo SD/-Trp/-Leu/-His/-Ade/X- $\alpha$-Gal para confirmação do fenótipo $\mathrm{Ade}^{+}$e $\mathrm{His}^{+}$e teste do terceiro gene repórter $\alpha$-galactosidase.

Conforme descrito no manual do sistema MATCHMAKER, essas colônias positivas podem conter mais de um tipo de plasmídeo da biblioteca. Para eliminação de plasmídeos "extras", as colônias positivas foram replaqueadas no meio SD/-Trp/Leu/X- $\alpha$-Gal mais 2-3 vezes (sempre foram escolhidas colônias azuis para serem replaqueadas para a próxima placa; uma mistura de colônias brancas e azuis indicou segregação de plasmídeos). Finalmente, as colônias que cresceram azuis na última placa SD/-Trp/-Leu/X- $\alpha$-Gal foram replaqueadas no meio SD/-Trp/-Leu/-His/-Ade e então submetidas à análise de ativação do quarto gene repórter ( $\beta$-galactosidase). As colônias positivas para esse último teste (ou seja, colônias que teoricamente deveriam expressar além da proteína colibistina uma outra proteína que interege com colibistina) foram denominadas $\underline{\mathrm{Ade}^{+}, \mathrm{His}^{+}, \alpha-\mathrm{Gal}^{+} \mathrm{e} \beta-\mathrm{Gal}^{+}}$. 
D) Isolamento dos plasmídeos das colônias $\mathrm{Ade}^{+}, \mathrm{His}^{+}, \alpha-\mathrm{Gal}^{+}$e $\beta-\mathrm{Gal}^{+}$, amplificação por PCR dos insertos dos plasmídeos da biblioteca de cDNA e seqüenciamento:

Foram extraídos os plasmídeos das colônias $\mathrm{Ade}^{+}, \mathrm{His}^{+}, \alpha-\mathrm{Gal}^{+}$e $\beta-\mathrm{Gal}^{+}$ seguindo o protocolo descrito no manual do sistema MATCHMAKER.

Utilizando oligonucleotídeos iniciadores específicos para seqüências do vetor pGADT7 (AD-F: 5'-CTATTCGATGATGAAGATACCC-3' e AD-R: 5'AGATGGTGCACGATGCACAG-3'), os insertos dos clones da biblioteca de cDNA (insertos-presa) foram amplificados por PCR e seqüenciados, com o auxílio do aparelho MegaBACE ${ }^{T M}$.

Uma vez seqüenciados os insertos, as seqüências foram analisadas com o auxílio do programa BLAST (Basic Local Alignment Search Tool, disponível em www.ncbi.nlm.nih.gov), o qual permite a busca de seqüências conhecidas por meio de servidores públicos. Assim, pudemos verificar se os clones positivos continham insertos que codificavam proteínas conhecidas e/ou com domínios funcionais conhecidos. Outra característica importante dos insertos presentes nesses clones é que eles deveriam apresentar um quadro de leitura que acompanhasse o quadro de leitura do domínio de ativação do fator de transcrição Gal4 presente no vetor pGADT7.

E) Teste da interação entre as proteínas candidatas e a proteína colibistina no sistema de duplo-híbrido em levedura:

Para tal experimento, precisávamos dos plasmídeos pGADT7 contendo insertos codificadores das proteínas candidatas a interagir com colibistina purificados e em quantidades apropriadas para serem transfectados novamente na linhagem de levedura AH109. Assim, bactérias eletrocompetentes (EletroMax DH10B, da Invitrogen) foram transformadas com os plasmídeos-presas isolados das colônias de levedura $\mathrm{Ade}^{+}, \mathrm{His}^{+}, \alpha-\mathrm{Gal}^{+}$e $\beta-\mathrm{Gal}^{+}$e plaqueadas em meio LB (Luria-Bertani) sólido com antibiótico ampicilina $100 \mu \mathrm{g} / \mathrm{ml}$ (para selecionar as colônias que contém o plasmídeo pGADT7). As colônias bacterianas que cresceram no meio seletivo foram então inoculadas em meio LB líquido com ampicilina $100 \mu \mathrm{g} / \mathrm{ml}$ e seus plasmídeos foram extraídos com o kit Qiaprep Spin Miniprep Kit (Qiagen).

Uma vez isolados os plasmídeos-presas em grande quantidade, foi dado início às transformações das células de levedura AH109. Essas células foram transformadas simultaneamente com o plasmídeo pGBKT7-colibistina e com o plasmídeo pGADT7 
contendo toda ou parte da região codificadora das proteínas candidatas a interagir com colibistina, como também com o pGBKT7-colibistina juntamente com o pGADT7- $\phi$ (vetor vazio) (controle negativo), e pGBKT7-colibistina juntamente com o pGADT7gefirina (controle positivo da interação) (o esquema de todas as transformações realizadas está descrito na Tabela 2 do Capítulo 5).

Após a transformação, as leveduras foram plaqueadas nos meios seletivos: $\mathrm{SD} /$-Trp/-Leu (para controle da transformação), SD/-Trp/-Leu/-His/-Ade e SD/-Trp/Leu/-Ade/+5mM 3AT (ambos para testar interação).

\subsubsection{0) Co-imunoprecipitações}

Esta metodologia foi utilizada no Capítulo 5 para confirmar as interações entre a proteína colibistina e as proteínas-presas encontradas com a utilização do sistema de duplo-híbrido em levedura.

Todas as co-imunoprecipitações foram realizadas com o kit Immunoprecipitation Starter Pack (GE Healthcare), seguindo o protocolo sugerido pelo fabricante.

\subsubsection{I) Co-imunoprecipitação das proteínas recombinates superexpressas em células HEK 293T.}

Esta metodologia pode ser dividida em 5 etapas: A) clonagens; B) cultura das células HEK 293T; C) transfecção das células HEK 293T; D) preparação dos lisados protéicos das células HEK 293T e E) co-imunoprecipitação e Western blot.

\section{A) Clonagens:}

Os vetores de expressão em células de mamíferos utilizados para as clonagens foram o pExchange4 (Stratagene) e o pcDNA3 (Invitrogen). O vetor pExchange4 contém na região $\mathrm{N}$-terminal o epítopo c-myc e o vetor pcDNA3 contém na região Nterminal o epítopo flag. Utilizando metodologias padrões de clonagem molecular, o cDNA de toda a região codificadora do gene eIF3-p40 (GenBank: HSU54559) foi inserido no vetor $\mathrm{pExchange} 4$ em fase com a região codificadora do epítopo c-myc (construção pExchange4-eIF3-p40); o cDNA de toda a região codificadora do gene da colibistina (ARHGEF9) (GenBank: NM_015185) foi inserido nos vetores pExchange4 e pcDNA3 em fase com as regiões codificadoras dos epítopos c-myc e flag 
respectivamente (construções pExchange4-colibistina e pcDNA3-colibistina); e o cDNA de toda a região codificadora do gene da gefirina (GPHN) (GenBank: NM_020806) foi inserido no vetor pcDNA3 em fase com a região codificadora do epítopo flag (construção pcDNA3-gefirina). A seqüência correta de todas as construções foi verificada por seqüenciamento automático, com auxílio do aparelho MegaBACE $E^{T M}$, e analisadas com o software BioEdit.

\section{B) Cultura das células HEK 293T:}

A linhagem celular imortalizada HEK 293T (human epithelium from kidney) foi cultivada em meio de cultura DMEM (Dulbecco's Modified Eagle's Médium, Invitrogen) High-Glicose com 10\% de soro fetal bovino (Gibco), 1\% de antibiótico estreptomicina/ampicilina (Sigma-Aldrich), e mantida em estufa a $37^{\circ} \mathrm{C}$ e $5 \% \mathrm{CO}_{2}$.

\section{C) Transfecção das células HEK 293T com os vetores expressando as proteínas de} interesse:

Para os experimentos de transfecção, as células HEK 293T foram cultivadas em placas de cultura de 6 poços até atingirem confluência de 90-95\%, e então foram transfectadas com $4 \mu \mathrm{g}$ do plasmídeo de interesse, utilizando o kit e o protocolo do reagente Lipofectamina 2000 (Invitrogen). Para as transfecções duplas (dois vetores) foram utilizados $2 \mu \mathrm{g}$ de cada plasmídeo e para as transfecções triplas (três vetores) 1,3 $\mu \mathrm{g}$ de cada plasmídeo. O esquema das transfecções está descrito na Tabela 4 do Capítulo 5.

\section{D) Preparação dos lisados protéicos das células HEK 293T:}

Após 48 horas de cultura das células HEK 293T transfectadas, estas foram lavadas 2x com tampão PBS 1X gelado e então foram lisadas e tiveram suas proteínas totais extraídas com a utilização de $500 \mu 1$ do tampão RIPA (50mM de Tris-HCL pH 7.4; 150mM NaCl; 1mM EDTA, $1 \%$ (v/v) Nonidet-40; 0.1\% (w/v) SDS; 0.5\% (w/v) DOC; tablete de inibidores de protease (Roche)) gelado. Os lisados das células foram transferidos para tubos de $1,5 \mathrm{ml}$ e então passados cerca de $10 \mathrm{x}$ por uma agulha $.21 \mathrm{G}$ com auxílio de seringas. Depois, os lisados foram centrifugados a 14.000 RPM por 15 minutos a $4^{\circ} \mathrm{C}$ e os sobrenadantes foram transferidos para novos tubos de $1,5 \mathrm{ml}$ e as 
concentrações de proteínas dos lisados foram estimadas pelo aparelho NanoDrop ${ }^{\circledR}$ ND-1000.

\section{E) Co-imunoprecipitações e Western blot:}

Quinhentos $\mu \mathrm{l}(\sim 15 \mu \mathrm{g})$ de cada um dos lisados de células HEK 293T contendo extratos das proteínas super-expressas foram incubados sob leve agitação com $5 \mu \mathrm{g}$ do anticorpo anti-flag overnight a $4^{\circ} \mathrm{C}$. Após esse período, foram adicionados cerca de $50 \mu \mathrm{l}$ de beads de agarose (Protein G Sepharose ${ }^{\mathrm{TM}}$ ) aos lisados, que foram então incubados por mais 3-4 horas sob leve agitação a $4^{\circ} \mathrm{C}$. Em seguida os lisados foram centrifugados, os sobrenadantes descartados e as beads de agarose lavadas por 3x em tampão RIPA e 1x em tampão Tris 50mM pH 8,0. Por fim, foram adicionados às beads de agarose $30 \mu 1$ de $2 \mathrm{X}$ protein loading buffer $(100 \mathrm{mM}$ Tris $\mathrm{HCl}$ pH 6,8, 20\% de glicerol, 4\% de SDS, 0,2\% de azul de bromofenol, 100 mM DTT), os quais foram aplicados em géis de SDS-poliacrilamida 10\% para os experimentos de Western blot. Após a transferência das proteínas do gel de SDS-poliacrilamida para membranas de nitrocelulose (Hybond ${ }^{T M}$ C Extra - GE Healthcare), estas foram incubadas com o anticorpo primário monoclonal anti-cmyc (produzido em camundongos; Clontech). Foi utilizado o anticorpo secundário anti-camundongo (produzido em cabra) conjugado à enzima peroxidase (Santa Cruz Biotechnology). Proteínas imunorreativas foram então detectadas com o reagente $E C L^{T M}$ Western Blotting Analysis System (Amersham Biosciences), seguindo o protocolo do fabricante. Os experimentos de Western Blot estão mais detalhados no item 2.2.11 abaixo.

\subsubsection{II) Co-imunoprecipitação das proteínas endógenas expressas em cérebros de camundongos adultos congelados}

Esta metodologia pode ser dividida em 2 etapas: A) preparação dos lisados de cérebros de camundondos adultos e B) co-imunoprecipitação e Western blot.

\section{A) Preparação dos lisados de cérebros de camundongos adultos:}

Cérebros de camundongos adultos congelados foram macerados em um cadinho de porcelana (imerso em nitrogênio líquido) até que se tornassem pó e então misturados ao tampão RIPA (razão $500 \mu 1$ tampão/100 mg de tecido macerado). Em 
seguida, cada um dos lisados foi passado por uma agulha $.21 \mathrm{G}$ por cerca de $10 \mathrm{x}$ com auxílio de uma seringa e incubado no gelo por 30 minutos. Durante a incubação, os lisados foram submetidos à agitação máxima no vórtex a cada 5 minutos. Depois os lisados foram centrifugados a 14.000 RPM por 30 minutos. Os sobrenadantes foram transferidos para tubos de $1,5 \mathrm{ml}$ e as concentrações de proteínas dos lisados foram estimadas pelo aparelho NanoDrop ${ }^{\circledR}$ ND-1000.

\section{B) Co-imunoprecipitações e Western blot:}

Quinhentos $\mu \mathrm{l}$ (aproximadamente $10 \mathrm{mg}$ ) de cada um dos lisados de cérebros de camundongos adultos foram incubados sob leve agitação com $5 \mu \mathrm{g}$ do anticorpo anti-eIF3-p116 (gerado em cabra; Santa Cruz Biotechnology) durante a noite a $4^{\circ} \mathrm{C}$ (conforme descrito em detalhes no Capítulo 5). Após a incubação, cerca de $50 \mu 1$ de beads de agarose (Protein $G$ Sepharose ${ }^{\mathrm{TM}}$ ) foram adicionadas aos lisados, que foram incubados por mais 3-4 horas sob leve agitação a $4^{\circ} \mathrm{C}$. Em seguida, os lisados foram centrifugados, os sobrenadantes descartados e as beads de agarose lavadas por 3x em tampão RIPA e 1x em tampão Tris 50mM pH 8,0. Por fim, foram adicionados às beads de agarose $30 \mu \mathrm{l}$ de $2 \mathrm{X}$ protein loading buffer $(100 \mathrm{mM}$ TrisHCl $\mathrm{pH}$ 6,8, $20 \%$ de glicerol, 4\% de SDS, 0,2\% de azul de bromofenol, $100 \mathrm{mM}$ DTT), os quais foram aplicados em géis de SDS-poliacrilamida 10\% para os experimentos de Western blot. Após a transferência das proteínas do gel de SDS-poliacrilamida para membranas de nitrocelulose (Hybond ${ }^{T M}-C$ Extra - GE Healthcare), estas foram expostas aos anticorpos primários anti-colibistina (produzido em camundongo; BD Biosciences), anti-gefirina (produzido em cabra; Santa Cruz Biotechnology), anti-eIF3-p116 (N-20) (produzido em cabra; Santa Cruz Biotechnology) ou anti-eIF3-p40 (produzido em cabra; Santa Cruz Biotechnology). Foi utilizado o anticorpo secundário anticamundongo (produzido em cabra) ou anti-cabra (produzido em burro) ambos conjugados à enzima peroxidase (Santa Cruz Biotechnology). Proteínas imunorreativas foram então detectadas com o reagente $E C L^{T M}$ Western Blotting Analysis System (Amersham Biosciences), seguindo o protocolo do fabricante. Os experimentos de Western Blot estão mais detalhados no item 2.2.11. 


\subsubsection{1) Western blotting}

Os experimentos de Western blot foram utilizados para análises de expressão de proteínas estudadas no Capítulo 5 e também para as análises de coimunoprecipitações realizadas no Capítulo 5.

Geralmente os experimentos de Western blot e marcação das membranas com os anticorpos de interesse podem ser divididos em diferentes etapas: A) preparação do gel de SDS-poliacrilamida, aplicação das amostras e corrida das proteínas do gel; B) transferência das proteínas do gel para membrana de nitrocelulose e bloqueio da membrana; C) exposição da membrana ao anticorpo primário; D) lavagem da membrana exposta ao anticorpo primário e exposição da membrana ao anticorpo secundário; E) lavagem da membrana exposta ao anticorpo secundário e revelação da membrana.

\section{A) Preparação do gel de SDS-poliacrilamida e aplicação das amostras no gel:}

Géis de SDS-poliacrilamida $10 \%$ foram preparados conforme descrito por Maniatis et al. (1982). Suscintamente, os géis de SDS-poliacrilamida (2,5 $\mathrm{ml}$ de 1,5 M Tris- $\mathrm{HCl}(\mathrm{pH} 8,8), 3,3 \mathrm{ml}$ de Acrilamida 30\%, 0,1 ml de SDS 10\%, 0,1 ml de APS 10\%, 0,004 $\mathrm{ml}$ de TEMED puro, para $10 \mathrm{ml}$ ) foram aplicados entre placas de vidro do sistema da BioRad. Após a aplicação dessa primeira parte do gel, adicionou-se uma segunda camada de gel chamada de empilhamento (stack) $(0,5 \mathrm{ml}$ de $1,0 \mathrm{M}$ Tris- $\mathrm{HCl}$ (pH 6,8), 0,67 ml de Acrilamida 30\%, 0,04 $\mathrm{ml}$ de SDS 10\%, 0,04 $\mathrm{ml}$ de APS 10\%, 0,004 $\mathrm{ml}$ de TEMED puro, para $4 \mathrm{ml}$ ). Após a aplicação da camada de empilhamento, foi colocado o pente para moldar os poços nos quais as proteínas são aplicadas.

Antes de aplicar as amostras nos géis, elas foram quantificadas com a utilização do aparelho NanoDrop® ${ }^{\circledR} D-1000$ ou da coloração de Bradford e leitura no espectofotômetro. Quantidades desejadas de proteínas foram misturadas ao $2 \mathrm{X}$ protein loading buffer (100 mM TrisHCl pH 6,8, 20\% de glicerol, 4\% de SDS, 0,2\% de azul de bromofenol, $100 \mathrm{mM}$ DTT) e fervidas durante 5 minutos. Após a fervura, as amostras foram aplicadas nos géis de SDS-poliacrilamida, juntamente com um marcador de peso molecular (Rainbow ${ }^{T M}$ (Amersham), Kaleidoscope ${ }^{T M}$ (BioRad), Spectra $^{T M}$ (Fermentas)).

Os géis foram imersos em tampão Resevoir 1X (200 mM de glicina, 25 mM de Tris, $0,1 \%$ de SDS, para 1 litro) e as proteínas submetidas a eletroforese a uma 
voltagem de 100-120 Volts, durante 2 a 5 horas dependendo do tamanho da proteína analisada.

B) Transferência das proteínas do gel para membranas de nitrocelulose e bloqueio das $\underline{\text { membranas: }}$

Após a eletroforese em gel de SDS-poliacrilamida, as proteínas foram transferidas para membranas de nitrocelulose (Hybond ${ }^{T M}-C$ Extra - GE Healthcare). As transferências foram realizadas em tampão de transferência 1X (194mM de glicina, $24 \mathrm{mM}$ de Tris, 20\% de Álcool metílico 100\%, para 1 litro) durante 1 hora a $300 \mathrm{~mA}$ ou de um dia para o outro a 35 Volts. Ambas realizadas a $4^{\circ} \mathrm{C}$;

Após a transferência das proteínas, as membranas de nitrocelulose foram bloqueadas em 5\% de leite em pó diluído em TBT-tween 1X (150 mM NaCl, 50 mM Tris- $\mathrm{HCl} \mathrm{pH} 7,5,0,1 \%$ de Tween-20, para 1 litro) durante 40 - 60 minutos, a temperatura ambiente, sob agitação horizontal.

C) Exposição da membrana ao anticorpo primário e lavagem da membrana:

Após o bloqueio, as membranas foram expostas aos anticorpos primários (específico para cada proteína analisada) de um dia para o outro, a $4^{\circ} \mathrm{C}$, sob agitação horizontal. Os anticorpos primários foram diluídos (nas razões especificadas pelo fabricante) em 1-5\% leite em pó em TBS-tween 1X ou em 5\% BSA (bovine serum albumin) em TBS-tween $1 X$.

Após a exposição aos anticorpos primários, as membranas foram lavadas em TBS-tween $1 \mathrm{X}$ durante 1 hora, a temperatura ambiente, sob agitação horizontal, trocando o TBS-tween $1 \mathrm{X}$ no mínimo 4x durante essa 1 hora.

D) Exposição da membrana ao anticorpo secundário e lavagem da membrana:

Após as lavagens, as membranas foram expostas aos respectivos anticorpos secundários durante 1 hora, a temperatura ambiente, sob agitação horizontal. Os anticorpos secundários foram diluídos (nas razões indicadas pelo fabricante) em 1-5\% leite em pó em TBS-tween 1X ou em 5\% BSA em TBS-tween 1X.

Após a exposição aos anticorpos secundários, as membranas foram lavadas novamente em TBS-tween $1 \mathrm{X}$ durante 1 hora, a temperatura ambiente, sob agitação horizontal, trocando o TBS-tween 1X no mínimo 4x durante essa 1 hora. 
E) Revelação da membrana:

Após as lavagens, as membranas foram expostas a um dos dois agentes reveladores descritos abaixo:

- ECL ${ }^{T M}$ Western Blotting Analysis System (Amersham Biosciences) durante 1 minuto; - SuperSignal ${ }^{\circledR}$ West Dura Extended Duration Substrate (Thermo Scientific) durante 5 minutos.

Após a exposição ao agente revelador, as membranas foram colocadas dentro de um cassete na câmara escura e foi adicionado o filme de raio-X (T-MAT G/RA Film $18 / 24 \mathrm{~cm}$ - Kodak) por cima delas, que ficou em contado com a membrana durante 1 , 5 e 10 minutos. Os filmes foram revelados em solução reveladora (Revelador $e$ Reforçador GBX - Kodak) e a imagem fixada em solução fixadora (Fixador e Reforçador GBX - Kodak).

\subsubsection{2) Imunoflorescências}

Esta metodologia foi utilizada no Capítulo 3 para a análise da morfologia de células PC-12 (pheochromocytoma cells, uma linhagem de células cancerígenas da medula espinhal de ratos geralmente utilizada como modelo de diferenciação neuronal in vitro) super-expressando as proteínas SMS humanas selvagem e mutada, e pode ser dividida em 4 etapas: A) clonagens; B) cultura das células PC-12; C) transfecção das células PC-12 e D) imunoflorescências.

\section{A) $\underline{\text { Clonagens: }}$}

$\mathrm{O}$ vetor utilizado para as clonagens foi o pBudCE4.1 (Invitrogen). Esse vetor possui dois sítios de clonagens onde cada um contém um promotor próprio e um epítopo na região C-terminal. O primeiro sítio de clonagem contém o promotor $\mathrm{P}_{\mathrm{EF}-1 \alpha}$ e o epítopo V5, e o segundo sítio contém o promotor $\mathrm{P}_{\mathrm{CMV}}$ e o epítopo c-myc. Foram realizadas duas construções diferentes com esse vetor: na primeira foi clonado nos dois sítios o cDNA de toda a região codificadora da proteína SMS selvagem (GenBank: NM_004595) (construção pBudCE4.1 + SMSselv + SMSselv); na segunda foi clonado nos dois sítios o cDNA de toda a região codificadora da proteína SMS com a mutação c.267G>A (construção pBudCE4.1 + SMSmut + SMSmut). A sequiência correta de todas as construções foi verificada por seqüenciamento 
automático, com auxílio do aparelho MegaBACE $E^{T M}$, e analisadas com o software SeqMan ${ }^{T M}$ II (DNASTAR).

\section{B) Cultura das células PC-12:}

A linhagem celular imortalizada PC-12 foi cultivada em meio de cultura DMEM High-Glicose, suplementada com $2 \mathrm{mM}$ de glutamina, $10 \%$ de soro de cavalo (Gibco), 5\% de soro fetal bovino (Gibco), 1\% de antibiótico estreptomicina/penicilina (Sigma-Aldrich), e mantida a $37^{\circ} \mathrm{C}\left(10 \% \mathrm{CO}_{2}\right)$.

\section{C) Transfecção das células PC-12:}

Para os experimentos de transfecção, as células PC-12 foram cultivadas em placas de 12 poços $\left(4 \mathrm{~cm}^{2}\right)$ até atingirem confluência de $50-70 \%$, e então foram transfectadas com 1,5 $\mu \mathrm{g}$ do plasmídeo de interesse, utilizando o kit e o protocolo do reagente Lipofectamina 2000 (o esquema das transfecções está descrito na Tabela 5 do Capítulo 3). Após as transfecções, foram adicionados $100 \mathrm{ng} / \mathrm{ml}$ de fator de crescimento neuronal (NGF) ao meio dessas células para estimular o crescimento.

\section{D) Imunoflorescências:}

Após 24 horas da transfecção, as células PC-12 foram replaqueadas sobre lamínulas (previamente tratadas com Poly-L-Lysine a $37^{\circ} \mathrm{C}$ por 1 hora), e mantidas na estufa a $37^{\circ} \mathrm{C}$ por mais 24 horas com o mesmo meio de cultura. Depois dessas 48 horas de incubação:

- o meio das células foi aspirado, as células foram lavadas 2x com PBS 1X e foi adicionado paraformaldeído $4 \%$ durante 5 minutos;

- as células foram lavadas 2x com PBS 1X e foi adicionado a solução de Triton X-100 $0,1 \%$ durante 5 minutos (para permeabilizar as células);

- as células foram lavadas 2x com PBS 1X e foi adicionada 2x a solução Quench (1,02 g de acetato de sódio $+10 \mathrm{mM}$ de glicina em $50 \mathrm{ml}$ de PBS 1X) (cada vez por 7,5 minutos);

- as células foram lavadas 2x com PBS $1 \mathrm{X}$ e foi adicionada a solução de bloqueio (BSA 0,4\% em PBS 1X) durante 30 minutos;

- os anticorpos primários anti-V5 monoclonal (produzido em camundongo; Invitrogen) e anti-myc policlonal (produzido em coelho; Clontech) foram diluídos em 
solução de bloqueio, adicionados nas células, e incubados durante 1 hora a temperatura ambiente;

- as células foram lavadas 3x de 5 minutos com solução de bloqueio e então os anticorpos secundários Alexa Fluor 488-conjugado a anti-camundongo (Molecular probes) e Alexa Fluor 594-conjugado a anti-coelho (Molecular probes) foram diluídos em solução de bloqueio e incubados sobre as células durante mais 1 hora no escuro a temperatura ambiente;

- as células foram lavadas mais 3x de 5 minutos com solução de bloqueio;

- sob as lamínulas com as células foi adicionado o meio de montagem (mounting media), e então mantidas de um dia para o outro no escuro a $4^{\circ} \mathrm{C}$;

- as células foram então analisadas no microscópio invertido Zeiss Axio Observer.Al associado a uma camera Axio MRc5.

\subsubsection{2) Ferramentas de Bioinformática:}

Ferramentas de bioinformática gerais utilizadas neste trabalho incluem:

- NCBI (http://www.ncbi.nlm.nih.gov/);

- UCSC (http://genome.ucsc.edu);

- ENSEMBL (http://www.ensembl.org/index.html);

- Primer 3 (http://frodo.wi.mit.edu/). 


\section{Capítulo 3}

Este capítulo contém os dados recentemente publicados na revista científica Journal of Medical Genetics (anexo I) e resultados inéditos que foram obtidos após a submissão deste artigo.

Data da publicação: Agosto de 2008

Volume: 45(8)

Páginas: 539-43

Nomes dos autores: Gustavo de Alencastro ${ }^{1}$, Diane E. McCloskey ${ }^{2}$, Susana E. Kliemann ${ }^{3}$, Carlos M. Maranduba ${ }^{1}$, Anthony E. Pegg ${ }^{2}$, Xiaojing Wang ${ }^{2}$, Débora R. Bertola $^{4}$, Charles E. Schwartz ${ }^{5}$, Maria Rita Passos-Bueno ${ }^{1}$, Andréa L. Sertié ${ }^{1}$.

\section{Título em português:}

Nova mutação em SMS leva a uma redução drástica na função da proteína espermina sintase e a uma forma grave de retardo mental sindrômico ligado ao cromossomo X - síndrome de Snyder-Robinson.

\section{Título em inglês:}

New SMS mutation leads to a striking reduction in spermine synthase protein function and a severe form of Snyder-Robinson X-linked recessive mental retardation syndrome.

${ }^{1}$ Centro de Estudos do Genoma Humano, Departamento de Genética e Biologia Evolutiva, Instituto de Biociências, Universidade de São Paulo, SP, Brasil. ${ }^{2}$ Department of Cellular and Molecular Pathology, Penn State University College of Medicine, Hershey, PA, USA. ${ }^{3}$ Associação Cruz Verde, São Paulo, SP, Brazil. ${ }^{4}$ Instituto da Criança do Hospital das Clínicas, Faculdade de Medicina, USP, São Paulo, SP, Brasil. ${ }^{5}$ J.C. Self Research Institute of Human Genetics, Greenwood Genetic Center, Greenwood, South Carolina, USA.

Palavras chave: retardo mental ligado ao cromossomo $\mathrm{X}$, síndrome de SnyderRobinson, espermina sintase (SMS). 


\section{Resumo}

Neste trabalho nós descrevemos a identificação de uma nova mutação em um resíduo altamente conservado localizado na região $\mathrm{N}$-terminal da proteína espermina sintase (SMS), em uma segunda família com retardo mental sindrômico ligado ao cromossomo X - síndrome de Snyder-Robinson (OMIM \#309583). Essa mutação de substituição de aminoácido, p.G56S, reduz drasticamente a atividade da SMS e leva a epilepsia severa e deficiência cognitiva grave. Nossos resultados contribuem para uma melhor delineação e expansão do espectro clínico da síndrome de Snyder-Robinson, corroboram com o importante papel da região N-terminal da proteína SMS em sua função e fornecem maior evidência da importância da SMS no desenvolvimento da atividade intelectual e em outros aspectos do desenvolvimento humano. 


\section{Abstract}

We report the identification of a novel mutation at a highly conserved residue within the N-terminal region of spermine synthase (SMS) in a second family with SnyderRobinson X-linked mental retardation syndrome (OMIM \#309583). This missense

mutation, p.G56S, greatly reduces SMS activity and leads to severe epilepsy and cognitive impairment. Our findings contribute to a better delineation and expansion of the clinical spectrum of Snyder-Robinson syndrome, support the important role of the $\mathrm{N}$-terminus in the function of the SMS protein, and provide further evidence for the importance of SMS activity in the development of intellectual processing and other aspects of human development. 


\section{Introdução}

Em 1969, Snyder e Robinson descreveram uma grande família afetada por uma forma de retardo mental de herança recessiva ligado ao cromossomo X (RM-LX), hipotonia e andar atáxico (Síndrome de Snyder-Robinson - SRS, OMIM \#309583). Em 1996, Arena et al. reavaliaram cinco indivíduos adultos afetados do sexo masculino e, adicionalmente, avaliaram um menino de 2 anos de idade. Eles observaram uma combinação característica de sinais clínicos incluindo retardo mental moderado, assimetria do terço inferior da face, lábio inferior espessado, fala lenta e/ou nasal disártrica, "hábitus" magro com massa muscular reduzida, osteoporose, cifoescoliose, e mãos longas com dedos hiperextensíveis. Outros sintomas menos consistentes incluíam convulsões, pectus excavatum, fenda ou arco palatino elevado e hálux longo. Os sinais clínicos da síndrome parecem se desenvolver gradualmente, pois muitos deles foram observados apenas nos indivíduos adultos. O gene responsável pela síndrome na família foi mapeado por estudo de ligação em Xp22.1.

Mais recentemente, Cason et al. (2003) identificaram uma mutação em sítio de splicing do gene da espermina sintase (gene SMS) nos indivíduos afetados dessa família. O gene SMS codifica uma proteína com 366 resíduos de aminoácidos que catalisa a produção da poliamina espermina a partir da espermidina, poliamina esta com um comprimento de cadeia menor. Poliaminas, ubiquamente presente em eucariotos, são moléculas simples que interagem com uma variedade de macromoléculas e exercem importante função no crescimento e diferenciação celular, assim como nas funções neurológicas (Ikeguchi et al., 2006). A estrutura cristalizada e os domínios funcionais da SMS foram recentemente caracterizados. O domínio Cterminal da proteína, resíduos 173-366, parece conter o sítio ativo, e o domínio Nterminal, resíduos 1-117, parece ser essencial para a atividade e dimerização da proteína (Wu et al., 2008). A mutação no sítio de splicing do gene SMS encontrada na família originalmente descrita com SRS resultou na perda do sítio ativo na região Cterminal, em redução substancial da atividade da SMS ( $\sim 5 \%$ dos controles), e em aumento da razão espermidina/espermina (2,5 vezes a de controles) nas linhagens celulares analisadas (Cason et al., 2003).

Descrevemos aqui a identificação de uma segunda mutação em SMS, uma mutação de troca de aminoácido no domínio N-terminal da proteína, a qual reduz 
muito a atividade da enzima em células linfoblastóides e está associada com uma forma grave da síndrome de Snyder-Robinson.

\section{Pacientes e Métodos}

O consentimento de cada participante ou de seus pais ou responsáveis foi obtido antes da participação neste estudo. Este estudo foi aprovado pelo Comitê de Ética do Instituto de Biociências da Universidade de São Paulo, Brasil (Parecer 458/CEP) e pela Comissão de Ética para Análise de Projetos de Pesquisa - Cappesq da Diretoria Clínica do Hospital das Clínicas da FMUSP.

\section{Pacientes}

Os pacientes da família caucasóide brasileira em estudo foram encaminhados para o Centro de Estudos do Genoma Humano (Instituto de Biociências da Universidade de São Paulo) para aconselhamento genético e estudo molecular. A família é constituída por cinco meninos afetados, dos quais dois já vieram a óbito (Figura 1A).

\section{Cariótipo e avaliação molecular para a síndrome do X-Frágil}

A análise de cariótipo do paciente III-2 foi realizada pelo grupo da Dra. Susana E. Kliemann (Associação Cruz Verde, São Paulo).

A amostra de DNA do paciente III-2 foi submetida ao teste molecular para a síndrome do X-Frágil, conforme descrito por Haddad et al., 1996. O teste molecular para a síndrome do X-Frágil foi realizado pelo grupo da Profa. Dra. Ângela ViannaMorgante do Departamento de Genética e Biologia Evolutiva do Instituto de Biociências da Universidade de São Paulo.

\section{Estudo de ligação}

DNA genômico dos pacientes vivos (III-2, III-11 e IV-3) e de seus familiares foi extraído a partir de amostras de sangue periférico segundo procedimentos baseados no protocolo descrito por Miller et al. (1988). Para o mapeamento do loco associado ao RMS-LX na família foram utilizados inicialmente 18 marcadores do tipo 
microssatélite do kit ABI PRISM ${ }^{T M}$ Linkage Mapping Set Version 2.0 (Perkin-Elemer, Applied Biosystems), distribuídos ao longo cromossomo $\mathrm{X}$ e distanciados em média 10 cM. Posteriormente, para restrição da região candidata, foram utilizados mais 6 marcadores microssatélites mapeados em Xp22.2-p11.4 (DXS8019, DXS999, DXS7593, DXS1226, DXS1214, DXS1049). As genotipagens foram feitas com o auxílio do equipamento e do software do MegaBACE ${ }^{T M}$ (Genetic Profiler). Para cálculo do Lod score de "dois-pontos" foi utilizado o programa MLINK (FASTLINK versão 5.1 ; http://linkage.rockefeller.edu/soft/). A frequência do alelo da doença foi estabelecida em 0,001, com penetrância de $100 \%$.

\section{Análise do gene SMS}

- Análise do cDNA do gene SMS por RT-PCR

RNA total de leucócitos periféricos e/ou de células linfoblastóides transformadas com o vírus Epstein-Barr de quatro indivíduos da família brasileira em estudo (três afetados - III-2, III-11, IV-3, e uma mulher heterozigota certa - II-1) foi isolado utilizando o reagente TRIZOL $^{\mathrm{TM}}$ (Invitrogen).

Para triagem de mutação no cDNA do gene SMS foram utilizados dois pares de oligonucleotídeos específicos para a amplificação pela RT-PCR de toda região codificadora do gene (a qual contém 1101 pares de bases) (Tabela 1), que foi então analisada por sequienciamento. A síntese do cDNA e a PCR foram realizadas utilizando o kit SuperScript ${ }^{T M}$ One-Step RT-PCR with Platinum ${ }^{\circledR}$ Taq (Invitrogen), seguindo o protocolo do fabricante.

A análise da expressão do gene SMS em leucócitos periféricos da mulher portadora II-1 foi feita com a utilização do par de oligonucleotídeos "cDNA 1", descrito na Tabela 1.

- Triagem da mutação c.267G>A encontrada no exon 2 do gene $S M S$ nos demais $\underline{\text { membros da família e em indivíduos controles da população }}$

Para a triagem da mutação c. $267 \mathrm{G}>$ A utilizando DNA genômico, dois pares de oligonucleotídeos intrônicos flanqueando o exon 2 do gene SMS foram desenhados. O primeiro par (Tabela 2) foi construído para análise (por seqüenciamento) do exon 2 de SMS dos indivíduos da família brasileira em estudo e de mais 270 indivíduos 
controles caucasóides da população brasileira (132 homens e 138 mulheres). O segundo par (Tabela 3) foi construído para análise (pela metodologia de alta resolução da temperatura de melting) do exon 2 de SMS de 316 indivíduos controles caucasóides do sexo masculino da população Norte-America.

\section{- Seqüenciamento}

Para seqüenciamento dos produtos das reações de RT-PCR ou de PCR, os mesmos foram purificados com a utilização das enzimas Exonuclease (USB) e Fosfatase Alcalina (Amersham Biosciences) e então sequienciados com o auxílio de dois aparelhos distintos: seqüenciador MegaBACE $E^{T M} 1000$ DNA Analysis Systems (Amersham Biosciences), usando o kit Premix (Amersahm Biosciences) e o seqüenciador ABI Prism ${ }^{T M}$ Sequencer 377 (versão 3.0 Applied Biosystems), usando o kit BigDye Terminator Cycle Sequencing (PE Biosystems, Foster City, CA). Nas reações de seqüenciamento foram utilizados os mesmos pares de oligonucleotídeos utilizados nas reações de RT-PCR ou de PCR (Tabelas 1 a 3). As seqüências foram $\begin{array}{lllll}\text { analisadas } & \text { os } & \text { softwares }\end{array}$ (www.mbio.ncsu.edu/BioEdit/bioedit.html) e Sequencher (www.sequencher.com).

- Análise em alta resolução da temperatura de melting (High-resolution melting $\underline{\text { analysis) }}$

Esta análise foi realizada no aparelho Lightscanner ${ }^{T M}$ (Idaho Technology) de acordo com o protocolo do fabricante e os resultados analisados com auxílio do software do Lightscanner ${ }^{T M}$.

\section{Análise de Inativação do cromossomo X}

A análise do padrão de inativação do cromossomo X (ICX) foi realizada com DNA genômico extraído de leucócitos periféricos de cinco mulheres da família brasileira em estudo (II-1, II-2, II-5, II-6 e III-10). O padrão de ICX foi determinado pela pré-digestão enzimática do DNA com a enzima HpaII, sensível a metilação, seguida por amplificação da repetição polimórfica CAG no gene do receptor de andrógeno (Allen et al., 1992). O DNA no cromossomo X inativo é resistente a digestão com HpaII e, assim, pode ser amplificado com oligonucleotídeos 
flanqueando o sítio de restrição dentro da repetição CAG. O DNA do cromossomo X ativo é clivado pela HpaII e assim nenhum produto de PCR é detectado.

\section{Análises do conteúdo das poliaminas}

As poliaminas putrescina, espermidina e espermina foram separadas e quantificadas por HPLC conforme descrito por Seiler \& Knodgen (1985) e Pegg et al. (1989).

\section{Análise da atividade da enzima espermina sintase}

A atividade da SMS foi determinada pela quantificação da produção de $\left[{ }^{35} \mathrm{~S}\right]$ metilthioadenosina proveniente do $\left[{ }^{35} \mathrm{~S}\right]$ AdoMet descarboxilado, em presença de 0.5mM de espermidina (conforme descrito por Wiest \& Pegg, 1998).

\section{Análise da conservação do aminoácido trocado na proteína espermina sintase}

Para análise da conservação do aminoácido trocado na proteína SMS (p.G56) identificado nos membros da família brasileira em estudo, foi utilizado o programa Work Bench (http://workbench.sdsc.edu/), o qual alinha a sequiência da proteína SMS humana com as seqüências da proteína SMS de outros vertebrados. A seqüência da SMS humana foi alinhada com as seqüências de galinha, vaca, lagarto, cachorro, rato, camundongo, marsupial, sapo e peixe.

\section{Quantificação da expressão do gene SMS por PCR em Tempo Real}

Com o objetivo de avaliar se a mutação c. $267 \mathrm{G}>\mathrm{A}$ levava a uma diminuição dos níveis de RNAm do gene $S M S$, o RNAm de $S M S$ dos três indivíduos afetados da família brasileira (III-2, III-11, IV-3) e de cinco indivíduos controles da população de mesma raça e mesmo sexo foi quantificado pela metodologia de PCR em Tempo Real com a utilização do fluoróforo SYBR Green (Bio Rad) e com o auxílio do equipamento iCycler $i Q^{T M}$ (BioRad). As sequiências dos oligonucleotídeos utilizados para a análise do gene $S M S$ e dos genes utilizados como controles endógenos do experimento (genes da $\beta$-actina $(A C T B)$, subunidade A da RNA polimerase II $(P O L R 2 A)$ e gliceraldeido-3-fosfato desidrogenase $(G A D P H)$ ) estão descritas na Tabela 4. 


\section{Análise da morfologia de célula neuronal PC-12}

Para a análise da morfologia de células PC-12 (pheochromocytoma cells, uma linhagem de células cancerígenas da medula espinhal de ratos geralmente utilizada como modelo de diferenciação neuronal in vitro) expressando a proteína SMS selvagem e a proteína SMS mutada foram realizados experimentos de imunoflorescência.

Para esses experimentos, inicialmente $5 \mu \mathrm{g}$ de RNA total extraído de células linfoblastóides de um indivíduo controle normal e de um indivíduo afetado (III-2) foram convertidos para cDNA e amplificados com a utilização do kit SuperScript ${ }^{T M}$ One-Step RT-PCR with Platinum ${ }^{\circledR}$ Taq (Invitrogen), seguindo o protocolo do fabricante. A seqüência dos oligonucleotídeos iniciadores específicos utilizados para amplificar o cDNA das proteínas SMS selvagem (GenBank: NM_004595) e da proteína SMS com a mutação p.G56S estão descritos na Tabela 5. Após a amplificação, os cDNAs foram clonados no vetor pBudCE4.1 (Invitrogen), o qual apresenta dois sítios de clonagem em fase com os epítopos V5 e c-myc respectivamente: construção pBudCE4.1 + SMSselv + SMSselv (cDNA da proteína SMS selvagem) e construção pBudCE4.1 + SMSmut + SMSmut (cDNA da proteína SMS mutada). A seqüência correta de todas as construções foi verificada por seqüenciamento automático, com auxílio do aparelho $M e g a B A C E^{T M}$, e analisadas com o software SeqMan ${ }^{T M}$ II (DNASTAR).

Após as clonagens, as células PC-12 foram cultivadas no meio DMEM HighGlicose (Invitrogen) e transfectadas com as construções acima descritas, utilizando o reagente Lipofectamina 2000 (Invitrogen) e seguindo o protocolo do fabricante (o esquema das transfecções encontra-se na Tabela 6).

Para visualização das proteínas SMS humanas expressas nas células PC-12, utilizamos os anticorpos primários anti-V5 monoclonal (produzido em camundongo; Invitrogen) e anti-myc policlonal (produzido em coelho; Clontech), os quais foram detectados com os anticorpos Alexa Fluor 488-conjugado a anti-camundongo (Molecular probes) e Alexa Fluor 594-conjugado a anti-coelho (Molecular probes), respectivamente. As células foram analisadas no microscópio invertido Zeiss Axio Observer.A1 associado a uma câmera Axio MRc5. 


\section{Estudo Clínico}

A descrição clínica, resumida na Tabela 7 , foi obtida de três indivíduos afetados: III-2, III-11 e IV-3. Existe grande variabilidade clínica entre os pacientes e nenhuma anormalidade fenotípica foi observada nas mulheres portadoras obrigatórias do alelo mutado.

Paciente III-2. O paciente III-2, o probando, nasceu a termo, depois de uma gestação sem complicações, com um peso de $3050 \mathrm{~g}$ (50 centil). Ele apresentou um atraso global do desenvolvimento: suportou a cabeça aos 2 anos de idade, sentou sem suporte aos 3 anos e caminhou com assistência aos 5 anos. Convulsões mioclônicas iniciaram-se aos 2 anos. Atualmente, com 12 anos de idade (Figura 1B), ele apresenta retardo mental profundo, ausência da fala, convulsões tônico-clônicas generalizadas (tratadas com ácido valpróico, carbamazepina e nitrazepan) e é incapaz de levantar-se sozinho ou andar. No exame físico ele apresentou: peso de $20,10 \mathrm{~kg}$ (abaixo do $3^{\circ}$ centil), altura de $128 \mathrm{~cm}$ (abaixo do $3^{\circ}$ centil) e circunferência de cabeça de $52 \mathrm{~cm}$ $\left(50^{\circ}\right.$ centil). Um leve dismorfismo facial foi observado com hipertelorismo médio e exoftalmia, filtro curto, lábio inferior espessado, arco palatino levemente elevado, prognatismo mandibular e orelhas com antihélices proeminentes e lóbulos hipoplásicos. Ele apresenta audição normal e miopia elevada (-8/-9 dpt). Outras características importantes incluem pectus carinatum, criptorquidismo, cifoescoliose grave, camptodactilia sem aracnodactilia. Não foram observadas anormalidades nos pés. Ele possui hipotonia muscular grave, musculatura reduzida e diminuição da gordura subcutânea. Exames complementares revelaram eletrocardiograma e ecocardiograma normais e, por ultra-som abdominal, rim direito ectópico. Exames esqueléticos mostraram osteopenia generalizada, platispondilia e cifoescoliose dorso lombar. Imagem de ressonância magnética revelou ausência óbvia de anormalidades estruturais, mas presença de pequenas calcificações palidais bilaterais. O cariótipo e a avaliação molecular para a síndrome do X-Frágil não evidenciaram anormalidades visíveis por essas metodologias.

Paciente III-11. O paciente III-11 nasceu a termo, depois de uma gestação sem complicações, com um peso de $2800 \mathrm{~g}\left(10^{\circ}\right.$ centil $)$ e comprimento de $51 \mathrm{~cm}\left(50-75^{\circ}\right.$ centil). Ele também apresentou atraso no desenvolvimento motor: sentou com 1 ano de idade, engatinhou com 2 anos e nunca caminhou sem assistência. Seu atraso 
cognitivo foi um pouco menos severamente afetado quando comparado com o observado em seus dois parentes afetados (III-2 e IV-3). Ele começou a falar simples palavras aos 5 anos. Aos 15 anos ele desenvolveu convulsões generalizadas. Atualmente, com 23 anos de idade (Figura 1B), ele apresenta retardo mental grave; ele não consegue ler ou escrever, mas entende simples comandos e repete nomes. Sua fala é lenta e nasal. Suas convulsões são tratadas com carbamazepina, fenobarbital e clobazam. No exame físico ele apresentou peso de $55 \mathrm{~kg}\left(25-50^{\circ}\right.$ centil $)$ e circunferência de cabeça de $56 \mathrm{~cm}\left(50^{\circ}\right.$ centil). Sua altura não pode ser avaliada adequadamente devido a uma cifoescoliose bastante grave. Sua face é longa com aparência grosseira, boca grande e permanentemente aberta, lábio inferior espessado, filtro curto, prognatismo mandibular e orelhas com dobradura deficiente da antihélice. Ele apresenta audição normal e miopia (-4.5). Suas outras características clínicas incluem: pectus carinatum, graves contraturas nas juntas dos membros, dedos longos e hiperextensíveis e hálux valgo sob outros dedos do pé. Ele apresenta pronunciada hipotonia muscular, diminuição da massa muscular e diminuição da gordura subcutânea. Sua coordenação motora e força parecem normais. Ele não foi avaliado para osteoporose, mas nunca teve uma fratura óssea. Os exames de tomografia computadorizada do crânio e eletrocardiograma foram normais.

Paciente IV-3. O paciente IV-3 nasceu a termo, depois de uma gestação sem complicações, com um peso de $3100 \mathrm{~g}$ (50-75 centil) e comprimento de $49 \mathrm{~cm}$ (10$25^{\circ}$ centil). Ele também apresentou atraso do desenvolvimento psicomotor. Ele sentou aos 2 anos, engatinhou aos 3 anos e começou a dar alguns passos, sem assistência, aos 5 anos. Aos 2 anos de idade ele desenvolveu convulsões generalizadas. Atualmente, com 6 anos de idade (Figura 1B), ele apresenta retardo mental grave, ausência de fala, agitação intensa e convulsões graves tratadas com fenobarbital e neuleptil. Ele é capaz de andar por curtas distâncias com um andar de base alargada e instável. No exame físico, ele apresentou peso de 23,0 $\mathrm{kg}\left(25-50^{\circ}\right.$ centil), altura de $106 \mathrm{~cm}$ (abaixo do $3^{\circ}$ centil) e circunferência da cabeça de $53,5 \mathrm{~cm}$ (50-98 centil). Características faciais incluem testa ampla, lábio inferior levemente espessado, leve prognatismo mandibular e um pronunciado desvio de septo. Ele possui audição e acuidade visual normais. Outras características importantes incluem: pectus carinatum, cifoescoliose moderada, hipotonia muscular, diminuição da massa muscular, mas força muscular normal. As mãos são normais, mas com dedos hiperextensíveis. Nenhuma anormalidade foi 
observada nos pés. Ele não foi avaliado para osteoporose, mas nunca sofreu alguma fratura óssea. Os exames de tomografia computadorizada do crânio e eletrocardiograma foram normais.

\section{Resultados e Discussão}

Observamos que os pacientes da família brasileira em estudo compartilham características fenotípicas com aqueles descritos na família originalmente descrita com síndrome de Snyder-Robinson. Entretanto, alguns outros sinais clínicos foram distintos (Tabela 7) e não nos permitiram confirmar o diagnóstico baseado somente nas análises clínicas.

\section{Estudo de ligação genética}

Realizamos um estudo de ligação na família brasileira utilizando marcadores de DNA do tipo microssatélites espalhados por todo o cromossomo $\mathrm{X}$ e encontramos ligação em Xp22-Xp21.1, entre os marcadores DXS999 e DXS1049, com um lod score máximo de 2.9 para o marcador DXS1226 (Figura 1A). Essa região contém o gene $S M S$, fazendo dele o melhor gene candidato.

\section{Análise do gene SMS}

Triamos mutação em toda a região codificadora do cDNA do gene SMS nos três pacientes da família em estudo (III-2, III-11 e IV-3) por seqüenciamento e identificamos uma troca de nucleotídeo, c.267G>A (seqüência referencia NM_004595) no exon 2, a qual resulta em substituição do aminoácido Glicina na posição 56 da proteína pelo aminoácido Serina, p.G56S.

Pelo seqüenciamento do exon 2 de $S M S$ utilizando DNA genômico dos demais membros da família confirmamos que a mutação segrega com o fenótipo da doença na família (Figura 1C), consistente com os dados de haplótipos provenientes do estudo de ligação. 


\section{Triagem da mutação c.267G >A em indivíduos controles}

A mutação c.267G>A no exon 2 do gene $S M S$ não foi detectada entre 724 cromossomos X controles (448 homens e 138 mulheres), indicando que essa mutação provavelmente não é uma variante freqüente na população.

\section{Análise de inativação do cromossomo $X$}

Examinamos o padrão de inativação do cromossomo X (ICX) em cinco mulheres da família brasileira em estudo pela avaliação da metilação da repetição CAG do loco do receptor de andrógenos em Xq11-12. Observamos que a ICX foi significantemente desviada em todas as portadoras do alelo mutado testadas (Figura 1D). Ainda, somente a expressão do alelo do tipo selvagem do gene $S M S$ foi detectada em leucócitos periféricos da mulher portadora II-1, indicando que o alelo mutado é de fato preferencialmente silenciado (dado não apresentado).

Desvio da ICX também foi observado nas mulheres portadoras da família originalmente descrita com SRS (Plenge et al., 1997). Estes resultados sugerem que leucócitos expressando o SMS mutado são negativamente selecionados in vivo, o que está de acordo com muitos outros loci de RM-LX, nos quais padrão desviado de ICX tem sido observado em portadoras assintomáticas (Plenge et al., 2002).

\section{Análise da atividade de SMS e dos níveis das poliaminas}

Para investigar o efeito da mutação p.G56S na função da proteína SMS, medimos inicialmente a atividade da SMS em linhagens de células linfoblastóides imortalizadas (LCL) dos três pacientes (III-2, III-11 e IV-3) e não detectamos nenhuma atividade enzimática (Figura 2A). Adicionalmente, uma redução dos níveis de espermina e uma aumento na relação espermidina/espermina (cerca de 6 vezes a de controles) foram observados em LCL do paciente III-2 (Figura 2B).

É difícil predizer a atividade residual da SMS mutada nos tecidos neuronais e existe uma possibilidade de que a atividade da enzima mutada varie de acordo com o tipo de tecido. Contudo, Cason et al. (2003) observaram uma redução similar na atividade da enzima e níveis alterados das poliaminas em células linfoblastóides e fibroblastos de pacientes da família originalmente descrita com SRS. Portanto, é possível que a redução na atividade da SMS e as alterações nos conteúdos celulares das poliaminas sejam um fenômeno geral por todo o corpo dos indivíduos afetados. 


\section{Análise da conservação do aminoácido trocado}

O resíduo de Glicina na posição 56 da região N-terminal da proteína SMS é altamente conservado na evolução (Figura 2C). Uma vez que a SMS funciona como um homodímero e o domínio N-terminal parece ser essencial para a formação do dímero (Wu et al., 2008), é possível que a substituição p.G56S, a qual introduz um aminoácido com uma cadeia lateral maior, prejudique a dimerização e funcionamento da SMS. Como um pouco de espermina estava presente nas LCL do indivíduo afetado III-2, é provável que alguma atividade residual da SMS esteja presente in vivo, embora a atividade esteja abaixo do limite de detecção nos ensaios com os extratos celulares.

\section{Quantificação da expressão do gene SMS em indivíduos afetados}

Analisamos a expressão do gene $S M S$ nas células linfoblastóides dos três pacientes (III-2, III-11 e IV-3) por PCR em Tempo Real e não encontramos diferenças da expressão em relação a indivíduos controles (dados não apresentados). Assim, parece que o alelo mutado c.267G>A está sendo transcrito normalmente e que, portanto, a mutação p.G56S deve estar ocasionando alteração da função e/ou estabilidade da proteína.

\section{Análise da morfologia de células PC-12 expressando as proteínas SMS selvagem ou SMS mutada}

Células PC-12 (pheochromocytoma cells) expressando a proteína SMS humana com a mutação p.G56S apresentaram uma redução nos prolongamentos neuronais quando comparadas com as células expressando a proteína SMS humana selvagem (Figura 3). Esses resultados sugerem que SMS desempenha papel importante nos mecanismos de expansão dos prolongamentos neuronais e que a proteína SMS com a mutação não funciona de maneira adequada para formação desses processos. Essa alteração no fenótipo das células PC-12 expressando a proteína SMS mutada pode refletir o fenótipo das células neuronais dos pacientes, podendo ser uma das causas dos problemas cognitivos neles encontrados.

Retardo mental, anormalidades na fala e na marcha, convulsões, lábio inferior espessado, palato com arco elevado, corpo magro com hipoplasia muscular, cifoescoliose, osteoporose, mãos/dedos longos e dedos hiperextensíveis, foram observados nos indivíduos afetados de ambas as famílias com SRS, embora com 
gravidade variável (Tabela 7; Figura 1B). Portanto, os dados indicam que esses sinais clínicos provavelmente são característicos da síndrome. Hálux longo e estatura alta não puderam ser avaliados adequadamente no paciente adulto (III-11) da presente família brasileira em estudo, mas não foram observados nas crianças (III-2 e IV-3), sugerindo que essas manifestações clínicas podem ser específicas da primeira família descrita ou, como comentado anteriormente, podem se tornar evidentes somente após a puberdade (Arena et al., 1996; Cason et al., 2003). Adicionalmente, nem pectus excavatum e assimetria facial foram observados nos pacientes da família aqui descrita.

Por outro lado, existem algumas características clínicas que foram observadas principalmente nos pacientes com a mutação p.G56S, incluindo filtro curto, prognatismo mandibular, anormalidades na orelha, miopia elevada e pectus carinatum. Ainda, o desenvolvimento psicomotor e cognitivo nesses pacientes foi mais severamente prejudicado: os dois meninos mais novos são desprovidos de qualquer contato social e são incapazes de falar, e o paciente mais velho é capaz de seguir simples comandos e falar somente algumas palavras. Ainda, as convulsões nesses pacientes são de difícil controle, apesar do tratamento com altas doses de diferentes drogas antiepiléticas. Esses achados apontam em direção a uma maior patogenicidade da mutação p.G56S quando comparado com a mutação que altera o sítio de splicing encontrada na família originalmente descrita com SRS, mutação esta que parece estar associada com níveis relativamente maiores de atividade enzimática em comparação com os da presente família brasileira.

Juntos esses resultados indicam que a substituição p.G56S leva a uma redução ainda maior nos níveis de espermina e alteração dos níveis relativos das poliaminas nas células, o que poderia explicar um prejuízo mais grave do desenvolvimento e funcionamento neuronal. Adicionalmente, a discrepância clínica entre os indivíduos afetados de ambas as famílias também pode ser atribuída a diferenças nos hábitos alimentares, visto que a dieta alimentar contribuí com quantidades significativas de poliaminas no organismo (Zoumas-Morse et al., 2007). Isso também pode explicar em parte o fato de que os fenótipos observados nos indivíduos afetados de ambas as famílias são diferentes daqueles descritos para o camundongo nocaute para Sms (camundongo Gy) (Meyer et al., 1998; Lorenz et al., 1998).

Em conclusão, este estudo descreve a segunda mutação no gene SMS associada com a síndrome de Snyder-Robinson, adiciona características clínicas à síndrome, 
evidencia um domínio funcional crítico localizado na região $\mathrm{N}$-terminal da proteína SMS, e ainda indica uma importante função exercida pela SMS em muitos órgãos, notavelmente no sistema nervoso central e no esqueleto.

\section{Agradecimentos}

Primeiramente gostaríamos de agradecer os membros da família pela cooperação e vontade de participar nesta pesquisa. Agradecemos também a Constância G. Urbani pela assistência secretarial e Marta Canovas pelas contribuições técnicas. Agradecemos ao grupo da Profa. Dra. Ângela Vianna-Morgante pela colaboração neste estudo e realização do teste molecular da síndrome do X-Frágil nos pacientes. Este trabalho foi financiado por bolsas da Fundação de Amparo à Pesquisa do Estado de São Paulo (FAPESP), do Conselho Nacional de Desenvolvimento Científico e Tecnológico (CNPq), do NICHD (HD26202) para CES, do NIH (GM-

26290) para AEP e, em parte, pela bolsa do South Carolina Department of Disabilities and Special Needs (SCDDSN). Dedicado em memória de Ethan Francis Schwartz 1996-1998. 


\section{Referências bibliográficas}

Allen RC, Zoghbi HY, Moseley AB, Rosenblatt HM, Belmont JW. (1992) Methylation of HpaII and HhaI sites near the polymorphic CAG repeat in the human androgen-receptor gene correlates with $\mathrm{X}$ chromosome inactivation. Am J Hum Genet 51(6):1229-39

Arena JF, Schwartz C, Ouzts L, Stevenson R, Miller M, Garza J, Nance M, Lubs H. (1996) X-linked mental retardation with thin habitus, osteoporosis, and kyphoscoliosis: linkage to Xp21.3-p22.12. Am J Med Genet 64:50-58

Cason AL, Ikeguchi Y, Skinner C, Wood TC, Holden KR, Lubs HA, Martinez F, Simensen RJ, Stevenson RE, Pegg AE and Schwartz CE. (2003) X-linked spermine synthase gene (SMS) defect: the first polyamine deficiency syndrome. Eur J Hum Genet 1(12):937-44

Haddad LA, Mingroni-Netto RC, Vianna-Morgante AM, Pena SD. (1996) A PCRbased test suitable for screening for fragile $\mathrm{X}$ syndrome among mentally retarded males. Hum Genet 97(6):808-12

Ikeguchi Y, Bewley MC, Pegg AE. (2006) Aminopropyltransferases: function, structure and genetics. J Biochem (Tokyo) 139(1):1-9

Lorenz B, Francis F, Gempel K, Böddrich A, Josten M, Schmahl W, Schmidt J, Lehrach H, Meitinger T, Strom TM. (1998) Spermine deficiency in Gy mice caused by deletion of the spermine synthase gene. Hum Mol Genet 7(3):541-7

Meyer RA Jr, Henley CM, Meyer MH, Morgan PL, McDonald AG, Mills C, Price DK. (1998) Partial deletion of both the spermine synthase gene and the Pex gene in the X-linked hypophosphatemic, gyro (Gy) mouse. Genomics 1548(3):289-95

Miller SA, Dykes DD, Polensky HF. (1988) A simple salting out procedure for extracting DNA from human nucleated cells. Nucleic Acids Res 16(3):1215

Pegg AE, Wechter R, Poulin R, Woster PM, Coward JK. (1989) Effect of S-adenosyl1,12-diamino-3-thio-9-azadodecane, a multisubstrate adduct inhibitor of spermine synthase, on polyamine metabolism in mammalian cells. Biochemistry 28(21):8446-53

Plenge RM, Hendrich BD, Schwartz C, Arena JF, Naumova A, Sapienza C, Winter RM, Willard HF. (1997) A promoter mutation in the XIST gene in two unrelated families with skewed X-chromosome inactivation. Nat Genet 17(3):353-6

Plenge RM, Stevenson RA, Lubs HA, Schwartz CE,Willard HF. (2002) Skewed Xchromosome inactivation is a common feature of $\mathrm{X}$-linked mental retardation disorders. Am J Hum Genet 71:168-173 
Saiki RK, Scharf S, Falooma F, Mullis KB, Horn GT. (1985) Enzymatic amplification of B-globin sequences and restriction site analysis for diagnosis of sickle cell anemia. Science 230:1350-1354

Seiler N, Knodgen B. (1985) Determination of amino acids by separation of their ion pairs with dodecyl sulphate. J Chromatogr 341(1):11-21

Snyder RD, Robinson A. (1969) Recessive sex-linked mental retardation in the absence of other recognizable abnormalities. Report of a family. Clin Pediatr (Phila) 8(11):669-74

Wiest L, Pegg AE. (1998) Assay of spermidine and spermine synthases. Methods Mol Biol 79:51-7

Wu H, Min J, Zeng H, McCloskey DE, Ikeguchi Y, Loppnau P, Michael AJ, Pegg AE, Plotnikov AN. (2008) Crystal Structure of Human Spermine Synthase: Implications of Substrate-Binding and Catalytic Mechanism. J Biol Chem [Epub ahead of print]

Zoumas-Morse C, Rock CL, Quintana EL, Neuhouser ML, Gerner EW, Meyskens FL Jr. (2007) Development of a polyamine database for assessing dietary intake. $J$ Am Diet Assoc 107(6):1024-7 


\section{Figura 1 A}

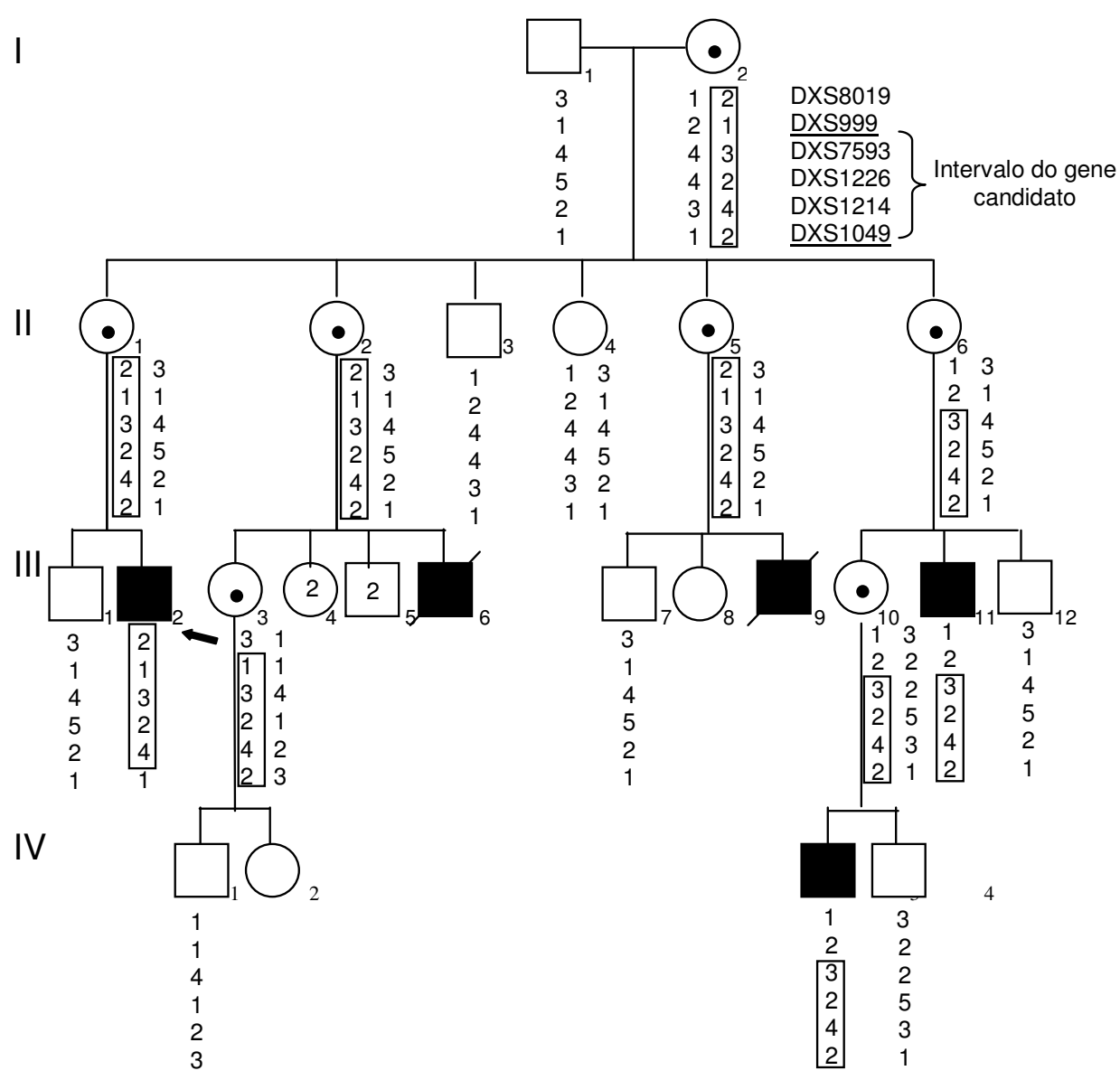

(A) Genealogia parcial da família. Símbolos em preto representam indivíduos afetados, e símbolos com pontos representam as mulheres portadoras do alelo deletério. O probando está indicado com uma seta. Os dados clínicos detalhados neste estudo foram obtidos de três pacientes (III-2, III-11 e IV-3), mas de acordo com relatos concedidos por membros da família, os pacientes III-6 e III-9 também sofriam de um profundo retardo mental com ausência de fala e graves convulsões. Os haplótipos dos marcadores do cromossomo X ligados ao gene da doença também são mostrados. O haplótipo em risco é indicado por um retângulo. Os indivíduos II-6 e III2 definem as bordas centromérica e telomérica do intervalo de ligação, respectivamente. 


\section{Figura 1 B}

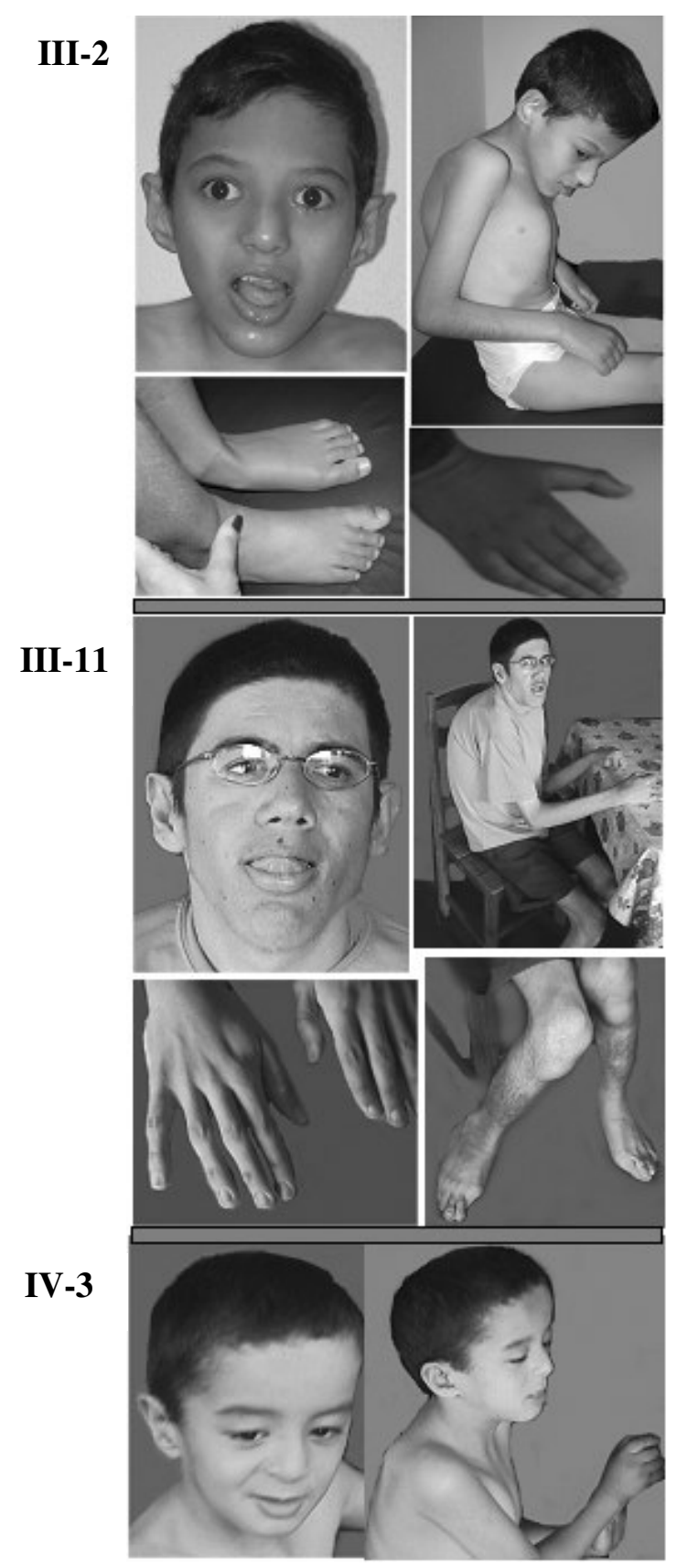

(B) Fotografias dos três indivíduos afetados do sexo masculino: III-2 (12 anos), III-11 (23 anos) e IV-3 (6 anos). 


\section{Figura 1 C e D}

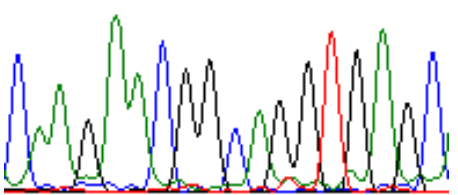

Indivíduo normal (III-1)

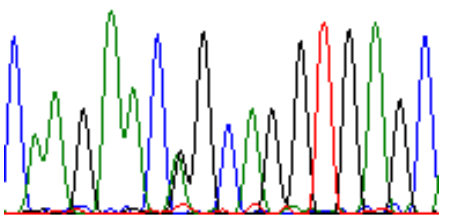

Mulher portadora (II-1)

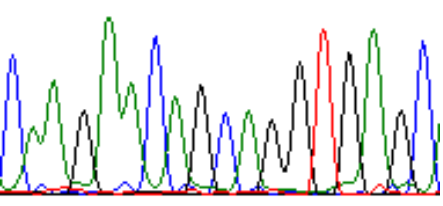

Indivíduo afetado (III-2)

(C) Cromatogramas da sequiência parcial do exon 2 do gene $S M S$ em um indivíduo normal do sexo masculino (III-1) da família, uma mulher portadora obrigatória da mutação (II-1) e um indivíduo afetado (III-2). A posição da mutação (c.267G>A) é indicada por um quadrado. Nota-se que embora essa mutação esteja localizada três pares de bases antes do sítio doador de splicing no intron 2 do gene $S M S$, isso não parece afetar o splicing do gene nos leucócitos periféricos dos pacientes afetados, uma vez que somente um fragmento de tamanho e intensidade normais proveniente do RTPCR foi observado na eletroforese em gel de agarose. Utilizando-se oligonucleotídeos localizados no exon 1 e 6 do gene, o seqüenciamento direto desse produto revelou splicing adequado nesta região.

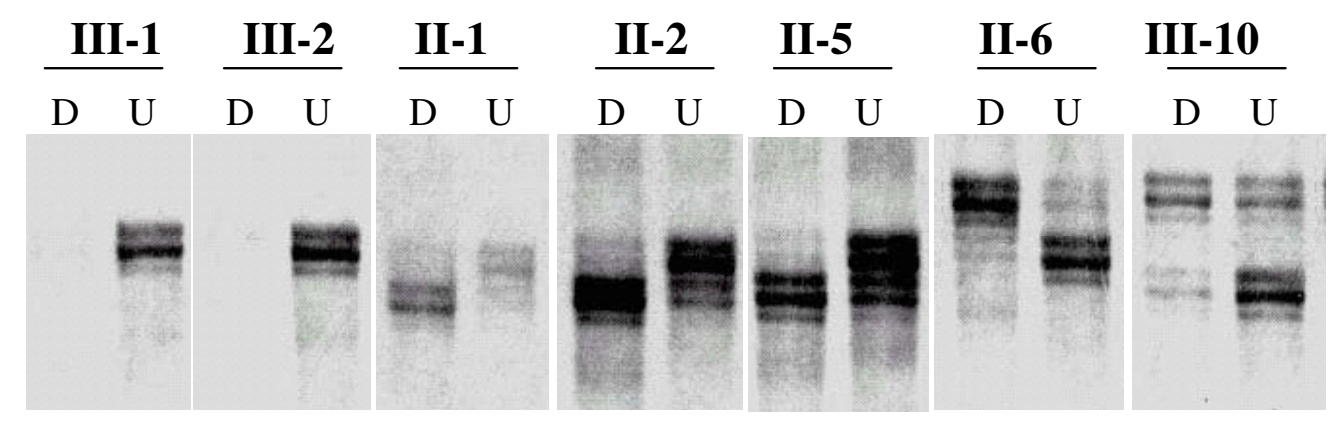

(D) Padrão de ICX observado em leucócitos de mulheres portadoras da mutação c. $267 \mathrm{G}>\mathrm{A}$ no gene $S M S$. O padrão de ICX foi investigado avaliando-se a metilação da repetição CAG do loco do receptor de andrógenos e utilizando DNA não-digerido e digerido com a enzima HpaII, indicados pelo $\mathrm{U}$ e $\mathrm{D}$, respectivamente. O DNA no cromossomo $\mathrm{X}$ inativo é resistente a digestão com HpaII e, assim, pode ser amplificado com oligonucleotídeos flanqueando o sítio de restrição na região da repetição CAG. O DNA do cromossomo $X$ ativo, como nos indivíduos III-1 e III-2, é clivado pela HpaII e assim nenhum produto de PCR é detectado nas frações D. O desvio de ICX em direção a um cromossomo ocorreu em II-1, II-2, II-5, II-6 e III-10. 


\title{
Figura 2 A e B
}

\begin{abstract}
Amostras
Atividade da espermina sintase

(pmol/h/mg de proteína)

Mulher normal

500

Paciente da primeira família com SRS

9

Mulher portadora II-6

634

Paciente IIII-2

$<1$

Paciente III-11

$<1$

Paciente IV-3

$<1$

(A) Níveis de atividade da SMS em linhagens de células linfoblastoídes em um indivíduo normal da população, um paciente afetado da primeira família descrita com SRS (mutação de splicing G>A na posição +5 a 5 do sítio de splicing no intron 4), uma mulher portadora (II-6) e três indivíduos afetados (III-2, III-11 e IV-3) da família aqui descrita (mutação p.G56S).
\end{abstract}

\section{Amostras Putrescina Espermidina Espermina Espermidina/Espermina (nmol/h/mg de proteína)}

$\begin{array}{lrrrr}\text { Paciente III-2 } & 0.32 & 11.09 & 2.83 & 3.92 \\ \text { Mulher normal } & 0.87 & 6.11 & 9.18 & 0.66\end{array}$

(B) Conteúdo das poliaminas presentes em linhagens de células linfoblastóides de um indivíduo normal da população e no indivíduo do sexo masculino III-2 da família aqui descrita (mutação p.G56S). Espermidina é sintetizada a partir da putrescina pela enzima espermidina sintase e espermidina é adicionalmente metabolizada para espermina pela espermina sintase (SMS). 


\section{Figura 2 C}

\begin{tabular}{ll} 
& \multicolumn{2}{c}{ G56S } \\
humano & jYLATYTNKNGSFANLRIYPH \\
galinha & jYLATYIKKNGSFANLRIHPH \\
vaca & jYLATYINKNGSFANLRIYPH \\
lagarto & jYLATYVNKNGSFANLRIYPH \\
cachorro & jYLATYINKNGSFANLRIYPH \\
rato & jYLATYTNKNGSFANLRIYPH \\
camundongo & jYLATYTNKNGSFANLRIYPH \\
marsupial & jYLATYINKNGSFASLRIYPH \\
sapo & jYLATYTGKKGSFATVRIYPH \\
peixe & jYLATLVGKHGRLALLRVHSH
\end{tabular}

(C) Alinhamento das proteínas SMS de vertebrados. Somente as seqüências parciais, correspondendo aos resíduos 46 a 66 da proteína SMS humana, são mostradas. A mutação de troca de aminoácido identificada na família brasileira e sua posição são indicadas pela seta. O resíduo de Glicina $(\mathrm{G})$ na posição 56 é altamente conservado e está delineado por uma caixa. 


\section{Figura 3 A e B}

(A)
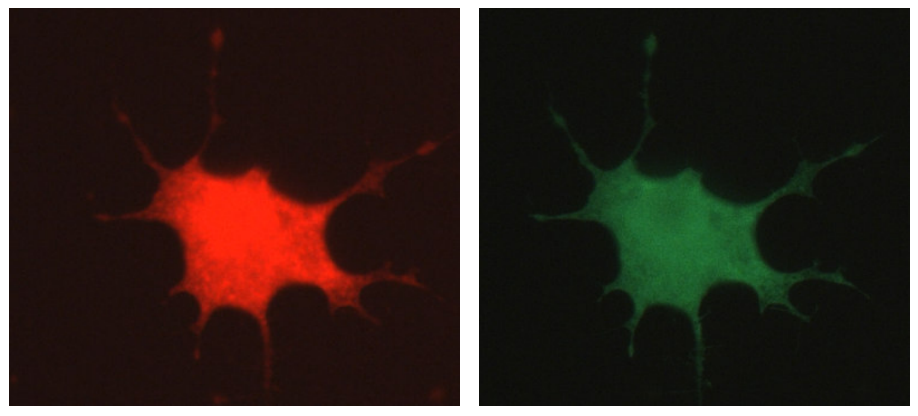

(B)
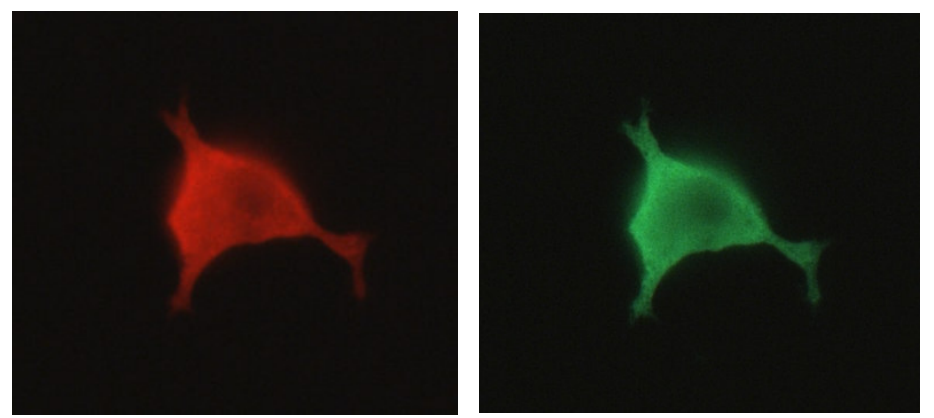

(A) Fotografia das células neuronais PC-12 transfectadas com o vetor contendo o cDNA de toda a região codificadora da proteína SMS humana selvagem.

(B) Fotografia das células neuronais PC-12 transfectadas com o vetor contendo o cDNA de toda a região condificadora da proteína SMS humana com a mutação c. $267 \mathrm{G}>\mathrm{A}$.

\section{Anticorpos primários:}

- anti-myc policlonal (coelho) (Clontech)

\section{Anticorpos secundários:}

- Alexa Fluor 594 anti-coelho

(florescência vermelha) (Molecular probes)

- anti-V5 monoclonal (camundongo) (Invitrogen) - Alexa Fluor 488 anti-camundongo (florescência verde) (Molecular probes) 
Tabela 1. Sequiência dos oligonucleotídeos iniciadores utilizados nas reações de RTPCR para análise do gene SMS. Também está mostrado o tamanho do produto amplificado.

\begin{tabular}{|l|l|l|c|}
\hline & \multicolumn{1}{|c|}{ Iniciador Forward $\left(\mathbf{5}^{\prime} \rightarrow \mathbf{3}\right.$ ') } & \multicolumn{1}{|c|}{ Iniciador Reverse $\left(\mathbf{5}^{\prime} \rightarrow \mathbf{3}^{\prime}\right)$} & $\begin{array}{c}\text { Tamanho do } \\
\text { produto }(\mathbf{p b})\end{array}$ \\
\hline cDNA 1 & AGCACACTCCCAGCCGGC & GTCTCCACCTCCCAGAATGA & 697 \\
\hline CDNA 2 & GGCAGAGAGTGATTTGGCATA & GCATATGGAGGTCAGGAAGG & 648 \\
\hline
\end{tabular}

Tabela 2. Sequiência dos oligonucleotídeos iniciadores utilizados para amplificação e análise do exon 2 do gene $S M S$ (a partir de DNA genômico) por PCR e seqüenciamento. Também está mostrado o tamanho do produto amplificado.

\begin{tabular}{|l|l|c|c|}
\hline & \multicolumn{1}{|c|}{ Iniciador Forward $\left(\mathbf{5}^{\prime} \rightarrow \mathbf{3}^{\prime}\right)$} & Iniciador Reverse $\left(\mathbf{5}^{\prime} \rightarrow \mathbf{3}^{\prime}\right)$ & $\begin{array}{c}\text { Tamanho do } \\
\text { produto }(\mathbf{p b})\end{array}$ \\
\hline $\begin{array}{l}\text { SMS } \\
\text { 2F/2R }\end{array}$ & CCTTCTTCCCCTTGTTCTCC & TCTGTCACCCTCTCTGCTCA & 215 \\
\hline
\end{tabular}

Tabela 3. Seqüência dos oligonucleotídeos iniciadores utilizados para amplificação do exon 2 do gene SMS (a partir de DNA genômico) por PCR e análise em alta resolução da temperatura de melting. Também está mostrado o tamanho do produto amplificado.

\begin{tabular}{|l|l|l|c|}
\hline & \multicolumn{1}{|c|}{ Iniciador Forward $\left(\mathbf{5}^{\prime} \rightarrow \mathbf{3}^{\prime}\right)$} & \multicolumn{1}{|c|}{ Iniciador Reverse $\left(\mathbf{5}^{\prime} \rightarrow \mathbf{3}^{\prime}\right)$} & $\begin{array}{l}\text { Tamanho do } \\
\text { produto }(\mathbf{p b})\end{array}$ \\
\hline $\begin{array}{l}\text { SMS 2 } \\
\text { GGC }\end{array}$ & GTGGTCTGCGTTGCCTTTCCTT & $\begin{array}{l}\text { ACCCCCATCCTCCACTCTGTC } \\
\text { AC }\end{array}$ & 436 \\
\hline
\end{tabular}


Tabela 4. Seqüência dos oligonucleotídeos iniciadores utilizados para as análises de PCR em Tempo Real. Também está mostrado o tamanho do produto amplificado.

\begin{tabular}{|l|l|l|c|}
\hline \multicolumn{1}{|c|}{ Gene } & \multicolumn{1}{|c|}{ Iniciador Forward $\left(\mathbf{5}^{\prime} \rightarrow \mathbf{3}^{\prime}\right)$} & \multicolumn{1}{|c|}{ Iniciador Reverse $\left(\mathbf{5}^{\prime} \rightarrow \mathbf{3}^{\prime}\right)$} & $\begin{array}{c}\text { Tamanho do } \\
\text { produto }(\mathbf{p b})\end{array}$ \\
\hline SMS & CCCACATGGATTGGTGTTTGCT & GCTCCTCCTCGCACTATGG & 165 \\
\hline ACTB & GCGTGACATTAAGGAGAAG & GAAGGAAGGCTGGAAGAG & 173 \\
\hline POLR2A & GCACCACGTCCAATGACAT & GTGCGGCTGCTTCCATAA & 267 \\
\hline GAPDH & GAAGGTGAAGGTCGGAGTC & GAAGATGGTGATGGGATTTC & 226 \\
\hline
\end{tabular}

Tabela 5. Seqüências dos oligonucleotídeos iniciadores utilizados para amplificar toda a região codificadora das proteínas SMS selvagem e SMS com a mutação p.G56S para as clonagens no vetor de expressão em células de mamíferos pBudCE4.1. Também está mostrado o tamanho do produto amplificado.

\begin{tabular}{|l|l|l|c|}
\hline & \multicolumn{1}{|c|}{ Iniciador Forward $\left(\mathbf{5}^{\prime} \rightarrow \mathbf{3}^{\prime}\right)$} & \multicolumn{1}{|c|}{ Iniciador Reverse $\left(\mathbf{5}^{\prime} \rightarrow \mathbf{3}^{\prime}\right)$} & $\begin{array}{l}\text { Tamanho do } \\
\text { produto }(\mathbf{p b})\end{array}$ \\
\hline $\begin{array}{l}\text { Sítio A (V5) } \\
\text { KnnI/XhoI }\end{array}$ & $\begin{array}{l}\text { GCTGGTACCCACCATGGCA } \\
\text { GCAGCACGGCAC }\end{array}$ & $\begin{array}{l}\text { GCCTCGAGGCGGGTTTAGCT } \\
\text { TTCTTCCAAAC }\end{array}$ & 1101 \\
\hline $\begin{array}{l}\text { Sítio B }(\text { myc) } \\
\text { HindIII/BamHI }\end{array}$ & $\begin{array}{l}\text { CGCTAAGCTTCACCATGGC } \\
\text { A GCAGCACGGCAC }\end{array}$ & $\begin{array}{l}\text { GCGGATCCGGGTTTAGCTTTC } \\
\text { TTCCAAAC }\end{array}$ & 1101 \\
\hline
\end{tabular}

Tabela 6. Esquema das transfecções realizadas com os plasmídeos contendo os cDNAs da proteína SMS humana selvagem (GenBank: NM_004595) e mutada (p.G56S).

pBudCE4.1 + SMSselv +SMSselv (controle positivo)

pBudCE4.1 + SMSmut + SMSmut 
Tabela 7. Resumo dos fenótipos observados nos meninos afetados da família Brasileira em estudo. Os dados clínicos detalhados para este estudo foram obtidos de três pacientes (III-2, III-11 e IV-3). É apresentado também um resumo das características clínicas observadas nos pacientes da família originalmente descrita com SRS.

\begin{tabular}{|c|c|c|c|c|c|}
\hline Características clínicas & III-2 & III-11 & IV-3 & $\begin{array}{l}\text { Resumo (No. Afetados } \\
\text { do sexo masculino com } \\
\text { sinal clínico/ No. Total } \\
\text { afetados do sexo } \\
\text { masculino analisados) }\end{array}$ & $\begin{array}{l}\text { Primeira família descrita } \\
\text { com SRS (No. Afetados do } \\
\text { sexo masculino com sinal } \\
\text { clínico/ No. Total afetados d } \\
\text { sexo masculino analisados) }\end{array}$ \\
\hline Idade (anos) & 12 & 23 & 6 & $6-23$ & $19-41$ \\
\hline Peso (kg) (centil) & $20,1\left(<3^{\circ}\right)$ & $55\left(25-50^{\circ}\right)$ & $23\left(50-75^{\circ}\right)$ & $1 / 3<3^{o}$ & $4 / 5<5^{\circ}$ \\
\hline Altura $(\mathrm{cm})($ centil $)$ & $128\left(<3^{\circ}\right)$ & $\begin{array}{l}\text { Não pode ser } \\
\text { avaliado }\end{array}$ & $106\left(<3^{\circ}\right)$ & $2 / 2<3^{\circ}$ & 2/2 (Elevada) \\
\hline Retardo Mental & Profundo & Grave & Profundo & $3 / 3$ & 5/5 (Médio a moderado) \\
\hline \multicolumn{6}{|l|}{ Anormalidades Neuromusculares } \\
\hline Convulsões & + & + & + & $3 / 3$ & $3 / 6$ \\
\hline Anormalidade na marcha & + & + & + & $3 / 3$ & $1 / 5$ \\
\hline \multicolumn{6}{|l|}{ Cabeça } \\
\hline Circunferência da cabeça (cm) (centil) & $52\left(50^{\circ}\right)$ & $56\left(50^{\circ}\right)$ & $53,5\left(50-75^{\circ}\right)$ & $3 / 3\left(50-75^{\circ}\right)$ & $6 / 6\left(>50^{\circ}\right)$ \\
\hline Assimetria da boca e/ou órbita & - & - & - & $0 / 3$ & $4 / 5$ \\
\hline Prognatismo mandibular médio & + & + & + & $3 / 3$ & $1 / 5$ \\
\hline $\begin{array}{l}\text { Lábio inferior proeminente, lábio superior } \\
\text { mais fino }\end{array}$ & + & + & + & $3 / 3$ & $5 / 5$ \\
\hline Filtro curto & + & + & + & $3 / 3$ & $0 / 5$ \\
\hline Palato anormal & + & Desconhecido & Desconhecido & $1 / 1$ & $3 / 5$ \\
\hline Orelhas anormais & + & + & - & $2 / 3$ & $0 / 5$ \\
\hline Miopia elevada & + & + & - & $2 / 3$ & $0 / 5$ \\
\hline
\end{tabular}


Habitus/esqueleto

Magro, com hipoplasia muscular

\section{Cifoescoliose}

Pectus carinatum

Pectus excavatum

Osteoporose

Mãos e pés

Mãos e dedos longos

Dedos hiperextensíveis

Pés longos e grandes
$+$

$+$

$+$

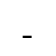

$+$

$-$
$+$

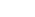

Desconhecido

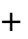

Não pode ser avaliado
$5 / 5$

$4 / 5$

$0 / 5$

$3 / 5$

$4 / 4$

$5 / 5$

$4 / 5$

$3 / 3$

$+=$ Presente $;-=$ Ausente

a = A família original com SRS foi descrita por Snyder e Robinson (1969) [1]. Ela foi reavaliada por Arena et al. em 1996 [2], os quais descreveram mais detalhadamente o quadro clínico dos cinco indivíduos adultos do sexo masculino e adicionaram a descrição de um menino de 2 anos de idade. Embora os dados clínicos da infância não sejam apresentados nesta Tabela, todos os indivíduos afetados apresentavam um atraso no desenvolvimento. 


\title{
Capítulo 4
}

\section{Análise de $A R H G E F 9$, gene codificador da proteína colibistina, em pacientes com Hiperecplexia e em pacientes com Retardo Mental associado com Epilepsia.}

\author{
Alencastro, $\mathrm{G}^{1}$; Sertié, $\mathrm{AL}^{1}$; Casella, EB ${ }^{2}$; Kok, $\mathrm{F}^{2}$; Lopes, I3 ; Manreza, $\mathrm{MLG}^{2}$, \\ Passos-Bueno, $\mathrm{MR}^{1}$. \\ ${ }^{1}$ Centro de Estudos do Genoma Humano, Departamento de Genética e Biologia \\ Evolutiva, Instituto de Biociências, Universidade de São Paulo, SP. ${ }^{2}$ Hospital das \\ Clínicas da Faculdade de Medicina da Universidade de São Paulo. ${ }^{3}$ Universidade de \\ Campinas. \\ e-mail: gus_alencastro@hotmail.com \\ Palavras-chave: colibistina (gene ARHGEF9), sinapses inibitórias, hiperecplexia, \\ epilepsia idiopática, retardo mental.
}

Apoio financeiro: FAPESP e CNPq 


\section{Resumo}

Introdução: a proteína colibistina pertence à família das GEFs, proteínas que ativam Rho-like GTPases. Colibistina é responsável pela localização dos receptores de estímulos inibitórios de $\mathrm{GABA}_{\mathrm{A}}$ na membrana neuronal pós-sináptica por meio da interação com a proteína gefirina. Mutações no gene codificador da colibistina (ARHGEF9) foram encontradas em três pacientes que possuem em comum retardo mental associado com outras anormalidades neurológicas, tais como hiperecplexia e epilepsia, e comportamentais, tais como e agressão e ansiedade. Objetivo: triar mutações na região codificadora e bordas exon/intron de ARHGEF9 em pacientes Brasileiros com hiperecplexia e com retardo mental associado com epilepsia. Material e Métodos: a análise do gene ARHGEF9 nos pacientes com hiperecplexia (6 pacientes) e com retardo mental associado com epilepsia (22 pacientes) foi realizada utilizando-se as técnicas de dHPLC e seqüenciamento. Resultados e Discussão: nenhuma alteração patogênica foi encontrada no gene ARHGEF9 nos 28 pacientes estudados. Contudo, o número de pacientes analisados neste trabalho foi muito pequeno. Se reunirmos nossos pacientes com hiperecplexia aos descritos na literatura, a frequiência de mutação em ARHGEF9 nesses pacientes é de aproximadamente 2,6\%. Ainda, julgamos interessante a análise de ARHGEF9 em um número maior de pacientes com hiperecplexia e retardo mental associado com epilepsia. 


\section{Abstract}

Introduction: the collybistin protein is a member of the GEF family, which activated Rho-like GTPases. Collybistin is responsible by the localization of major $\mathrm{GABA}_{\mathrm{A}}$ inhibitory receptor subtype on the postsynaptic neuronal membrane through interaction with the gephyrin protein. Mutations in the gene enconding collybistin (ARHGEF9) were described in three patients who presented mental retardation associated with others neurological abnormalities, such as hyperekplexia and epilepsy, and behavior abnormalities, such as aggression and anxiety. Objective: to investigate the presence of mutations in the open reading frame and exons/introns boundaries of the ARHGEF9 gene in Brazilian patients with hyperekplexia and mental retardation associated with epilepsy. Material e Methods: the screening for mutations in the patients with hyperekplexia (6 patients) and mental retardation associated with epilepsy (22 patients) was made by dHPLC and sequencing analysis. Results and Discussion: no pathogenic alterations were found in the 28 studied patients. However, the number of analyzed patients was very small. If we take into account all hyperekplexia patients analyzed for ARHGEF9 mutations, including our Brazilian patients, the frequency of mutations in this gene associated with hyperekplexia is 2.6\%. In addition, the possibility remains that additional mutations in ARHGEF9 may contribute to other cases of hyperekplexia and mental retardation associated with epilepsy. 


\section{Introdução}

Diversos estudos mostraram que proteínas associadas a receptores de neurotransmissores são cruciais para a correta distribuição e ancoramento desses receptores nas membranas pós-sinápticas, o que garante a transmissão sináptica eficiente (Kneussel \& Betz, 2000; Kim \& Sheng, 2004). A proteína gefirina é conhecida por desempenhar um papel fundamental no agrupamento dos receptores de glicina contendo a subunidade $\beta$ e de certos subtipos de receptores de $\mathrm{GABA}_{\mathrm{A}}$ (compostos pelas subunidades $\alpha_{2}$ e $\gamma_{2}$ ), os quais são importantes neurotransmissores inibidores do sistema nervoso central (SNC). A ancoragem e agrupamento desses receptores na membrana das células nervosas parecem ser mediados pela interação de gefirina com proteínas reguladoras ou constituintes do citoesqueleto como tubulina (Kirsch et al., 1991), profilina (Mammoto et al., 1998), cadeias leves de dineína 1 e 2 (Fuhrmann et al., 2002), Mena/VASP (Giesemann et al., 2003) e com a proteína colibistina (Kins et al., 2000).

\section{Proteína colibistina}

A proteína colibistina pertence à família das GEFs (guanine nucleotide exchange factors), as quais ativam Rho-like GTPases (Kins et al., 2000). O gene humano que codifica a colibistina, conhecido como ARHGEF9 (MIM\# 300429), apresenta 11 exons e está mapeado no cromossomo Xq11.2, possuindo expressão neuro-específica (Harvey et al., 2004).

Estudos funcionais in vitro com as proteínas gefirina e colibistina superexpressas em células humanas HEK 293 (human embryonic kidney) revelaram que colibistina desempenha um papel importante nas cascatas de sinalização que promovem rearranjo do citoesqueleto celular, agrupamento e recrutamento de gefirina, e conseqüentemente de receptores de glicina e $\mathrm{GABA}_{\mathrm{A}}$ para junto da membrana plasmática (Kins et al., 2000; Harvey et al., 2004). Assim, esses resultados sugeriram que colibistina atuaria na localização de gefirina e de receptores de glicina e $\mathrm{GABA}_{\mathrm{A}}$ nos sítios pós-sinápticos inibidores. Estudos mais recentes demonstraram que camundongos deficientes para colibistina apresentam perda de agrupamentos da proteína gefirina e de certos receptores $\mathrm{GABA}_{\mathrm{A}}$ (compostos pelas subunidades $\alpha 2 \mathrm{e}$ 
$\gamma_{2}$ ) na membrana pós-sináptica de neurônios do hipocampo e da amígdala basolateral, ansiedade e deficiência de aprendizado espacial (Papadopoulos et al., 2007 e 2008).

Quando iniciamos este estudo em 2003, nenhuma mutação patogênica havia sido descrita no gene ARHGEF9. Contudo, consideramos ARHGEF9 candidato para a etiologia de doenças neurológicas como hiperecplexia, epilepsia idiopática e retardo mental, conforme discutido a seguir.

Deficiência na neurotransmissão glicinérgica havia sido associada com hiperecplexia. Mutações patogênicas nos genes codificadores das subunidades $\alpha 1$ (GLRA1) (Shiang et al., 1993; Rees et al., 2002) e $\beta$ (GLRB) (Rees et al., 2002) dos receptores de glicina, no gene codificador do transportador pré-sináptico de glicina (SLC6A5) (Rees et al., 2006), e no gene codificador da proteína gefirina (GPHN) (Rees et al., 2003) foram identificadas em pacientes com hiperecplexia. A hiperecplexia (OMIM \#149400), também conhecida como "Doença do Susto" ou "Síndrome da Pessoa Rígida", é uma desordem neuronal rara, com prevalência ainda desconhecida, caracterizada por uma resposta exagerada ao susto, hipertonia neonatal, e convulsões mioclônicas noturnas (Zhou et al., 2002).

Mutações patogênicas em genes codificadores de certas subunidades de receptores $\mathrm{GABA}_{\mathrm{A}}$ foram associadas com diferentes formas familiais de epilepsias idiopáticas: mutações no gene da subunidade $\alpha 1$ de receptores $\mathrm{GABA}_{\mathrm{A}}$ foram encontradas em pacientes com epilepsia mioclônica juvenil (Cossete et al., 2002), e em pacientes com epilepsia ausência da infância (Maljevic et al., 2006); mutações no gene da subunidade $\gamma 2$ de receptores $\mathrm{GABA}_{\mathrm{A}}$ foram identificadas em pacientes com epilepsia generalizada associada a convulsões febris "mais" (GEFS+) (Baulac et al., 2001), em pacientes com epilepsia ausência da infância associada com convulsão febril (Wallace et al., 2001; Kananura et al., 2002; Marini et al., 2003), e em pacientes com GEFS+ e epilepsia mioclônica na infância (Harkin et al., 2001).

Mutações patogênicas em genes responsáveis por codificar proteínas que atuam diretamente como reguladoras ou efetoras das funções das Rho-like GTPases foram identificadas em pacientes com retardo mental. Esses genes incluem: OPHN1 (codifica uma proteína da família das RhoGAP - Rho-GTPase-activating protein, ou seja, atua na desativação de proteínas Rho-like GTPases), ARHGEF6 (codifica uma 
proteína GEF que ativa Rho-like GTPases), PAK3 (codifica uma proteína da grande família das PAK - p21-activating kinase, as quais são ativadas por Rho-like GTPases), TM4SF2 (codifica uma proteína responsável pela ativação de proteínas da família Rac e Rho-like GTPases), FGDl (codifica uma proteína GEF que regula Rac e Cdc42), e OCRL1 (codifica uma proteína que interage com Rac1) (revisado em Vaillend et al., 2008).

Assim, como já era conhecido que a proteína colibistina estava envolvida na localização de gefirina, de receptores de glicina e de certos subtipos de receptores $\mathrm{GABA}_{\mathrm{A}}$ nas membranas pós-sinápticas neuronais, julgamos que mutações no gene ARHGEF9 poderiam estar associadas com deficiência da neurotransmissão inibitória e assim causar hiperecplexia e/ou epilepsia. Ainda, como colibistina atua como GEF, julgamos que mutações em ARHGEF9 poderiam ocasionar alterações na ativação de Rho-like GTPases, levando ao retardo mental.

Portando, o presente trabalho teve como objetivo analisar o gene ARHGEF9 em pacientes brasileiros portadores de hiperecplexia e de retardo mental associado com epilepsia.

\section{Pacientes e Métodos}

\section{Pacientes}

Foi analisado um total de 28 pacientes: 6 pacientes com hiperecplexia (quatro crianças do sexo masculino - idades 4 a 6 anos - e duas crianças do sexo feminino idade 2 e 10 anos) e 22 pacientes do sexo masculino com retardo mental associado com epilepsia. Os pacientes foram encaminhados para estudo molecular no Centro de Estudos do Genoma Humano (Instituto de Biociências da Universidade de São Paulo), ou tiveram suas amostras de sangue ou DNA enviadas pelo correio. Os Doutores Erasmo Barbante Casella e Fernando Kok (Hospital das Clínicas da Faculdade de Medicina da Universidade de São Paulo - HC-FMUSP) enviaram as amostras de pacientes com hiperecplexia. As Doutoras Iscia Lopes (Universidade de Campinas) e Maria Luiza Giraldes de Manreza (HC-FMUSP) enviaram as amostras de pacientes com retardo mental associado com epilepsia. 
O consentimento de cada participante ou de seus pais ou responsáveis foi obtido antes de sua participação neste estudo. Este estudo foi aprovado pelo Comitê de Ética do Instituto de Biociências da Universidade de São Paulo, Brasil (Parecer 458/CEP) e pela Comissão de Ética para Análise de Projetos de Pesquisa - Cappesq da Diretoria Clínica do Hospital das Clínicas da FMUSP.

\section{Extração de DNA}

O DNA dos pacientes foi extraído a partir de amostras de sangue periférico segundo procedimentos baseados no protocolo descrito por Miller et al. (1988).

\section{PCR}

Utilizando DNA genômico dos indivíduos afetados, cada exon e as bordas exon/intron do gene ARHGEF9 foram amplificados pela PCR (polymerase chain reaction - Saiki et al., 1985), utilizando os termocicladores da PTC-150 MJ Research e da Perkin Elmer. As sequiências dos oligonucleotídeos utilizados estão descritas na Tabela 1.

\section{dHPLC}

Os produtos da PCR (denominados amplicons) foram analisados pela técnica de dHPLC (denaturing high-performance liquid chromatography) (Oefner \& Underhill, 1995) utilizando o aparelho WAVE® (Transgenomic). As temperaturas de análise dos amplicons do gene ARHGEF9 foram avaliadas utilizando o programa Navigator (http://insertion.stanford.edu/melt.html) e estão descritas na Tabela 2. As amostras analisadas que apresentaram um padrão diferente dos controles foram seqüenciadas.

\section{Seqüenciamento}

O produto da PCR de cada amplicon do gene ARHGEF9 foi purificado com o auxílio das enzimas Exonuclease I (USB) e Fosfatase Alcalina (Amersham Biosciences) e então foi seqüenciado em dois aparelhos distintos: seqüenciador MegaBACE ${ }^{T M} 1000$ DNA Analysis Systems (Amersham Biosciences), usando o kit Premix (Amersahm Biosciences) e o seqüenciador ABI Prism ${ }^{T M}$ Sequencer 377 
(versão 3.0 Applied Biosystems), usando o kit BigDye Terminator Cycle Sequencing ( $P E$ Biosystems, Foster City, CA). As seqüências foram analisadas utilizando-se o software da Sequencher (www.sequencher.com) e BioEdit (www.mbio.ncsu.edu/BioEdit/bioedit.html).

\section{Resultados e Discussão}

Analisamos os 11 exons e as bordas exons/intron do gene ARHGEF9 em um total de 28 pacientes brasileiros: 6 pacientes com hiperecplexia e 22 pacientes do sexo masculino com retardo mental associado com epilepsia. Não identificamos nenhuma mutação patogênica.

Após termos iniciado este trabalho, três mutações patogênicas foram descritas no gene ARHGEF9, resultando em quadros clínicos diversos e com gravidade variável. Harvey et al. (2004) descreveram uma mutação de substituição de aminoácido no domínio SH3 da colibistina, p.G55A, em um menino com retardo mental grave, hiperecplexia e epilepsia de difícil controle, que teve morte prematura aos 4 anos de idade. Marco et al. (2008) descreveram uma paciente com uma inversão paracêntrica no cromossomo $\mathrm{X}$, onde um dos pontos de quebra rompia o gene ARHGEF9 (e o outro ponto de quebra era em um deserto gênico), e que apresentava quadro clínico mais leve, incluindo retardo mental moderado e hiperestimulação sensorial. Kalscheuer et al. (2008) descreveram uma paciente com uma translocação balanceada entre o cromossomo $\mathrm{X}$ e o 18 , na qual o ponto de quebra no cromossomo X rompia o gene ARHGEF9 (e o ponto de quebra no cromossomo 18 não rompia gene), com quadro clínico grave, incluindo retardo mental profundo, epilepsia, alterações no sono, ansiedade, comportamento agressivo e dismorfismo facial. Estas últimas pacientes apresentavam inativação completa do cromossomo X normal.

É interessante ressaltar que estudos funcionais demonstraram que os dois pacientes com quadros clínicos mais graves (Harvey et al., 2004 e Kalscheuer et al., 2008) são portadores de mutações no gene $A R H G E F 9$ associadas com a produção de proteínas colibistinas mutantes com aparente ganho de função, que seqüestram agregados da proteína gefirina e de receptores $\mathrm{GABA}_{\mathrm{A}}$ dos sítios sinápticos. Já a

paciente com quadro clínico relativamente mais brando (Marco et al., 2008) é 
portadora de uma mutação de perda de função e apresenta apenas níveis bastante reduzidos de expressão da colibistina proveniente do alelo normal (apesar dos estudos de inativação do cromossomo $\mathrm{X}$ terem sugerido que a paciente apresenta inativação completa do cromossomo X normal).

Epilepsia e retardo mental são doenças de etiologia muito heterogêneas e bastante freqüentes na população. Conforme discutido na introdução, julgamos que um grupo de pacientes interessantes para analisar o gene ARHGEF9 seria o de pacientes do sexo masculino (pois o gene se localiza no cromossomo $\mathrm{X}$ ) portadores de retardo mental associado com epilepsia. Nosso grupo amostral analisado neste trabalho é, sem dúvida, muito pequeno. Porém, infelizmente, não conseguimos aumentar esse número de pacientes, pois nossa colaboração com as médicas colaboradoras não se deu de forma satisfatória. As três mutações patogênicas encontradas em ARHGEF9 estão associadas com retardo mental, sendo que destas, duas também estão associadas com epilepsia (Harvey et al., 2004; Marco et al., 2008; Kalscheuer et al., 2008). Marco et al. (2008) também analisaram o gene ARHGEF9 em um total 576 pacientes do sexo masculino com retardo mental ligado ao cromossomo X não-sindrômico (99 casos familiais e 477 casos isolados) e não encontraram nenhuma alteração patogênica. Esses resultados sugerem que mutações em ARHGEF9 são relativamente raras em pacientes com retardo mental nãosindrômico. Contudo, nenhuma triagem de mutação em ARHGEF9 foi descrita em pacientes portadores de retardo mental associado à epilepsia. Assim, é possível que mutações novas em ARHGEF9 sejam identificadas nesses pacientes.

Uma vez que hiperecplexia é uma doença rara, tivemos dificuldade em reunir mais do que 6 pacientes. É interessante ressaltar que Harvey et al. (2004) triaram mutação na região codificadora do gene ARHGEF9 em 32 pacientes com hiperecplexia (que não apresentavam mutações nos genes GLRA1, GLRB e GPHN) e identificaram um paciente com mutação patogênica neste gene. Se agruparmos nossos pacientes aos pacientes analisados por Harvey et al. a freqüência de mutação encontrada em ARHGEF9 é de aproximadamente 2,6\% (1 mutação/38 pacientes). Portando, podemos concluir que o número de pacientes com hiperecplexia que analisamos neste trabalho é pequeno. Contudo, é possível que alguns de nossos pacientes, assim como alguns dos pacientes analisados por Harvey et al. possam 
apresentar uma mutação patogênica em uma região não analisada de ARHGEF9, como por exemplo, na região promotora do gene.

\section{Agradecimentos}

Gostaríamos de agradecer os pacientes e as famílias pela cooperação e vontade de participar nesta pesquisa. Agradecemos também a Constância G. Urbani pela assistência secretarial e Marta Canovas pelas contribuições técnicas. Este trabalho foi financiado por bolsas da Fundação de Amparo à Pesquisa do Estado de São Paulo

(FAPESP) e do Conselho Nacional de Desenvolvimento Científico e Tecnológico (CNPq). 


\section{Referências Bibliográficas}

Baulac S, Huberfeld G, Gourfinkel-An I, Mitropoulou G, Beranger A, Prud'homme JF, Baulac M, Brice A, Bruzzone R, LeGuern E. (2001) First genetic evidence of $\mathrm{GABA}(\mathrm{A})$ receptor dysfunction in epilepsy: a mutation in the gamma2subunit gene. Nat Genet 28(1):46-8

Cossette P, Liu L, Brisebois K, Dong H, Lortie A, Vanasse M. (2002) Mutation of GABRA1 in an autosomal dominant form of juvenile myoclonic epilepsy. Nature Genet 31:184-189

Fuhrmann JC, Kins S, Rostaing P, El Far O, Kirsch J, Sheng M, Triller A, Betz H, Kneussel M. (2002) Gephyrin interacts with Dynein light chains 1 and 2, components of motor protein complexes. J Neurosci 22(13):5393-402

Giesemann T, Schwarz G, Nawrotzki R, Berhorster K, Rothkegel M, Schluter K, Schrader N, Schindelin H, Mendel RR, Kirsch J, Jockusch BM. (2003) Complex formation between the postsynaptic scaffolding protein gephyrin, profilin, and Mena: a possible link to the microfilament system. J Neurosci 23(23):8330-9

Harkin LA, Bowser DN, Dibbens LM, Singh R, Phillips F, Wallace RH, Richards MC, Williams DA, Mulley JC, Berkovic SF, Scheffer IE, Petrou S. (2002) Truncation of the GABA(A)-receptor gamma2 subunit in a family with generalized epilepsy with febrile seizures plus. Am J Hum Genet 70(2):530-6.

Harvey K, Duguid IC, Alldred MJ, Beatty SE, Ward H, Keep NH, Lingenfelter SE, Pearce BR, Lundgren J, Owen MJ, Smart TG, Luscher B, Rees MI, Harvey RJ. (2004) The GDP-GTP exchange factor collybistin: an essential determinant of neuronal gephyrin clustering. J Neurosci 24(25): 5816-26

Kalscheuer VM, Musante L, Fang C, Hoffmann K, Fuchs C, Carta E, Deas E, Venkateswarlu K, Menzel C, Ullmann R, Tommerup N, Dalprà L, Tzschach A, Selicorni A, Lüscher B, Ropers HH, Harvey K, Harvey RJ. (2008) A balanced chromosomal translocation disrupting ARHGEF9 is associated with epilepsy, anxiety, aggression, and mental retardation. Hum Mutat [Epub ahead of print]

Kananura C, Haug K, Sander T, Runge U, Gu W, Hallmann K, Rebstock J, Heils A, Steinlein OK. (2002) A splice-site mutation in GABRG2 associated with childhood absence epilepsy and febrile convulsions. Arch Neurol 59(7):1137-41

Kim E, Sheng M. (2004) PDZ domain proteins of synapses. Nat Rev Neurosci 5: 771781

Kins S, Betz H, Kirsch J. (2000) Collybistin, a newly identified brain-specific GEF, induces submembrane clustering of gephyrin. Nat Neurosci 3(1):22-9 
Kirsch J, Langosch D, Prior P, Littauer UZ, Schmitt B, Betz H. (1991) The 93-kDa glycine receptor-associated protein binds to tubulin. $J$ Biol Chem 266(33):22242-5

Kneussel M, Betz H. (2000) Receptors, gephyrin and gephyrin-associated proteins: novel insights into the assembly of inhibitory postsynaptic membrane specializations. J Physiol 525 (Pt 1):1-9

Maljevic S, Krampfl K, Cobilanschi J, Tilgen N, Beyer S, Weber YG, Schlesinger F, Ursu D, Melzer W, Cossette P, Bufler J, Lerche H, Heils A. (2006) A mutation in the GABA(A) receptor alpha(1)-subunit is associated with absence epilepsy. Ann Neurol 59(6):983-7

Mammoto A, Sasaki T, Asakura T, ,Hotta I, Imamura H, Takahashi K, Matsuura Y, Shirao T, Takai Y. (1998) Interactions of drebrin and gephyrin with profilin. Biochem Biophys Res Commun 243(1):86-9

Marco EJ, Abidi FE, Bristow J, Dean WB, Cotter P, Jeremy RJ, Schwartz CE, Sherr EH. (2008) ARHGEF9 disruption in a female patient is associated with X linked mental retardation and sensory hyperarousal. J Med Genet 45(2):100-5

Marini C, Harkin LA, Wallace RH, Mulley JC, Scheffer IE, Berkovic SF. (2003) Childhood absence epilepsy and febrile seizures: a family with a GABA(A) receptor mutation. Brain 126 (Pt 1):230-40

Miller SA, Dykes DD, Polensky HF. (1988) A simple salting out procedure for extracting DNA from human nucleated cells. Nucleic Acids Res 16(3):1215

Oefner PJ, Underhill PA. (1995) Comparative DNA sequencing by denaturing highperformance liquid chromatography (DHPLC). Am J Hum Genet 57:A266

Papadopoulos T, Eulenburg V, Reddy-Alla S, Mansuy IM, Li Y, Betz H. (2008) Collybistin is required for both the formation and maintenance of GABAergic postsynapses in the hippocampus. Mol Cell Neurosci [Epub ahead of print]

Papadopoulos T, Korte M, Eulenburg V, Kubota H, Retiounskaia M, Harvey RJ, Harvey K, O'Sullivan GA, Laube B, Hülsmann S, Geiger JR, Betz H. (2007) Impaired GABAergic transmission and altered hippocampal synaptic plasticity in collybistin-deficient mice. EMBO J 26(17):3888-99

Rees MI, Harvey K, Pearce BR, Chung SK, Duguid IC, Thomas P, Beatty S, Graham GE, Armstrong L, Shiang R, Abbott KJ, Zuberi SM, Stephenson JB, Owen MJ, Tijssen MA, van den Maagdenberg AM, Smart TG, Supplisson S, Harvey RJ. (2006) Mutations in the gene encoding GlyT2 (SLC6A5) define a presynaptic component of human startle disease. Nat Genet 38(7):801-6

Rees MI, Harvey K, Ward H, White JH, Evans L, Duguid IC, Hsu CC, Coleman SL, Miller J, Baer K, Waldvogel HJ, Gibbon F, Smart TG, Owen MJ, Harvey RJ, Snell RG. (2003) Isoform heterogeneity of the human gephyrin gene (GPHN), 
binding domains to the glycine receptor, and mutation analysis in hyperekplexia.

J Biol Chem 278(27):24688-96

Rees MI, Lewis TM, Kwok JBJ, Mortier GR, Govaert P. (2002) Hyperekplexia associated with compound heterozygote mutations in the beta-subunit of the human inhibitory glycine receptor (GLRB). Hum. Molec Genet 11: 853-860

Saiki RK, Scharf S, Falooma F, Mullis KB, Horn GT. (1985) Enzymatic amplification of B-globin sequences and restriction site analysis for diagnosis of sickle cell anemia. Science 230:1350-1354

Shiang R, Ryan SG, Zhu YZ, Hahn AF, O'Connell P, Wasmuth JJ. (1993) Mutations in the alpha 1 subunit of the inhibitory glycine receptor cause the dominant neurologic disorder, hyperekplexia. Nat Genet 5(4):351-8

Vaillend C, Poirier R, Laroche S. (2008) Genes, plasticity and mental retardation. Behav Brain Res 192(1):88-105

Wallace RH, Marini C, Petrou S, Harkin LA, Bowser DN. (2001) Mutant GABA(A) receptor gamma-2-subunit in childhood absence epilepsy and febrile seizures. Nature Genet 28:49-52

Zhou L, Chillag KL, Nigro MA. (2002) Hyperekplexia: a treatable neurogenetic disease. Brain Dev 24(7):669-74 
Tabela 1. Sequiências dos oligonucleotídeos iniciadores utilizados para amplificar os exons e as bordas exon/intron do gene ARHGEF9 e o tamanho de cada produto amplificado.

\begin{tabular}{|l|l|l|c|}
\hline & \multicolumn{1}{|c|}{ Iniciador Forward $\left(\mathbf{5}^{\prime} \rightarrow \mathbf{3}\right.$ ') } & \multicolumn{1}{|c|}{ Iniciador Reverse $\left(\mathbf{5}^{\prime} \rightarrow \mathbf{3}^{\prime}\right)$} & $\begin{array}{c}\text { Tamanho } \\
\text { do produto } \\
(\mathbf{p b})\end{array}$ \\
\hline Exon 1a-1 & ACTCGACACAATTGGGAAGC & CTCCTCCACAGCCCTACAAC & 322 \\
\hline Exon 1a-2 & TTCGCATGGAACAAACTCACT & CACAGCAAGCTCACTGGTGT & 367 \\
\hline Exon 1b & CGAGAGCCACCGAGAAAA & GCAGAGCTTGCTCCATGAAC & 300 \\
\hline Exon 2 & GAAGGGGCAAGCAAGGTA & AGGAGAACAGAGGCTGGTGA & 318 \\
\hline Exon 3 & GCCTGGAAACCTCCCAAA & AGGAGGGTTGCTGGTTCTTC & 307 \\
\hline Exon 4 & GGGACCAAAATGAGGCTCT & GACAGCTCAAACGCTCCTTC & 344 \\
\hline Exon 5 & CTTTTGGGGTCCTTGGTAGAC & GCTCAGAAAGGGCAAAAGG & 376 \\
\hline Exon 6 & CTTTAGGTGGTGTGGGTTCC & TGGGAAGCTTTTGCCAAG & 331 \\
\hline Exon 7 & TGGCCTCTTCCTATCCCAGT & ATGAAGAGGAGGGTCCGGTA & 304 \\
\hline Exon 8 & CCCCTGTGCCAACTCTTCTA & CAGAAATCTTCCCTCTGACTCC & 409 \\
\hline Exon 9 & GGCTCTCTATTCTGTGTTGTGC & ACCACCCCCAAGTAAACCTC & 410 \\
\hline Exon 10 & TGAGTTGTCTGCCCAGAGTG & GGTCTCTGTGTGTGTGTGTGTG & 455 \\
\hline
\end{tabular}

Tabela 2. Relação das temperaturas utilizadas para análise de cada amplicon do gene ARHGEF9 pela técnica de dHPLC.

\begin{tabular}{|c|c|}
\hline Exons / Amplicons & Temperaturas $\left({ }^{\circ} \mathbf{C}\right)$ \\
\hline 1A-1 & 63,5 e 64 \\
\hline 1A-2 & 63,7 e 65 \\
\hline 1B & 58 \\
\hline 2 & 59 e 61 \\
\hline 3 & 60 e 63 \\
\hline 4 & 58,7 \\
\hline 5 & $56,58,59$ e 60 \\
\hline 6 & 58,5 e 59,5 \\
\hline 7 & 61,5 e 62,5 \\
\hline 8 & 56,5 e 58,3 \\
\hline 9 & $53,7,56$ e 58 \\
\hline 10 & $52,54,58$ e 63 \\
\hline
\end{tabular}




\title{
Capítulo 5
}

\section{Colibistina e gefirina interagem com o complexo eIF3: uma nova função ligada à maquinaria de tradução protéica?}

\author{
Alencastro, $\mathrm{G}^{1}$; Sertié, $\mathrm{AL}^{1}$; Roffe, $\mathrm{M}^{2}$; Castilho, $\mathrm{BA}^{2}$; Passos-Bueno, $\mathrm{MR}^{1}$. \\ ${ }^{1}$ Centro de Estudos do Genoma Humano, Departamento de Genética e Biologia \\ Evolutiva, Instituto de Biociências, Universidade de São Paulo, SP. ${ }^{2}$ Departamento de \\ Microbiologia, Imunologia e Parasitologia, Escola Paulista de Medicina, \\ Universidade Federal de São Paulo, SP. \\ e-mail: gus_alencastro@hotmail.com \\ Palavras-chave: colibistina (gene ARHGEF9), gefirina, duplo-híbrido em levedura, \\ eIF3-p40 (eIF3S3), síntese protéica \\ Apoio financeiro: FAPESP e CNPq
}




\section{Resumo}

A proteína colibistina pertence à família das GEFs (guanine nucleotide exchange factors), as quais ativam pequenas proteínas Rho-like GTPases. Colibistina ativa especificamente a GTPase Cdc42 em fibroblastos promovendo reorganização e polarização do citoesqueleto de actina. Ainda, colibistina interage diretamente com a proteína gefirina e é responsável pela localização de gefirina e de receptores de glicina e $\mathrm{GABA}_{\mathrm{A}}$ na membrana neuronal pós-sináptica inibitória. Mutações no gene humano da colibistina (ARHGEF9) foram identificadas em três pacientes com anormalidades neurológicas e comportamentais, incluindo retardo mental, epilepsia, hiperecplexia, ansiedade e agressão. Com o objetivo de identificar outras proteínas que interagem com colibistina nós utilizamos toda a região codificadora da proteína como "isca" no sistema de duplo-híbrido em leveduras e isolamos um clone de cDNA que continha a região codificadora da proteína eIF3-p40, uma subunidade do complexo do fator 3 de iniciação de tradução protéica de eucariotos (eIF3). A associação entre colibistina e eIF3-p40 foi subseqüentemente confirmada por experimentos in vitro de coimunoprecipitação. Ainda, verificamos que a proteína gefirina também interage com eIF3-p40, e que colibistina, gefirina e eIF3-p40 podem formar um complexo em células HEK 293T. Nossos resultados sugerem que as proteínas colibistina e gefirina podem atuar no controle da tradução protéica nos sítios pós-sinápticos inibidores. 


\section{Abstract}

The collybistin protein belongs to the GEF (guanine nucleotide exchange factors) family, which activates small Rho-like GTPases. Collybistin specifically actives Cdc42 GTPase in fibroblasts, promoting the reorganization and polarization of the actin cytoskeleton. In addition, collybistin interacts directly with the gephyrin protein and is responsible for the localization of gephyrin and glycine and $\mathrm{GABA}_{\mathrm{A}}$ receptors at the inhibitory postsynaptic membrane of neurons. Mutations in the human collybistin gene (ARHGEF9) were identified in three patients with neurological and behavioral abnormalities, including mental retardation, epilepsy, hyperekplexia, anxiety and aggression. In order to identify other proteins that interact with collybistin, we used its complete protein-coding region as "bait" in the yeast twohybrid system and isolated a clone of cDNA containing the coding region of eIF3-p40 protein, a subunit of eukaryotic translation initiation factor 3 (eIF3) complex. The association between collybistin and eIF3-p40 was subsequently confirmed by in vitro co-immunoprecipitation experiments. Additionally, we found that the gephyrin protein also interacts with eIF3-p40, and that collybistin, gephyrin and eIF3-p40 can form a complex in HEK $293 \mathrm{~T}$ cells. Our results suggest that the collybistin and gephyrin proteins may act in the control of protein translation at inhibitory postsynaptic sites. 


\section{Introdução}

A proteína colibistina humana (conhecida também por hPEM-2 - proteína humana homóloga à proteína Posterior End Mark-2) é codificada pelo gene ARHGEF9, mapeado no cromossomo Xq11.2, o qual apresenta 11 exons distribuídos em aproximadamente $190 \mathrm{~Kb}$ de DNA genômico (Reid et al., 1999). A colibistina humana apresenta duas isoformas que se diferenciam apenas quanto aos primeiros resíduos de aminoácidos da região N-terminal (uma com 523 e a outra com 516 resíduos de aminoácidos). Ambas isoformas são constituídas pelos domínios DH e PH (específicos de proteínas da família GEF - guanine nucleotide exchange factors) na região central, um domínio SH3 na região N-terminal e um domínio CC na região Cterminal (estes últimos envolvidos em interações proteína-proteína) (Lemmon \& Ferguson, 2000). Análise de expressão do gene ARHGEF9 por Northern Blot revelou a presença de uma única banda em cérebro adulto e coluna espinhal e um sinal muito fraco no coração (Reid et al., 1999; Harvey et al., 2004).

A colibistina pertence à família das GEFs, proteínas que ativam pequenas Rho-like GTPases. Em fibroblastos, colibistina humana está especificamente envolvida na ativação da GTPase Cdc42, a qual tem influência na morfologia celular por induzir polimerização dos filamentos de actina e formação de protusões denominadas filopódios (Reid et al., 1999). Além de ativar a GTPase Cdc42, a proteína colibistina interage com gefirina (Kins et al., 2000), uma proteína "scaffold" que se liga a diversas proteínas do citoesqueleto e aos receptores de neurotransmissores inibidores de glicina e de GABA (compostos pelas subunidades $\alpha 2$ e $\gamma 2$ ), e é essencial para o agrupamento desses receptores nas membranas neuronais (Kneussel \& Betz, 2000). Estudos funcionais in vitro sugeriram que colibistina parece desempenhar um papel importante nas cascatas de sinalização que promovem rearranjo do citoesqueleto celular, agrupamento e recrutamento de gefirina e conseqüentemente de receptores de glicina e GABA para a membrana dos sítios pós-sinápticos inibidores (Kins et al., 2000; Harvey et al., 2004). Além da gefirina, não são conhecidas outras proteínas que interagem com colibistina e nem seu modo de regulação.

Recentemente foram descritos camundongos deficientes para o gene da colibistina. Em 2007, Papadopoulos et al. geraram camundongos nocautes 
constitutivos para colibistina, os quais apresentaram redução da transmissão gabaérgica e alteração da plasticidade sináptica em determinadas regiões do sistema nervoso central. No hipocampo desses camundongos adultos, os agrupamentos de gefirina e de receptores $\mathrm{GABA}_{\mathrm{A}}$ foram significativamente reduzidos nos sítios póssinápticos. Essas alterações ocasionaram diminuição do aprendizado espacial e do comportamento exploratório e aumento da ansiedade. Em 2008, Papadopoulos et al. geraram camundongos nos quais a colibistina foi nocauteada no prosencéfalo em diferentes estágios do desenvolvimento pós-natal. Os autores verificaram que a colibistina é necessária tanto para a localização inicial como para a manutenção de gefirina e de receptores $\mathrm{GABA}_{\mathrm{A}}$ nas membranas pós-sinápticas dos neurônicos do hipocampo. Assim, esses resultados confirmaram os estudos prévios in vitro de que a colibistina tem um papel essencial em sinaptogênese inibitória.

Em humanos, o importante papel da colibistina na formação e funcionamento das sinapses inibitórias veio com a recente identificação de três mutações patogênicas no gene ARHGEF9. Harvey et al. (2004) identificaram uma mutação de substitutição de aminoácido no domínio SH3 de colibistina em um paciente com retardo mental grave, hiperecplexia e epilepsia. Marco et al. (2008) identificaram uma inversão paracêntrica no cromossomo X que rompia o gene ARHGEF9 em uma paciente com retardo mental moderado e hiperestimulação sensorial. Kalscheuer et al. (2008) descreveram uma translocação balanceada entre o cromossomo X e o 18, na qual um dos pontos de quebra rompia parte do gene ARHGEF9, em uma paciente com retardo mental profundo, epilepsia, dismorfismo facial, ansiedade, insônia e comportamento de agressividade.

O conhecimento sobre as cascatas de sinalização responsáveis pelo agrupamento e organização de receptores sinápticos ainda é escasso. Neste trabalho utilizamos o sistema de duplo-híbrido em leveduras para procurar por proteínas que interagem com a colibistina humana, as quais podem estar envolvidas na sua regulação ou estar sob sua regulação. Descrevemos interação entre colibistina e a proteína eIF3-p40, que é uma das subunidades do complexo multiprotéico do fator 3 de iniciação de tradução em eucariotos (eIF3 - eukaryotic initiation factor 3). Além disso, observamos que a proteína gefirina também faz parte deste complexo. Nossos resultados sugerem envolvimento das proteínas colibistina e gefirina no controle da tradução protéica em sinapses inibitórias do sistema nervoso central. 


\section{Materiais e Métodos}

\section{Sistema de duplo-híbrido em leveduras}

Para identificação de proteínas que interagem com colibistina foi utilizado o sistema de duplo-híbrido em leveduras MATCHMAKER Gal4 Two-Hybrid System 3 da Clontech. Este sistema emprega duas linhagens haplóides da levedura Saccharomyces cerevisae (AH109 e Y187), as quais têm capacidade de se fundirem formando assim células diplóides.

Para obter o cDNA da proteína colibistina (GenBank: NM_015185), $5 \mu \mathrm{g}$ de RNA total extraído de cérebro fetal humano (Invitrogen) foram convertidos para cDNA com o emprego de random hexamers e da enzima transcriptase reversa SuperScript II (Invitrogen), seguindo protocolo do fabricante. Em seguida, foi utilizada a técnica de PCR (polymerase chain reaction - Saiki et al., 1985) para amplificar o cDNA da colibistina empregando oligonucleotídeos iniciadores específicos para seqüência desse gene (Tabela 1). Após a amplificação, o cDNA foi clonado no vetor pGBKT7 (do sistema de duplo-híbrido) em fase com a seqüência codificadora do domínio que se liga ao DNA do fator de transcrição Gal4 (construção pGBKT7-colibistina). Para servir como controle positivo de interação com colibistina, o cDNA da proteína gefirina (GenBank: NM_001024218) foi amplificado (conforme acima descrito para clonagem do cDNA da proteína colibistina a partir de RNA de cérebro humano fetal - seqüência dos oligonucleotídeos na Tabela 1) e clonado no vetor pGADT7 (do sistema de duplo-híbrido) em fase com a sequiência codificadora do domínio que ativa o fator de transcrição Gal4 (construção pGADT7-gefirina). Essas clonagens foram feitas de acordo com protocolos padrões de clonagem molecular (Ausubel et al., 1997). As seqüências corretas das construções foram verificadas por seqüenciamento automático, com a auxílio do aparelho MegaBACE ${ }^{T M}$ (Amersham Biosciences), e analisadas com o software BioEdit (www.mbio.ncsu.edu/BioEdit/bioedit.html).

Após as clonagens, a linhagem de levedura AH109 foi transformada com a construção pGBKT7-colibistina. Foram realizados todos os testes sugeridos pelo fabricante para verificar se a proteína colibistina sozinha não era capaz de ativar a transcrição dos genes repórteres HIS3, ADE2, $\alpha$-galactosidase e $\beta$-galactosidase utilizados no sistema de duplo-híbrido em levedura. Uma vez realizados esses testes 
(os quais forneceram os resultados esperados, isto é, colibistina sozinha não era capaz de ativar a transcrição dos genes repórteres), a construção pGBKT7-colibistina foi utilizada como "isca" na triagem de uma biblioteca de cérebro humano fetal (Pretransformed Human Fetal Brain MATCHMAKER cDNA Library-Clontech), que já vem clonada no vetor pGADT7 e transformada na linhagem Y187 de levedura.

Após o acoplamento entre a levedura AH109 (transformada com o plasmídeo "isca" pGBKT7-colibistina) e a levedura Y187 (transformada com a biblioteca de cDNA de cérebro humano fetal clonada no vetor pGADT7), os clones positivos foram selecionados pelo crescimento em meio de cultura seletivo, como descrito no manual do sistema.

As interações entre colibistina e as proteínas-candidatas identificadas na triagem inicial da biblioteca de cDNA de cérebro humano fetal foram posteriormente confirmadas em levedura pela transformação de células AH109 com o plasmídeo pGBKT7-colibistina juntamente com cada um dos plasmídeos pGADT7 contendo toda ou parte da região codificadora das proteínas candidatas a interagir com colibistina (denominados plasmídeos presas) (Tabela 2). Esses plasmídeos presas foram isolados a partir das próprias colônias de levedura que cresceram nos meios seletivos, de acordo com o protocolo sugerido pelo fabricante.

\section{Preparação das proteínas recombinantes para ensaios de co-imunoprecipitação}

Foram utilizados dois vetores de expressão em células de mamíferos: pExchange4 (Stratagene) e pcDNA3 (Invitrogen), os quais contêm na região Nterminal o epítopo c-myc e flag, respectivamente. Os cDNAs de toda a região codificadora das proteínas eIF3-p40 (GenBank: HSU54559), colibistina e gefirina foram amplificados dos vetores utilizados no sistema de duplo-híbrido em levedura. As sequiências dos oligonucleotídeos iniciadores específicos utilizados para essas amplificações estão descritas na Tabela 3. Com a utilização de protocolos padrões de clonagem molecular, foram clonados: o cDNA da proteínas eIF3-p40 no vetor pExchange4 (construção pExchange4-eIF3-p40, que produz a proteína recombinante cmyc-eIF3-p40); o cDNA da proteína colibistina nos vetores pcDNA3 (construção pcDNA3-colibistina, que produz a proteína recombinante flag-colibistina) e pExchange4 (construção pExchange4-colibistina, que produz a proteína recombinante cmyc-colibistina); o cDNA da proteína gefirina no vetor pcDNA3 (construção 
pcDNA3-gefirina, que produz a proteína recombinante flag-gefirina). A seqüência correta de todas as construções foi verificada por seqüenciamento automático, com auxílio do aparelho MegaBACE ${ }^{T M}$, e analisadas com o software BioEdit.

\section{Cultura de células HEK 293T, transfecção das células e análise da expressão das proteínas recombinantes por Western blotting}

Células HEK 293T (human embryonic kidney 293T) foram cultivadas no meio DMEM High-glicose (Invitrogen), suplementadas com 10\% de soro fetal bovino (Gibco), $1 \%$ de estreptomicina/ampicilina (Sigma-Aldrich), mantidas a $37^{\circ} \mathrm{C}$ e $5 \%$ de $\mathrm{CO}_{2}$ até atingirem confluência antes de serem utilizadas nos experimentos ou de serem replicadas.

As células HEK 293T foram transfectadas com as construções acima descritas utilizando o kit e o protocolo do reagente Lipofectamina 2000 (Invitrogen). Para as transfecções duplas (dois vetores) foram utilizados $2 \mu \mathrm{g}$ de cada plasmídeo e para as transfecções triplas (três vetores) 1,3 $\mu$ g de cada plasmídeo.

Para confirmar a expressão das proteínas recombinantes nas células HEK 293T, 48 horas após as transfecções, as células foram lavadas com PBS 1X gelado, lisadas em $500 \mu \mathrm{l}$ de tampão RIPA (50mM de Tris-HCL, pH 7,4; 150mM NaCl; 1mM EDTA, $1 \%$ (v/v) Nonidet-40; $0.1 \%$ (w/v) SDS; 0.5\% (w/v) DOC; tablete de inibidores de proteases), centrifugadas a $14.000 \mathrm{RPM}$ por 15 minutos a $4^{\circ} \mathrm{C}$ e o sobrenadante transferido para um novo tubo. As proteínas do sobrenadante $(25 \mu \mathrm{g})$ foram misturadas com $2 \mathrm{X}$ protein loading buffer e separadas em gel de SDSpoliacrilamida $10 \%$. Após a transferência das proteínas do gel para membranas de nitrocelulose (Hybond ${ }^{T M}-C$ Extra - GE Healthcare), estas foram incubadas com os anticorpos primários monoclonais anti-cmyc (Clontech) ou anti-flag (Sigma) (ambos produzidos em camundongos). Utilizamos o anticorpo secundário anti-camundongo (produzido em cabra) conjugado à enzima peroxidase (Santa Cruz Biotechnology). Proteínas imunorreativas foram então detectadas com o reagente $E C L^{T M}$ Western Blotting Analysis System (Amersham Biosciences), seguindo o protocolo do fabricante. 


\section{Ensaios de co-imunoprecipitação das proteínas recombinantes super-expressas em células HEK 293T}

Inicialmente, as células HEK 293T foram transfectadas com as combinações dos vetores esquematizados na Tabela 4. As células transfectadas foram lisadas em tampão RIPA, e o lisado foi centrifugado a 14.000 RPM por 15 minutos a $4^{\circ} \mathrm{C}$. O sobrenadante (aproximadamente $15 \mu \mathrm{g}$ ) foi imunoprecipitado com $5 \mu \mathrm{g}$ do anticorpo anti-flag overnight sob leve agitação a $4^{\circ} \mathrm{C}$. Após esse período, foi adicionado cerca de $50 \mu 1$ de beads de agarose (Protein G Sepharose ${ }^{\mathrm{TM}}$ - do kit Immunoprecipitation Starter Pack - GE Healthcare) aos lisados que foram então incubados por mais 3-4 horas sob leve agitação a $4^{\circ} \mathrm{C}$. Os imunoprecipitados foram separados por breve centrifugação e lavados 3x em tampão RIPA e 1x em tampão Tris 50mM pH 8,0. As amostras foram ressuspendidas em $30 \mu 1$ de $2 \mathrm{X}$ protein loading buffer, fervidas por 5 minutos e aplicadas em géis de SDS-poliacrilamida $10 \%$. Após a transferência das proteínas para as membranas de nitrocelulose, estas foram expostas ao anticorpo primário anti-cmyc. Utilizamos o anticorpo secundário anti-camundongo (produzido em cabra) conjugado à enzima peroxidase, e as proteínas imunorreativas foram então detectadas com o reagente ECL ${ }^{T M}$ Western Blotting Analysis System.

\section{Preparação de extratos de proteínas totais de cérebros de camundongos congelados para experimentos de co-imunoprecipitação in vivo com proteínas endógenas}

Para verificar a expressão das proteínas de interesse (incluindo colibistina, gefirina, eIF3-p40 e eIF3-p116) em cérebro de camundongos adultos, cérebros congelados foram macerados até que se tornassem pó e misturados ao tampão RIPA (500 $\mu 1$ de RIPA para cada $100 \mathrm{mg}$ de tecido macerado). Em seguida, cada um dos lisados foi passado 10x por uma agulha de calibre $21 \mathrm{G}$, incubado no gelo por 30 minutos e centrifugados a $14.000 \mathrm{RPM}$ por 30 minutos a $4^{\circ} \mathrm{C}$. A expressão das proteínas endógenas de interesse foi verificada com a utilização de aproximadamente $200 \mu \mathrm{g}$ do lisado de proteínas totais dos cérebros de camundongos, os quais foram misturados com $2 \mathrm{X}$ protein loading buffer, fervidos por 5 minutos e então aplicados em géis de SDS-poliacrilamida 10\%. Após a transferência, as membranas foram expostas aos anticorpos primários anti-colibistina (produzido em camundongo; $B D$ 
Biosciences), anti-eIF3-p40 (produzido em cabra; Santa Cruz Biotechnology), antigefirina (produzido em cabra; Santa Cruz Biotechnology), e anti-eIF3-p116 (N-20) (produzido em cabra; Santa Cruz Biotechnology). Utilizamos o anticorpo secundário anti-cabra (produzido em burro) para detectar os anticorpos primários produzidos em cabra, e anti-camundongo (produzido em cabra) para detectar o anticorpo primário produzido em camundongo. Ambos os anticorpos secundários estão conjugados à enzima peroxidase (Santa Cruz Biotechnology). As proteínas imunorreativas foram então detectadas com o reagente $E C L^{T M}$ Western Blotting Analysis System.

\section{Ensaios de co-imunoprecipitação das proteínas endógenas expressas em cérebro de camundongo}

Como os anticorpos primários disponíveis para as proteínas colibistina, gefirina e eIF3-p40 não funcionam para imunoprecipitação (informações dos fabricantes), nesse experimento optamos por utilizar um anticorpo contra a proteína eIF3-p116 (também constituinte do complexo eIF3), pois havia sido descrito anteriormente na literatura científica que esse anticorpo funcionava bem em experimentos de co-imunoprecipitação para imunoprecipitar eIF3-p116 e juntamente com ela eIF3-p40 (Ogawa et al., 2005). Sendo assim, utilizamos o anticorpo antieIF3-p116 (N-20) para co-imunoprecipitar a proteína eIF3-p40 e, com ela, as proteínas colibistina e gefirina.

As co-imunoprecipitações, esquematizadas na Tabela 5, foram realizadas utilizando o kit Immunoprecipitation Starter Pack. Aproximadamente $10 \mathrm{mg}$ do lisado de proteínas totais de cérebros de camundongos adultos foram imunoprecipitados com $5 \mu \mathrm{g}$ do anticorpo anti-eIF3-p116 (N-20) overnight sob leve agitação a $4^{\circ} \mathrm{C}$. Após esse período, foram adicionados cerca de $50 \mu \mathrm{l}$ de beads de agarose (Protein G Sepharose ${ }^{\mathrm{TM}}$ ) aos lisados que foram então incubados por mais 3-4 horas sob leve agitação a $4^{\circ} \mathrm{C}$. Os imunoprecipitados foram separados por breve centrifugação e lavados 3x em tampão RIPA e 1x em tampão Tris 50mM pH 8,0. As amostras foram ressuspendidas em $30 \mu 1$ de $2 \mathrm{X}$ protein loading buffer, fervidas por 5 minutos e aplicadas em géis de SDS-poliacrilamida $10 \%$. Após a transferência das proteínas do gel para membranas de nitrocelulose, estas foram expostas aos anticorpos primários anti-colibistina, anti-gefirina, anti-eIF3-p40 ou anti-eIF3-p116. Utilizamos o anticorpo secundário anti-cabra (produzido em burro) para detectar os 
anticorpos primários produzidos em cabra, e anti-camundongo (produzido em cabra) para detectar o anticorpo primário produzido em camundongo. Ambos os anticorpos secundários estão conjugados à enzima peroxidase. As proteínas imunorreativas foram então detectadas com o reagente $E C L^{T M}$ Western Blotting Analysis System.

\section{Resultados}

\section{Identificação de proteínas candidatas a interagir com colibistina}

Com o objetivo de identificar novas proteínas que interagem com colibistina, nós utilizamos o sistema de duplo-híbrido em leveduras e triamos uma biblioteca de cDNAs de cérebro humano fetal. Nós analisamos aproximadamente $1,08 \times 10^{6}$ colônias transformantes e obtivemos 8 clones positivos diferentes (isto é, clones expressando proteínas candidatas a interagir com colibistina que cresceram nos meios seletivos utilizados no sistema de duplo-híbrido) (Tabela 6). Para confirmar a interação entre colibistina e essas 8 proteínas candidatas em levedura (pelo sistema de duplo-híbrido), os vetores contendo os cDNAs dessas proteínas foram isolados e transfectados novamente em levedura, um a um, juntamente com o vetor expressando a proteína colibistina (pGBKT7-colibistina) (Tabela 2). Após esse teste, conseguimos confirmar a interação da colibistina com as proteínas eIF3-p40 (translation initiation factor eIF3 p40 subunit), SFRS14 (splicing factor - arginine/serine-rich 14) e WBP5 (WW domain binding protein 5) em leveduras (Figura 1). Essas interações parecem ser específicas, uma vez que a construção pGBKT7-colibistina não foi capaz sozinha de ativar a transcrição dos genes repórteres das leveduras.

A proteína eIF3-p40 faz parte de um complexo multiprotéico composto por pelo menos 12 proteínas que constituem o fator eIF3 de início da tradução protéica em eucariotos. A proteína SFRS14 apresenta homologia com proteínas da família SURP que controlam o processamento (splicing) de RNAs. Contudo, a função da proteína SFRS14 ainda não é conhecida. A proteína WBP5 apresenta o domínio WW de ligação protéica. Este domínio globular WW é compartilhado por proteínas de diversas funções incluindo proteínas estruturais, regulatórias e de sinalização, contudo ainda não se conhece as funções da proteína WBP5. 


\section{Análise da interação entre colibistina e a proteína eIF3-p40 em células HEK 293 por co-imunoprecipitação}

Para confirmar que a proteína colibistina interage com as proteínas candidatas eIF3-p40, SFRS14 e WBP5 isoladas com a utilização do sistema de duplo-híbrido em leveduras, optamos por realizar inicialmente experimentos de co-imunoprecipitação in vitro. Infelizmente não conseguimos clonar os cDNAs das proteínas SFRS14 e WBP5 em vetores de expressão de células de mamíferos. Assim, analisamos apenas a interação da proteína colibistina com a eIF3-p40 por co-imunoprecipitação. Conforme discutido abaixo, também analisamos a interação de gefirina com eIF3-p40 (Tabela 4).

\section{Co-imunoprecipitações duplas}

Quando as proteínas recombinantes flag-colibistina e cmyc-eIF3-p40 foram super-expressas em células HEK 293T, e os lisados de proteínas totais dessas células foram incubados com o anticorpo anti-flag e submetidos ao protocolo de imunoprecipitação, observamos que cmyc-eIF3-p40 co-imunoprecipitou com flagcolibistina (Figura 2). Esses resultados confirmaram a interação encontrada inicialmente em levedura.

Para verificar se a proteína gefirina também era capaz de interagir com eIF3p40, as proteínas recombinantes flag-gefirina e cmyc-eIF3-p40 foram super-expressas em células HEK 293T. Quando os lisados de proteínas totais dessas células foram incubados com o anticorpo anti-flag e submetidos ao protocolo de imunoprecipitação, verificamos que cmyc-eIF3-p40 co-imunoprecipitou com flag-gefirina (Figura 3). Esses resultados sugerem que eIF3-p40 e gefirina também interagem em células HEK $293 T$.

\section{Co-imunoprecipitações triplas}

Para verificar se as proteínas gefirina, colibistina e eIF3-p40 eram capazes de formar um complexo, as proteínas recombinantes cmyc-colibistina, cmyc-eIF3-p40 e flag-gefirina foram super-expressas em células HEK 293T. Quando os lisados de proteínas totais dessas células foram incubados com o anticorpo anti-flag e submetidos ao protocolo de imunoprecipitação, verificamos que cmyc-colibistina e cmyc-eIF3-p40 co-imunoprecipitam com flag-gefirina (Figura 4). Esses resultados 
sugerem que eIF3-p40, colibistina e gefirina formam um complexo protéico em células HEK 293T.

\section{Análise da interação entre colibistina e a proteína eIF3-p40 em cérebro de camundongo}

Para verificar se as proteínas colibistina e eIF3-p40, assim como as proteínas gefirina e eIF3-p40, são realmente capazes de interagir in vivo, realizamos experimentos de co-imunoprecipitação utilizando lisados de cérebros de camundongos adultos.

Inicialmente verificamos, por Western blot, que cérebro de camundongo adulto expressa as proteínas eIF3-p40, eIF3-p116, colibistina e gefirina (dados não apresentados). Conforme discutido no item Materiais e Métodos, como os anticorpos que dispúnhamos contra as proteínas eIF3-p40, colibistina e gefirina não funcionavam em experimentos de imunoprecipitação, optamos por utilizar o anticorpo contra a proteína eIF3-p116, que também faz parte do complexo de iniciação da tradução eIF3.

Os experimentos de co-imunoprecipitação das proteínas endógenas expressas em cérebro de camundongo adulto (Tabela 5) sugerem que as proteínas colibistina e gefirina aparentemente co-imunoprecipitam com a proteína eIF3-p116 (Figura 5). Assim, esses resultados sugerem que as proteínas colibistina, eIF3-p116, eIF3-p40 e gefirina interagem in vivo. Contudo, enfrentamos algumas dificuldades técnicas com esses experimentos, os quais precisam ser repetidos com a utilização de controles negativos apropriados, os quais não foram utilizados nos experimentos mostrados (Figura 5).

\section{Discussão}

Neste trabalho nós descrevemos a interação entre as proteínas colibistina e gefirina e a proteína eIF3-p40, uma das subunidades do complexo multiprotéico eIF3 de início da tradução de eucariotos. Não sabemos se a interação entre colibistina e eIF3-p40 é direta ou depende da interação com outras proteínas, como a proteína gefirina. Gefirina é expressa em diversos tipos celulares, inclusive em células HEK $293 \mathrm{~T}$ (dados não apresentados). Assim, nos experimentos de co-imunoprecipitação 
onde super-expressamos as proteínas colibistina e eIF3-p40 nas células HEK 293T, pode ser que a interação vista entre essas duas proteínas seja mediada pela gefirina expressa endogenamente nas células. Por outro lado, podemos afirmar que a interação entre gefirina e eIF3-p40 vista em células HEK 293T parece não ser mediada por colibistina, uma vez que essas células não expressam colibistina (dados não apresentados). Aparentemente também confirmamos a interação de colibistina e gefirina com eIF3-p40 em cérebro de camundongo adulto, apesar de não termos fotos muito boas dos raio-X das membranas de Western blot e de esses experimentos deverem ser repetidos com o uso de controles negativos apropriados.

As interações identificadas neste trabalho, sendo diretas ou indiretas, parecem ligar as proteínas colibistina e gefirina ao complexo de início de tradução eIF3. É sabido que as sinapses possuem sua própria síntese protéica (Smith et al., 2001). Essa síntese proporciona um mecanismo eficiente para a disponibilização rápida de proteínas nas sinapses, que é importante para os eventos de plasticidade sináptica e de memória de longo prazo (revisado em Klann et al., 2004; Schuman et al., 2006 e Zhong et al., 2006). Assim, os resultados obtidos neste trabalho sugerem que as proteínas colibistina e gefirina possam estar envolvidas no controle da tradução nas sinapses.

$\mathrm{O}$ inicio da tradução protéica em eucariotos compreende diversas etapas. $\mathrm{Na}$ fase inicial o fator de iniciação eIF4E se liga à porção CAP $\left(5^{\prime} \mathrm{m}^{7} \mathrm{GpppN}\right)$ do RNAm e permite a montagem de um grande complexo de fatores de iniciação (incluindo eIF4G, eIF4A, eIF4B), ao qual se liga o complexo de pré-iniciação 43S, formado por eIF3, eIF2-GTP-Met-tRNAi e a subunidade ribossomal 40S. Uma vez montada, esta estrutura é capaz de progredir pela região 5' UTR até encontrar o códon de início da tradução protéica AUG, onde a subunidade ribossomal 60S se une ao complexo descrito, iniciando a formação de ligações peptídicas (Klann et al., 2004). O eIF3 é o maior e um dos mais complexos fatores de iniciação de tradução em eucariotos, cuja função é de se ligar ao complexo 43S inibindo a ligação prematura da subunidade ribossomal 60S e aumentar a força de ligação do complexo 43S à região 5' do RNAm (Harris et al., 2006) (Figura 6).

O processo de tradução pode ser regulado em diferentes etapas. A proteína 4EBP1 regula a tradução por meio de sua ligação com o fator de iniciação eIF4E. Quando 4E-BP1 está desfosforilada, ela se liga fortemente a eIF4E, e essa ligação 
inibi a tradução por bloquear a ligação de eIF4G à eIF4E (Harris \& Lawrence, 2003). Muitas proteínas quinases são responsáveis por fosforilar 4E-BP1, que quando fosforilada desfaz a ligação com eIF4E e a tradução é estimulada (Beretta et al., 1996). A proteína alvo da rapamicina em mamíferos - mTOR (mammalian target of rapamycin) possui uma função central nesse processo de fosforilação de 4E-BP1, bem como na fosforilação e ativação de SK61, uma quinase envolvida na regulação da tradução de um grupo específico de RNAm que contêm uma região 5' TOP (5' terminal oligopyrimidine - RNAm 5' TOP são caracterizados por conter em sua região 5 ' terminal uma seqüência de 6-12 oligopirimidinas, e são responsáveis por codificar proteínas ribossomais e proteínas que fazem parte da maquinaria de tradução - Klann et al., 2004; Iadevaia et al., 2008) (Figura 6).

É interessante ressaltar que já foi descrita interação entre a proteína gefirina e a proteína mTOR. Proteínas mTOR mutantes incapazes de interagir com gefirina são também incapazes de estimular a tradução, pois perdem a habilidade de fosforilar 4EBP1 e SK61 (Sabatini et al., 1999). Ainda, uma outra proteína constituinte do complexo eIF3, a eIF3-p47, interage com a proteína mTOR (Harris et al., 2006). Não sabemos qual a ligação funcional entre colibistina, gefirina, o complexo eIF3 e a proteína mTOR. É importante comentar ainda que mTOR é ativada pela GTPase Rheb, que em seu estado ligada ao GTP (GTP-Rheb) é capaz de ativar mTOR (Long et al., 2005). Ainda não se conhece a proteína capaz de ativar a GTPase Rheb. Assim, pode ser que colibistina tenha ação de GEF sobre Rheb e esteja, desta forma, envolvida na ativação da cascata de sinalização de mTOR (Figura 6).

É possível também que colibistina e/ou gefirina possam conectar o aparato de tradução ao citoesqueleto dos sítios pós-sinápticos, uma vez que essas proteínas participam na organização do citoesqueleto. Foi demonstrado que alguns RNAm e polissomos estão associados ao citoesqueleto e que essa associação pode influenciar no transporte, ancoragem e tradução de RNAm específicos (Hesketh, 1994; Bassel \& Singer, 1997). A associação desses RNAm com o citoesqueleto ocorre em diferentes regiões das células por meio de domínios localizados na região 3' UTR desses RNAm. É interessante também comentar que Hou et al. (2000) descreveram interação entre uma proteína do citoesqueleto, a proteína eritróide 4.1 (participa da organização do citoesqueleto em globulos vermelhos), e a subunidade eIF3-p44 do complexo eIF3. 
Em conclusão, nossos resultados sugerem que as proteínas colibistina e gefirina podem estar envolvidas no controle da tradução de RNAm. Esses resultados, uma vez comprovados funcionalmente, seriam extremamente interessante pois ajudariam na compreensão e entendimento da relação entre elementos organizadores do citoesqueleto ou proteínas com atividade GEF e fatores de iniciação de tradução em sinapses.

\section{Agradecimentos}

Gostaríamos de agradecer a Constância G. Urbani pela assistência secretarial, Marta Canovas pelas contribuições técnicas, Profa. Dra. Beatriz Castilho e seu aluno de Doutorado Martin Roffe pelas discussões pertinentes e auxílio com experimentos, Profa. Dra. Bettina Malnic pelos vetores pcDNA3 e pExchange4 e beads de agarose, Profa. Dra. Luciana Haddad pelo vetor pcDNA3 e discussões pertinentes, e a Profa. Dra. Mari Sogayar e seu aluno Dr. Fernando Lojudice pelas células HEK 293 T e auxílio com experimentos. Este trabalho foi financiado por bolsas da Fundação de Amparo à Pesquisa do Estado de São Paulo (FAPESP) e do Conselho Nacional de Desenvolvimento Científico e Tecnológico (CNPq). 


\section{Referências Bibliográficas}

Ausubel FM, Brent R, Kingston RE, Moore DD, Seidman JG. (1997) Current Protocols in Molecular Biology.

Bassell G, Singer RH. (1997) mRNA and cytoskeletal filaments. Curr Opin Cell Biol 9(1):109-15

Harris TE, Chi A, Shabanowitz J, Hunt DF, Rhoads RE, Lawrence JC Jr. (2006) mTOR-dependent stimulation of the association of eIF4G and eIF3 by insulin. EMBO J 25(8):1659-68

Harris TE, Lawrence JC Jr. (2003) TOR signaling. Sci STKE (212):re15

Hou CL, Tang C, Roffler SR, Tang TK. (2000) Protein 4.1R binding to eIF3-p44 suggests an interaction between the cytoskeletal network and the translation apparatus. Blood 96(2):747-53

Harvey K, Duguid IC, Alldred MJ, Beatty SE, Ward H, Keep NH, Lingenfelter SE, Pearce BR, Lundgren J, Owen MJ, Smart TG, Luscher B, Rees MI, Harvey RJ. (2004) The GDP-GTP exchange factor collybistin: an essential determinant of neuronal gephyrin clustering. J Neurosci 24(25):5816-26

Hesketh J. (1994) Translation and the cytoskeleton: a mechanism for targeted protein synthesis. Mol Biol Rep 19(3):233-43

Iadevaia V, Caldarola S, Tino E, Amaldi F, Loreni F. (2008) All translation elongation factors and the $\mathrm{e}, \mathrm{f}$, and $\mathrm{h}$ subunits of translation initiation factor 3 are encoded by 5'-terminal oligopyrimidine (TOP) mRNAs. RNA [Epub ahead of print]

Kalscheuer VM, Musante L, Fang C, Hoffmann K, Fuchs C, Carta E, Deas E, Venkateswarlu K, Menzel C, Ullmann R, Tommerup N, Dalprà L, Tzschach A, Selicorni A, Lüscher B, Ropers HH, Harvey K, Harvey RJ. (2008) A balanced chromosomal translocation disrupting ARHGEF9 is associated with epilepsy, anxiety, aggression, and mental retardation. Hum Mutat [Epub ahead of print]

Kins S, Betz H, Kirsch J. (2000) Collybistin, a newly identified brain-specific GEF, induces submembrane clustering of gephyrin. Nat Neurosci 3(1):22-9

Klann E, Antion MD, Banko JL, Hou L. (2004) Synaptic plasticity and translation initiation. Learn Mem 11(4):365-72

Kneussel M, Betz H. (2000) Receptors, gephyrin and gephyrin-associated proteins: novel insights into the assembly of inhibitory postsynaptic membrane specializations. J Physiol 525 (Pt 1):1-9 
Lemmon MA, Ferguson KM. (2000) Signal-dependent membrane targeting by pleckstrin homology (PH) domains. Biochem J 350 (Pt 1): 1-18

Long X, Lin Y, Ortiz-Vega S, Yonezawa K, Avruch J. (2005) Rheb binds and regulates the mTOR kinase. Curr Biol 15(8):702-13

Marco EJ, Abidi FE, Bristow J, Dean WB, Cotter P, Jeremy RJ, Schwartz CE, Sherr EH. (2008) ARHGEF9 disruption in a female patient is associated with X linked mental retardation and sensory hyperarousal. J Med Genet 45(2):100-5

Ogawa F, Kasai M, Akiyama T. (2005) A functional link between Disrupted- In Schizophrenia 1 and the eukaryotic translation initiation factor 3. Biochem Biophys Res Commun 338(2):771-6. Erratum in: Biochem Biophys Res Commun. 2006; 345(3):1273.

Papadopoulos T, Korte M, Eulenburg V, Kubota H, Retiounskaia M, Harvey RJ, Harvey K, O'Sullivan GA, Laube B, Hülsmann S, Geiger JR, Betz H. (2007) Impaired GABAergic transmission and altered hippocampal synaptic plasticity in collybistin-deficient mice. EMBO J 26(17):3888-99

Papadopoulos T, Eulenburg V, Reddy-Alla S, Mansuy IM, Li Y, Betz H. (2008) Collybistin is required for both the formation and maintenance of GABAergic postsynapses in the hippocampus. Mol Cell Neurosci [Epub ahead of print]

Reid T, Bathoorn A, Ahmadian MR, Collard JG. (1999) Identification and characterization of hPEM-2, a guanine nucleotide exchange factor specific for Cdc42. J Biol Chem 274(47):33587-93

Sabatini DM, Barrow RK, Blackshaw S, Burnett PE, Lai MM, Field ME, Bahr BA, Kirsch J, Betz H, Snyder SH. (1999) Interaction of RAFT1 with gephyrin required for rapamycin-sensitive signaling. Science 284(5417):1161-4

Saiki RK, Scharf S, Falooma F, Mullis KB, Horn GT. (1985) Enzymatic amplification of B-globin sequences and restriction site analysis for diagnosis of sickle cell anemia. Science 230:1350-1354

Schuman EM, Dynes JL, Steward O. (2006) Synaptic regulation of translation of dendritic mRNAs. J Neurosci 26(27):7143-6

Smith WB, Aakalu G, Schuman EM. (2001) Local protein synthesis in neurons. Curr Biol 11(22):R901-3

Zhong J, Zhang T, Bloch LM. (2006) Dendritic mRNAs encode diversified functionalities in hippocampal pyramidal neurons. BMC Neurosci 7:17 


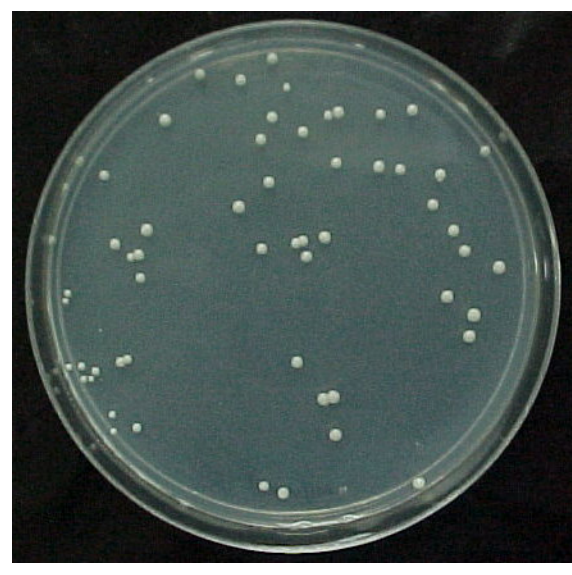

Meio SD/-Trp/-Leu/-His/-Ade

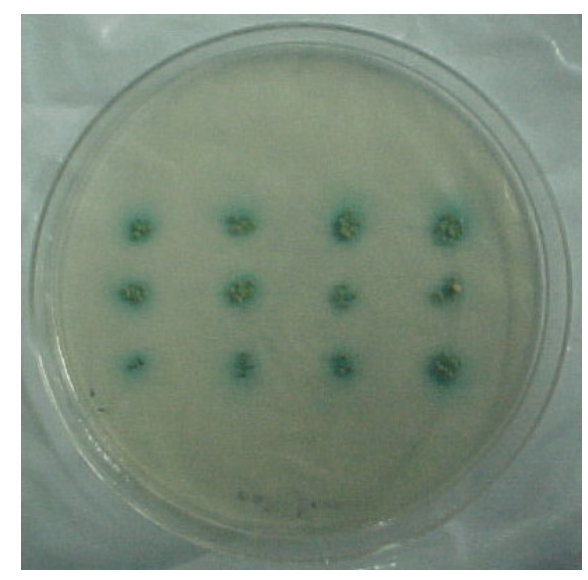

Meio SD/-Trp/-Leu/-His/-Ade/ X- $\alpha-G a l$

Figura 1. Fotografias mostrando o crescimento das colônias de levedura AH109 expressando as proteínas de interesse nos meios de culturas seletivos para verificar interação entre essas proteínas.

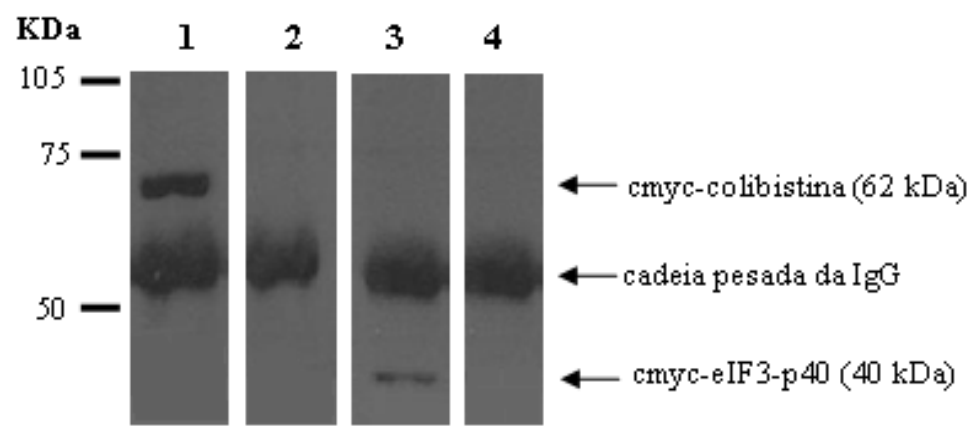

Figura 2. Raio-X da membrana de Western blot marcada com o anticorpo anti-cmyc.

Os experimentos de imunoprecipitação foram realizados com o anticorpo anti-flag e os de Western blot com o anticorpo anti-cmyc. KDa: Marcador de peso molecular (Rainbow $^{T M}$ - Amershan Life Sciense). (1) pExchange4-colibistina + pcDNA3gefirina (controle positivo). (2) pExchange4-colibistina + pcDNA3- $\phi$ (controle negativo). (3) pExchange4-eIF3-p40 + pcDNA3-colibistina (teste de interação). (4) pExchange4-eIF3-p40 + pcDNA3- $\phi$ (controle negativo). Conforme o esperado, observamos co-imunoprecipitação de cmyc-colibistina com flag-gefirina (experimento 1), mas não observamos co-imunoprecipitação de cmyc-colibistina com flag- $\phi$ e cmyc-eIF3-p40 com flag- $\phi$ (experimentos 2 e 4). Ainda, observamos coimunoprecipitação de cmyc-eIF3-p40 com flag-colibistina (experimento 3). Esses resultados confirmam a interação entre colibistina e eIF3-p40 em células HEK 293T. 


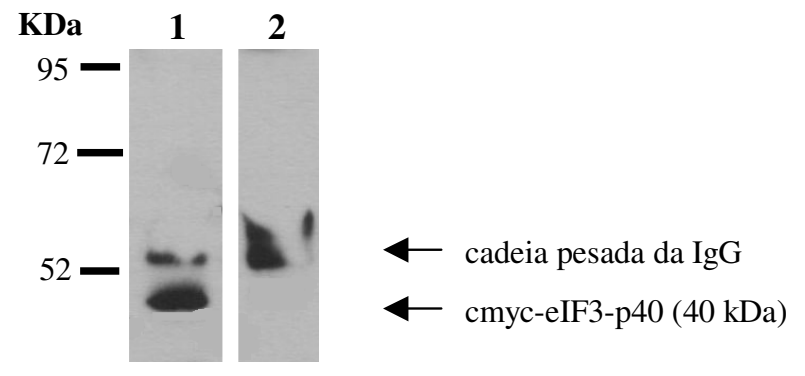

Figura 3. Raio X da membrana de Western blot marcada com o anticorpo anti-cmyc.

Os experimentos de imunoprecipitação foram realizados com o anticorpo anti-flag e os de Western blot com o anticorpo anti-cmyc. (KDa) Marcador de peso molecular (Spectra ${ }^{T M}$ - Fermentas). (1) pExchange4-eIF3-p40 + pcDNA3-gefirina (teste de interação). (2) pExchange4- $\phi+$ pcDNA3-gefirina (controle negativo). Conforme o esperado, não observamos co-imunoprecipitação de cmyc- $\phi$ com flag-gefirina (experimento 2). Por outro lado, observamos co-imunoprecipitação de cmyc-eIF3-p40 com flag-gefirina (experimento 1). Esses resultados sugerem a interação entre gefirina e eIF3-p40 em células HEK 293T.

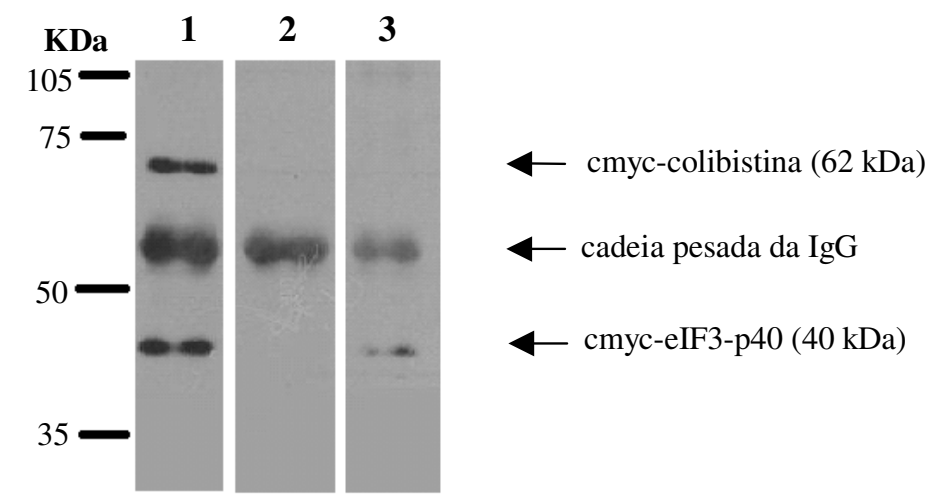

Figura 4. Raio X da membrana de Western blot marcada com o anticorpo anti-c-myc.

Os experimentos de imunoprecipitação foram realizados com o anticorpo anti-flag e os de Western blot com o anticorpo anti-cmyc. (KDa) Marcador de peso molecular (Rainbow $^{T M}$ - Amershan Life Sciense). (1) pExchange4-eIF3-p40 + pExchange4colibistina + pcDNA3-gefirina (teste de interação). (2) pExchange4-eIF3-p40 + pExchange4-colibistina + pcDNA3- $\phi$ (controle negativo). (3) pExchange-eIF3-p40 + pcDNA3-colibistina (controle positivo). Conforme o esperado, observamos coimunoprecipitação de cmyc-eIF3-p40 com flag-colibistina (experimento 3), mas não observamos co-imunoprecipitação de cmyc-eIF3-p40 e cmyc-colibistina com flag- $\phi$ (experimento 2). Ainda, observamos co-imunoprecipitação de cmyc-eIF3-p40 e cmyccolibistina com flag-gefirina (experimento 1). Esses resultados sugerem que as proteínas colibistina, gefirina e eIF3-p40 formam um complexo em células HEK 293T. 
(A)

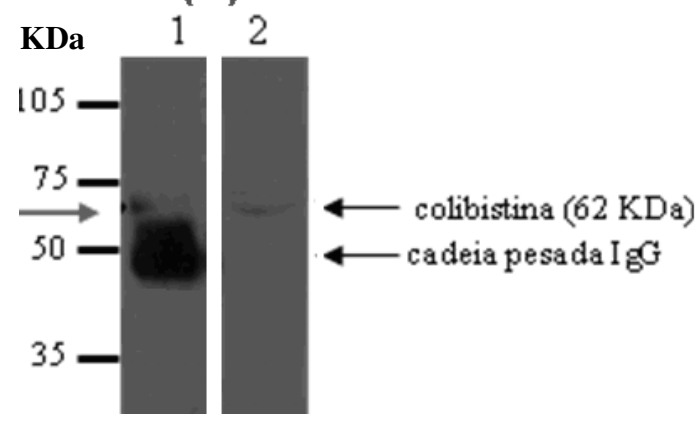

(B)

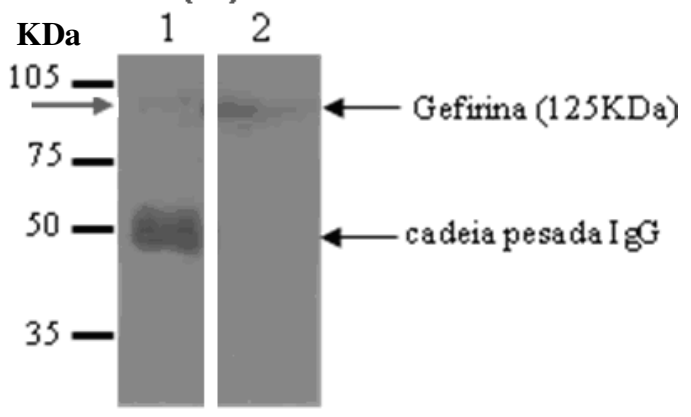

Figura 5. Raios-X das membranas de Western blot marcadas com os anticorpos anticolibistina (A) e anti-gefirina (B).

(KDa) Marcador de peso molecular (Rainbow ${ }^{T M}$ - Amershan Life Sciense).

(A)Experimento 1: Este experimento de imunoprecipitação foi realizado com o anticorpo anti-eIF3-p116 e o de Western blot com o anticorpo anti-colibistina. Experimento 2: Lisado de proteínas totais $(\sim 200 \mu \mathrm{g})$ de cérebro de camundongo utilizado no experimento de imunoprecipitação.

Embora a banda referente a proteína colibistina esteja muito fraca (experimento 1), observamos co-imunoprecipitação de colibistina com eIF3-p116, sugerindo interação de colibistina ao complexo eIF3 em cérebro de camundongo. Contudo, esses experimentos precisam ser repetidos com a utilização de controles negativos apropriados.

(B)Experimento 1: Este experimento de imunoprecipitação foi realizado com o anticorpo anti-eIF3-p116 e o de Western blot com o anticorpo anti-gefirina. Experimento 2: Lisado de proteínas totais $(\sim 200 \mu \mathrm{g})$ de cérebro de camundongo utilizado no experimento de imunoprecipitação.

Observamos co-imunoprecipitação de gefirina com eIF3-p116, sugerindo interação de gefirina ao complexo eIF3 em cérebro de camundongo. Contudo, esses experimentos precisam ser repetidos com a utilização de controles negativos apropriados.

Embora não apresentado neste trabalho, também expusemos as membranas acima aos anticorpos primários anti-eIF3-p40 e anti-eIF3-p116 para checar a eficiência das imunoprecipitações. Os resultados obtidos revelaram que utilizando o anticorpo antieIF3-p116 conseguimos imunoprecipitar a própria proteína eIF3-p116 e com ela a proteína eIF3-p40. 


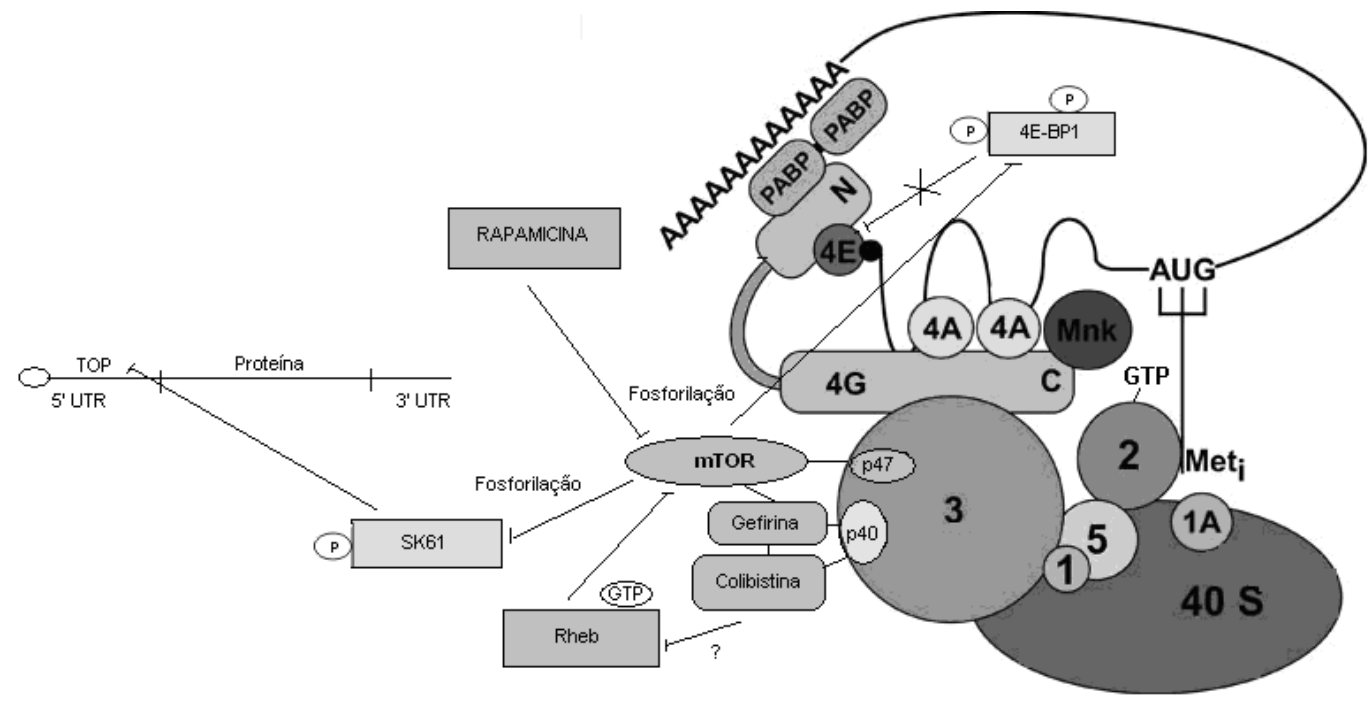

Figura 6. Modelo de interação entre os complexos de mTOR e de iniciação de tradução de eucariotos (eIF). Também estão representadas as interações de colibistina e gefirina com eIF3-p40, como também uma possível função da proteína colibistina na ativação da GTPase Rheb. (40S) subunidade ribossomal 40S, (1) eIF1, (2) eIF2, (3) eIF3, (4A) eIF4A, (4E) eIF4E, (4G) eIF4G, (5) eIF5, (PABP) proteína de ligação à cauda poli-A. Met $_{\mathrm{i}}$ é o RNAt iniciador.

$\mathrm{O}$ início da tradução protéica em eucariotos compreende diversas etapas. Na etapa inicial o fator de iniciação eIF2, ligado a uma molécula de GTP, conecta o iniciador Met-tRNA ${ }_{i}{ }^{\text {Met }}$ à subunidade ribossomal $40 \mathrm{~S}$, formando o complexo de pré-iniciação 43S. Em seguida ocorre a formação do complexo eIF4F, que é um heterotrímero constituído pelos fatores de iniciação eIF4E, eIF4A e eIF4G. O fator eIF4E é responsável por ligar todo o complexo $43 \mathrm{~S}$ à porção CAP $\left(5^{\prime} \mathrm{m}^{7} \mathrm{GpppN}\right)$ do RNA mensageiro, formando o complexo 48S. eIF4A é uma helicase cuja função é desdobrar a estrutura secundária na região 5 ' não traduzida (UTR) do RNAm para facilitar a ligação e escaneamento pelo complexo 48S. Já eIF4G é uma proteína que agrupa eIF4E e eIF4A, como também a proteína de ligação a cauda poli-A - PABP, a quinase $\mathrm{MnK}$, e eIF3. eIF3 possui a função de se ligar ao complexo $43 \mathrm{~S}$ inibindo a ligação prematura da subunidade ribossomal $60 \mathrm{~S}$ e de aumentar a força de ligação do complexo 43S à região 5' do RNAm. Uma vez montado todo o complexo $48 \mathrm{~S}$ de préiniciação de tradução, ele é capaz de progredir pela região 5' UTR até encontrar o códon de início da tradução protéica AUG, onde a subunidade ribossomal 60S se une ao complexo descrito, formando o complexo 80S, e iniciando a formação de ligações peptídicas. O processo de tradução pode ser regulado em diferentes etapas. A proteína 4E-BP1 regula a tradução por meio de sua ligação com o fator de iniciação eIF4E. Quando 4E-BP1 está desfosforilada, ela se liga fortemente a eIF4E, e essa ligação inibi a tradução por bloquear a ligação de eIF4G à eIF4E. Quando 4E-BP1 é fosforilada por mTOR, a ligação com eIF4E é desfeita e a tradução estimulada. 
Tabela 1. Seqüências dos oligonucleotídeos iniciadores utilizados para amplificar toda a região codificadora das proteínas colibistina e gefirina para as clonagens nos vetores do sistema de duplo-híbrido em levedura (pGBKT7 e pGADT7). Também está mostrado o tamanho do produto amplificado.

\begin{tabular}{|l|c|c|c|}
\hline & Iniciador Forward $\left(\mathbf{5}^{\prime} \rightarrow \mathbf{3}^{\prime}\right)$ & Iniciador Reverse $\left(\mathbf{5}^{\prime} \rightarrow \mathbf{3}^{\prime}\right)$ & $\begin{array}{c}\text { Tamanho do } \\
\text { produto }(\mathbf{p b})\end{array}$ \\
\hline $\begin{array}{l}\text { Colibistina } \\
\text { F/R }\end{array}$ & ATGACGTTGCTGATCACTGG & TGCCTCCCTGTAGGTATCAT & 1560 \\
\hline $\begin{array}{l}\text { Gefirina } \\
\text { F/R }\end{array}$ & CATGGCGACCGAGGGAATGA & CCATCATAGCCGTCCAATGAC & 2313 \\
\hline
\end{tabular}

Tabela 2. Esquema das transformações da linhagem de levedura AH109 com o plasmídeo pGBKT7-colibistina juntamente com cada um dos plasmídeos pGADT7 contendo toda ou parte da região codificadora das proteínas candidatas a interagir com colibistina: Stathmin-like2, AHCYL1, SFRS14, Nesca, WBP5, PSMD2, eIF3-p40, ITGA3, e o controle positivo e negativo.

\begin{tabular}{|c|}
\hline pGBKT7-colibistina + pGADT7-STMN \\
\hline pGBKT7-colibistina + pGADT7-AHCYL1 \\
\hline pGBKT7-colibistina + pGADT7-SFRS14 \\
\hline pGBKT7-colibistina + pGADT7-Nesca \\
\hline pGBKT7-colibistina + pGADT7-WBP5 \\
\hline pGBKT7-colibistina + pGADT7-PSMD2 \\
\hline pGBKT7-colibistina + pGADT7-eIF3-p40 \\
\hline pGBKT7-colibistina + pGADT7-ITGA3 \\
\hline pGBKT7-colibistina + pGADT7-gefirina (controle positivo) \\
\hline pGBKT7-colibistina + pGADT7- $\phi$ (controle negativo) \\
\hline
\end{tabular}


Tabela 3. Seqüências dos oligonucleotídeos iniciadores utilizados para amplificar toda a região codificadora das proteínas colibistina, gefirina e eIF3-p40 para as clonagens nos vetores de expressão em células de mamíferos pExchange e pcDNA3.1. Também está mostrado o tamanho do produto amplificado.

\begin{tabular}{|l|l|l|c|}
\hline & \multicolumn{1}{|c|}{ Iniciador Forward $\left(\mathbf{5}^{\prime} \rightarrow \mathbf{3}^{\prime}\right)$} & \multicolumn{1}{|c|}{ Iniciador Reverse $(\mathbf{5}, \boldsymbol{\rightarrow} \mathbf{3})$} & $\begin{array}{c}\text { Tamanho do } \\
\text { produto } \mathbf{( p b )}\end{array}$ \\
\hline $\begin{array}{l}\text { Colibistina } \\
\text { BamHI/XhoI }\end{array}$ & $\begin{array}{l}\text { CGGGATCCATGACGTTGCTG } \\
\text { ATCACT }\end{array}$ & $\begin{array}{l}\text { CGCTCGAGTCATTTTTTGA } \\
\text { AGGGGGT }\end{array}$ & 1566 \\
\hline $\begin{array}{l}\text { Gefirina } \\
\text { BamHI/XhoI }\end{array}$ & $\begin{array}{l}\text { CGGGCTCCATGGCGACCGAG } \\
\text { GGAATG }\end{array}$ & $\begin{array}{l}\text { CGCTCGAGTCATAGCCGT } \\
\text { CCAATACC }\end{array}$ & 2226 \\
\hline $\begin{array}{l}\text { eIF3-p40 } \\
\text { BamHI/XhoI }\end{array}$ & $\begin{array}{l}\text { CGGGATCCATGGCGTCCCGC } \\
\text { AAGGAA }\end{array}$ & $\begin{array}{l}\text { CGCTCGAGTTAGTTGTTGT } \\
\text { ATTCTTG }\end{array}$ & 1075 \\
\hline
\end{tabular}

Tabela 4. Esquema das transfecções realizadas em células HEK 293T com os plasmídeos contendo os cDNAs das proteínas colibistina, gefirina, eIF3-p40 e dos controles positivos e negativos.

\begin{tabular}{|c|}
\hline TRANSFECÇÕES DUPLAS \\
\hline pExchange4-eIF3-p40 + pcDNA3-colibistina (teste de interação) \\
\hline pExchange4-colibistina + pcDNA3-gefirina (controle positivo de interação) \\
\hline pExchange4-colibistina + pcDNA3- $\phi$ (controle negativo) \\
\hline pExchange4-eIF3-p40 + pcDNA3- $\phi$ (controle negativo) \\
\hline pExchange4-eIF3-p40 + pcDNA3-gefirina (teste de interação) \\
\hline TRANSFECÇÕES TRIPLAS \\
\hline pExchange4-eIF3-p40 + pExchange4-colibistina + pcDNA3-gefirina (teste de interação) \\
\hline pExchange4-eIF3-p40 + pExchange4-colibistina + pcDNA3- $\phi$ (controle negativo) \\
\hline
\end{tabular}

Tabela 5. Experimentos de co-imunoprecipitação in vivo para analisar interação de colibistina e gefirina com eIF3-p40 em cérebro de camundongo adulto.

\begin{tabular}{|c|c|c|}
\hline Experimento & Anticorpo Imunoprecipitação & Anticorpo Western blot \\
\hline A & anti-eIF3-p116(N-20) & anti-colibistina \\
\hline B & anti-eIF3-p116(N-20) & anti-gefirina \\
\hline
\end{tabular}


Tabela 6. Proteínas candidatas a interagir com a colibistina identificadas no sistema de duplo-híbrido em leveduras. Estão apresentados o número de clones identificados para cada proteína.

\begin{tabular}{|c|l|c|}
\hline $\begin{array}{c}\text { No. de acesso } \\
\text { GenBank }\end{array}$ & \multicolumn{1}{|c|}{ Nome do gene } & Clones \\
\hline BC006302 & Stathmin-like 2 (STMN2) & 2 \\
\hline AF315687 & Adenosylhomocysteine hydrolase-like protein (AHCYL1) & 1 \\
\hline BC020586 & Splicing factor, arginine/serine-rich 14 (SFRS14) & 1 \\
\hline BC001045 & RUN and SH3 domain containing 1 (Nesca) & 1 \\
\hline BC023544 & WW domain binding protein 5 (WBP5) & 1 \\
\hline NM_002808 & Proteasome (prosome, macropain) 26S subunit, non-ATPase, 2 (PSMD2) & 1 \\
\hline HSU54559 & Translation initiation factor eIF3 p40 subunit (eIF3 p40) & 1 \\
\hline NM_002204 & Integrin, alpha3 (ITGA3) & 1 \\
\hline
\end{tabular}




\section{Capítulo 6}

\section{Discussão Geral e Conclusões}

As doenças neurológicas são responsáveis pela morte de aproximadamente 7 milhões de pessoas por ano. A identificação de genes e de mecanismos moleculares associados com doenças neurológicas, além de contribuir para a melhor compreensão do funcionamento normal e em situações patológicas do sistema nervoso, é fundamental para a identificação de novos alvos terapêuticos e a criação de novos tratamentos, para o diagnóstico clínico e molecular mais preciso e para o aconselhamento genético de pacientes acometidos. Apesar dos grandes avanços obtidos na área do conhecimento das doenças neurológicas na última década, existem ainda muitas questões a serem respondidas.

Na primeira parte deste trabalho (Capítulo 3), utilizando as metodologias de estudo de ligação genética e análise de genes candidatos-posicionais, inicialmente mapeamos e restringimos o loco associado a uma grave forma de retardo mental sindrômico ligado ao cromossomo X em uma família Brasileira, e posteriormente identificamos o gene portador da mutação deletéria na família. O estudo de ligação genética, juntamente com a análise de genes candidatos-posicionais, tem sido amplamente utilizado para o mapeamento e identificação de genes associados com doenças humanas monogênicas, e tem contribuído significantemente com a identificação de muitos dos genes associados a doenças conhecidos até o momento. Com o estudo descrito no Capítulo 3, identificamos uma mutação de substituição de aminoácido no gene $S M S$ (p.G56S) nos pacientes da família Brasileira em estudo. A identificação dessa mutação contribuiu para: 1) a descrição da segunda família com a síndrome de Snyder-Robinson; 2) melhor caracterização do espectro de variabilidade clínica da síndrome; 3) aumentar a compreensão sobre o funcionamento da proteína espermina sintase; 4) a realização do aconselhamento genético preciso para essa família. Além desses resultados, verificamos que células neuronais transfectadas com vetores contendo a região codificadora da proteína espermina sintase mutada apresentaram redução dos prolongamentos neuronais, indicando que a proteína 
espermina sintase também apresenta uma função no controle da morfologia de células neuronais.

Na segunda parte do trabalho (Capítulo 4), utilizando as metodologias de dHPLC e seqüenciamento, analisamos o gene ARHGEF9 em 6 pacientes Brasileiros portadores de hiperecplexia e 22 pacientes Brasileiros portadores de retardo mental associado com epilepsia, e não identificamos alterações patogênicas. Durante o desenvolvimento deste estudo, três mutações foram descritas no gene ARHGEF9 em pacientes que possuem em comum retardo mental associado com outras anormalidades neurológicas, tais como hiperecplexia e epilepsia, e comportamentais, tais como agressão e ansiedade (Harvey et al., 2004; Marco et al., 2008; Kalscheuer et $a l .$, 2008). Com a descrição dessas mutações no gene ARHGEF9, a nossa hipótese de trabalho foi comprovada, na qual propusemos que mutações no gene ARHGEF9 poderiam ser responsáveis por causar hiperecplexia, epilepsia idiopática e retardo mental. Ainda, esses autores analisaram o gene ARHGEF9 em mais 31 pacientes com hiperecplexia (Harvey et al., 2004) e 576 pacientes do sexo masculino com retardo mental ligado ao cromossomo X não-sindrômico (99 casos familiais e 477 casos isolados) (Marco et al., 2008), e não encontraram nenhuma mutação patogênica adicional no gene ARHGEF9. Esses resultados sugerem que mutações no gene ARHGEF9 são raras em pacientes com retardo mental não-sindrômico. Por outro lado, uma mutação em ARHGEF9 foi encontrada entre os 38 pacientes com hiperecplexia analisados até o momento (32 pacientes analisados por Harvey et al. (2004) mais 6 pacientes analisados neste trabalho), ou seja, em 2,6\% dos casos analisados. Portando, o número de pacientes com hiperecplexia e com retardo mental associado com epilepsia analisados neste trabalho foi muito pequeno. Acreditamos que o estudo de um número maior de pacientes com essas doenças pode vir a revelar outras mutações patogênicas em ARHGEF9. Ainda, como nenhuma análise do gene ARHGEF9 foi realizada apenas em pacientes portadores de epilepsia, pode ser que mutações nesse gene estejam contribuindo para alguns dos casos de epilepsia, uma vez que das três mutações descritas em ARHGEF9 duas foram encontradas em pacientes apresentando episódios epilépticos.

$\mathrm{Na}$ terceira e última parte deste trabalho (Capítulo 5), utilizando as metodologias de duplo-híbrido em levedura e de co-imunoprecipitação in vitro e in vivo, identificamos duas novas interações protéicas localizadas nos sítios pós- 
sinápticos inibitórios do sistema nervoso central. A metodologia de duplo-híbrido tem sido bastante utilizada para a identificação de novas interações protéicas, mas também permite mapear os domínios de interação entre duas proteínas e analisar como mutações podem interferir na interação entre proteínas. Já a metodologia de coimunoprecipitação tem possibilitado confirmar os resultados obtidos por metodologias inicialmente utilizadas para a identificação de interações protéicas. A identificação de proteínas que interagem com uma proteína em estudo pode, sem dúvida, contribuir para a compreensão das funções dessa proteína. Assim sendo, com a utilização dessas metodologias citadas, identificamos as interações entre as proteínas colibistina e gefirina e a subunidade eIF3-p40 do complexo do fator 3 de iniciação de tradução protéica de eucariotos (eIF3). Esses resultados sugerem que colibistina e gefirina podem ter uma função no controle da tradução protéica nos sitos sinápticos. Essas interações, se realmente comprovadas, tem o potencial de ajudar a desvendar os mecanismos envolvidos na tradução protéica nos sítios pós-sinápticos inibitórios, processo recentemente associado com a plasticidade sináptica.

Em conclusão, esse trabalho contribuiu para aumentar o conhecimento e a compreensão sobre genes e mecanismos moleculares associados com certas doenças neurológicas, bem como sobre alguns dos mecansimos envolvidos no complexo funcionamento do sistema nervoso central. 


\section{Capítulo 7}

\section{Referências Bibliográficas}

Ausubel FM, Brent R, Kingston RE, Moore DD, Seidman JG. (1997) Current Protocols in Molecular Biology.

Alberts B, Bray D, Johnson A, Lewis J, Raff M, Roberts K, Walter P. (1999) Fundamentos da Biologia Celular - Uma introdução à biologia molecular da célula. Artmed editora

Andermann F, Keene DL, Andermann E, Quesney LF. (1980) Startle disease or hyperekplexia: further delineation of the syndrome. Brain 103(4):985-97

Baulac S, Huberfeld G, Gourfinkel-An I, Mitropoulou G, Beranger A, Prud'homme JF, Baulac M, Brice A, Bruzzone R, LeGuern E. (2001) First genetic evidence of $\operatorname{GABA}(\mathrm{A})$ receptor dysfunction in epilepsy: a mutation in the gamma2subunit gene. Nat Genet 28(1):46-8

Beck C, Moulard B, Steinlein O, Guipponi M, Vallee L, Montpied P, Baldy-Moulnier M, Malafosse A. (1994) A nonsense mutation in the alpha4 subunit of the nicotinic acetylcholine receptor (CHRNA4) cosegregates with 20q-linked benign neonatal familial convulsions (EBNI) Neurobiol Dis 1(1-2):95-9

Billuart P, Bienvenu T, Ronce N, des Portes V, Vinet MC. (1998) Oligophrenin-1 encodes a rhoGAP protein involved in $\mathrm{X}$-linked mental retardation. Nature 392(6679):923-6

Boettner B, Van Aelst L. (2002) The role of Rho GTPases in disease development. Gene 286(2):155-74

Bourne HR, Sanders DA, McCormick F. (1990) The GTPase superfamily: a conserved switch for diverse cell functions. Nature 348(6297):125-32

Butler AB, Hodos W. (1996) Comparative Vertebrate Neuroanatomy - Evolution and Adaptation. Wiley-Liss

Cerione RA, Zheng Y. (1996) The Dbl family of oncogenes. Curr Opin Cell Biol $8(2): 216-22$

Charlier C, Singh NA, Ryan SG, Lewis TB, Reus BE, Leach RJ, Leppert M. (1998) A pore mutation in a novel KQT-like potassium channel gene in an idiopathic epilepsy family. Nat Genet 18(1):53-5 
Chelly J, Khelfaoui M, Francis F, Chérif B, Bienvenu T. (2006) Genetics and pathophysiology of mental retardation. Eur J Hum Genet 14(6):701-13

Chiurazzi P, Hamel BC, Neri G. (2001) XLMR genes: update 2000. Eur J Hum Genet $9(2): 71-81$

Daniels RH, Bokoch GM. (1999) p21-activated protein kinase: a crucial component of morphological signaling? Trends Biochem Sci 24(9):350-5

D'Adamo P, Menegon A, Lo Nigro C, Grasso M, Gulisano M, Tamanini F, Bienvenu T, Gedeon AK, Oostra B, Wu SK, Tandon A, Valtorta F, Balch WE, Chelly J, Toniolo D. (1998) Mutations in GDI1 are responsible for X-linked non-specific mental retardation. Nat Genet 19(2):134-9

De Fusco M, Becchetti A, Patrignani A, Annesi G, Gambardella A, Quattrone A, Ballabio A, Wanke E, Casari G. (2000) The nicotinic receptor beta 2 subunit is mutant in nocturnal frontal lobe epilepsy. Nat Genet 26(3):275-6

Durand CM, Betancur C, Boeckers TM, Bockmann J, Chaste P, Fauchereau F, Nygren G, Rastam M, Gillberg IC, Anckarsäter H, Sponheim E, GoubranBotros H, Delorme R, Chabane N, Mouren-Simeoni MC, de Mas P, Bieth E, Rogé B, Héron D, Burglen L, Gillberg C, Leboyer M, Bourgeron T. (2007) Mutations in the gene encoding the synaptic scaffolding protein SHANK3 are associated with autism spectrum disorders. Nat Genet 39(1):25-7

Durand CM, Kappeler C, Betancur C, Delorme R, Quach H, Goubran-Botros H, Melke J, Nygren G, Chabane N, Bellivier F, Szoke A, Schurhoff F, Rastam M, Anckarsäter H, Gillberg C, Leboyer M, Bourgeron T. (2006) Expression and genetic variability of PCDH11Y, a gene specific to Homo sapiens and candidate for susceptibility to psychiatric disorders. Am J Med Genet B Neuropsychiatr Genet 141B(1):67-70

Engel J Jr. (2001) A proposed diagnostic scheme for people with epileptic seizures and with epilepsy: report of the ILAE Task Force on Classification and Terminology. Epilepsia 42(6):796-803

Escayg A, MacDonald BT, Meisler MH, Baulac S, Huberfeld G, An-Gourfinkel I, Brice A, LeGuern E, Moulard B, Chaigne D, Buresi C, Malafosse A. (2000) Mutations of SCN1A, encoding a neuronal sodium channel, in two families with GEFS+2. Nat Genet 24(4):343-5

Etienne-Manneville S, Hall A. (2002) Rho GTPases in cell biology. Nature 420(6916): 629-35

Eunson LH, Rea R, Zuberi SM, Youroukos S, Panayiotopoulos CP, Liguori R, Avoni P, McWilliam RC, Stephenson JB, Hanna MG, Kullmann DM, Spauschus A. (2000) Clinical, genetic, and expression studies of mutations in the potassium channel gene KCNA1 reveal new phenotypic variability. Ann Neurol 48(4):64756 
Feng G, Tintrup H, Kirsch J, Nichol MC, Kuhse J. (1998) Dual requirement for gephyrin in glycine receptor clustering and molybdoenzyme activity. Science 282(5392):1321-4

Fields S, Song O. (1989) A novel genetic system to detect protein-protein interactions. Nature 340(6230):245-6

Fuhrmann JC, Kins S, Rostaing P, El Far O, Kirsch J, Sheng M, Triller A, Betz H, Kneussel M. (2002) Gephyrin interacts with Dynein light chains 1 and 2, components of motor protein complexes. J Neurosci 22(13):5393-402

Giesemann T, Schwarz G, Nawrotzki R, Berhorster K, Rothkegel M, Schluter K, Schrader N, Schindelin H, Mendel RR, Kirsch J, Jockusch BM. (2003) Complex formation between the postsynaptic scaffolding protein gephyrin, profilin, and Mena: a possible link to the microfilament system. $J$ Neurosci 23(23):8330-9

Gitaí DL, Romcy-Pereira RN, Gitaí LL, Leite JP, Garcia-Cairasco N, Paço-Larson ML. (2008) Genes and epilepsy I: epilepsy and genetic alterations. Rev Assoc Med Bras 54(3):272-8

Grosskreutz Y, Hermann A, Kins S, Fuhrmann JC, Betz H, Kneussel M. (2001) Identification of a gephyrin-binding motif in the GDP/GTP exchange factor collybistin. Biol Chem 382(10):1455-62

Harvey K, Duguid IC, Alldred MJ, Beatty SE, Ward H, Keep NH, Lingenfelter SE, Pearce BR, Lundgren J, Owen MJ, Smart TG, Luscher B, Rees MI, Harvey RJ. (2004) The GDP-GTP exchange factor collybistin: an essential determinant of neuronal gephyrin clustering. J Neurosci 24(25): 5816-26

Haug K, Hallmann K, Rebstock J, Dullinger J, Muth S, Haverkamp F, Pfeiffer H, Rau B, Elger CE, Propping P, Heils A. (2001) The voltage-gated sodium channel gene SCN2A and idiopathic generalized epilepsy. Epilepsy Res 47(3):243-6

Haug K, Warnstedt M, Alekov AK, Sander T, Ramírez A, Poser B, Maljevic S, Hebeisen S, Kubisch C, Rebstock J, Horvath S, Hallmann K, Dullinger JS, Rau B, Haverkamp F, Beyenburg S, Schulz H, Janz D, Giese B, Müller-Newen G, Propping P, Elger CE, Fahlke C, Lerche H, Heils A. (2003) Mutations in CLCN2 encoding a voltage-gated chloride channel are associated with idiopathic generalized epilepsies. Nat Genet 33(4):527-32

Ishikawa K, Nagase T, Nakajima D, Seki N, Ohira M. (1997) Prediction of the coding sequences of unidentified human genes. 78 new cDNA clones from brain which code for large proteins in vitro. DNA Res 4(5):307-313

Jamain S, Quach H, Betancur C, Råstam M, Colineaux C, Gillberg IC, Soderstrom H, Giros B, Leboyer M, Gillberg C, Bourgeron T; Paris Autism Research International Sibpair Study. (2003) Mutations of the X-linked genes encoding 
neuroligins NLGN3 and NLGN4 are associated with autism. Nat Genet 34(1):27-9

Johnston MV. (2004) Clinical disorders of brain plasticity. Brain Dev 26(2):73-80

Kalscheuer VM, Musante L, Fang C, Hoffmann K, Fuchs C, Carta E, Deas E, Venkateswarlu K, Menzel C, Ullmann R, Tommerup N, Dalprà L, Tzschach A, Selicorni A, Lüscher B, Ropers HH, Harvey K, Harvey RJ. (2008) A balanced chromosomal translocation disrupting ARHGEF9 is associated with epilepsy, anxiety, aggression, and mental retardation. Hum Mutat [Epub ahead of print]

Kaneko S, Okada M, Iwasa H, Yamakawa K, Hirose S. (2002) Genetics of epilepsy: current status and perspectives. Neurosci Res 44(1):11-30

Kins S, Betz H, Kirsch J. (2000) Collybistin, a newly identified brain-specific GEF, induces submembrane clustering of gephyrin. Nat Neurosci 3(1):22-9

Kirsch J, Langosch D, Prior P, Littauer UZ, Schmitt B, Betz H. (1991) The 93-kDa glycine receptor-associated protein binds to tubulin. $J$ Biol Chem 266(33):22242-5

Kirsch J, Malosio ML, Wolters I, Betz H. (1993) Distribution of gephyrin transcripts in the adult and developing rat brain. Eur J Neurosci 5(9):1109-17

Kneussel M, Betz H. (2000) Receptors, gephyrin and gephyrin-associated proteins: novel insights into the assembly of inhibitory postsynaptic membrane specializations. J Physiol 525 (Pt 1):1-9

Kneussel M, Engelkamp D, Betz H. (2001) Distribution of transcripts for the brainspecific GDP/GTP exchange factor collybistin in the developing mouse brain. Eur J Neurosci 13(3): 487-92

Kutsche K, Yntema H, Brandt A, Jantke I, Nothwang HG. (2000) Mutations in ARHGEF6, encoding a guanine nucleotide exchange factor for Rho GTPases, in patients with X-linked mental retardation. Nat Genet 26(2): 247-50

Kuklin A, Munson K, Gjerde D, Haefele R, Taylor P. (1997) Detection of singlenucleotide polymorphisms with the WAVE DNA fragment analysis system. Genet Test 1(3):201-6

Laumonnier F, Bonnet-Brilhault F, Gomot M, Blanc R, David A, Moizard MP, Raynaud M, Ronce N, Lemonnier E, Calvas P, Laudier B, Chelly J, Fryns JP, Ropers HH, Hamel BC, Andres C, Barthélémy C, Moraine C, Briault S. (2004) $\mathrm{X}$-linked mental retardation and autism are associated with a mutation in the NLGN4 gene, a member of the neuroligin family. Am J Hum Genet 74(3):552-7

Lemmon MA, Ferguson KM. (2000) Signal-dependent membrane targeting by pleckstrin homology (PH) domains. Biochem J 350 (Pt 1): 1-18 
Luo L. (2000) Rho GTPases in neuronal morphogenesis. Nat Rev Neurosci 1(3):17380

Luo L, Jan LY, Jan YN. (1997) Rho family GTP-binding proteins in growth cone signalling. Curr Opin Neurobiol 7(1): 81-6

Lynch JW, Rajendra S, Pierce KD, Handford CA, Barry PH, Schofield PR. (1997) Identification of intracellular and extracellular domains mediating signal transduction in the inhibitory glycine receptor chloride channel. EMBO J 16(1):110-20

Maniatis T, Fritseh EF, Sambrook J. (1982) Molecular Cloning. A Laboratory Manual, Cold Spring Harbor Laboratory, New York

Maranduba CM. (2005) Estudo molecular do retardo rental de herança ligada ao cromossomo X. Tese de doutorado. Instituto de Biociências, Universidade de São Paulo, SP, Brasil.

Marco EJ, Abidi FE, Bristow J, Dean WB, Cotter P, Jeremy RJ, Schwartz CE, Sherr EH. (2008) ARHGEF9 disruption in a female patient is associated with $\mathrm{X}$ linked mental retardation and sensory hyperarousal. J Med Genet 45(2):100-5

Maljevic S, Krampfl K, Cobilanschi J, Tilgen N, Beyer S, Weber YG, Schlesinger F, Ursu D, Melzer W, Cossette P, Bufler J, Lerche H, Heils A. (2006) A mutation in the GABA(A) receptor alpha(1)-subunit is associated with absence epilepsy. Ann Neurol 59(6):983-7

Mammoto A, Sasaki T, Asakura T, ,Hotta I, Imamura H, Takahashi K, Matsuura Y, Shirao T, Takai Y. (1998) Interactions of drebrin and gephyrin with profilin. Biochem Biophys Res Commun 243(1):86-9

Mielke K, Herdegen T. (2000) JNK and p38 stresskinases--degenerative effectors of signal-transduction-cascades in the nervous system. Prog Neurobiol 61(1):4560

Miller SA, Dykes DD, Polensky HF. (1988) A simple salting out procedure for extracting DNA from human nucleated cells. Nucleic Acids Res 16(3):1215

Negishi M, Katoh H. (2002) Rho family GTPases as key regulators for neuronal network formation. J Biochem (Tokyo) 132(2): 157-66

Noebels JL. (2003) The biology of epilepsy genes. Annu Rev Neurosci 26:599-625

Papadopoulos T, Korte M, Eulenburg V, Kubota H, Retiounskaia M, Harvey RJ, Harvey K, O'Sullivan GA, Laube B, Hülsmann S, Geiger JR, Betz H. (2007) Impaired GABAergic transmission and altered hippocampal synaptic plasticity in collybistin-deficient mice. EMBO J 26(17):3888-99 
Papadopoulos T, Eulenburg V, Reddy-Alla S, Mansuy IM, Li Y, Betz H. (2008) Collybistin is required for both the formation and maintenance of GABAergic postsynapses in the hippocampus. Mol Cell Neurosci [Epub ahead of print]

Price DL. (1999) New order from neurological disorders. Nature 399(6738 Suppl):A3-5

Rees MI, Harvey K, Pearce BR, Chung SK, Duguid IC, Thomas P, Beatty S, Graham GE, Armstrong L, Shiang R, Abbott KJ, Zuberi SM, Stephenson JB, Owen MJ, Tijssen MA, van den Maagdenberg AM, Smart TG, Supplisson S, Harvey RJ. (2006) Mutations in the gene encoding GlyT2 (SLC6A5) define a presynaptic component of human startle disease. Nat Genet 38(7):801-6

Rees MI, Harvey K, Ward H, White JH, Evans L, Duguid IC, Hsu CC, Coleman SL, Miller J, Baer K, Waldvogel HJ, Gibbon F, Smart TG, Owen MJ, Harvey RJ, Snell RG. (2003) Isoform heterogeneity of the human gephyrin gene (GPHN), binding domains to the glycine receptor, and mutation analysis in hyperekplexia. J Biol Chem 278(27):24688-96

Rees MI, Lewis TM, Kwok JBJ, Mortier GR, Govaert P. (2002) Hyperekplexia associated with compound heterozygote mutations in the beta-subunit of the human inhibitory glycine receptor (GLRB). Hum. Molec Genet 11: 853-860

Rees MI, Lewis TM, Vafa B, Ferrie C, Corry P. (2001) Compound heterozygosity and nonsense mutations in the alpha-1-subunit of the inhibitory glycine receptor in hyperekplexia. Hum Genet 109: 267-270

Reid T, Bathoorn A, Ahmadian MR, Collard JG. (1999) Identification and characterization of hPEM-2, a guanine nucleotide exchange factor specific for Cdc42. J Biol Chem 274(47):33587-93

Ropers HH, Hamel BC. (2005) X-linked mental retardation. Nat Rev Genet 6(1):4657

Sabatini DM, Barrow RK, Blackshaw S, Burnett PE, Lai MM, Field ME, Bahr BA, Kirsch J, Betz H, Snyder SH. (1999) Interaction of RAFT1 with gephyrin required for rapamycin-sensitive signaling. Science 284(5417):1161-4

Saiki RK, Scharf S, Falooma F, Mullis KB, Horn GT. (1985) Enzymatic amplification of B-globin sequences and restriction site analysis for diagnosis of sickle cell anemia. Science 230:1350-1354

Schwartz CE, Stevenson RE, Schroer RJ. (2008) http://www.ggc.org/xlmr.htm

Shiang R, Ryan SG, Zhu YZ, Fielder TJ, Allen RJ, Fryer A, Yamashita S, O'Connell P, Wasmuth JJ. (1995) Mutational analysis of familial and sporadic hyperekplexia. Ann Neurol 38(1):85-91 
Shiang R, Ryan SG, Zhu YZ, Hahn AF, O'Connell P, Wasmuth JJ. (1993) Mutations in the alpha 1 subunit of the inhibitory glycine receptor cause the dominant neurologic disorder, hyperekplexia. Nat Genet 5(4):351-8

Singh NA, Charlier C, Stauffer D, DuPont BR, Leach RJ, Melis R, Ronen GM, Bjerre I, Quattlebaum T, Murphy JV, McHarg ML, Gagnon D, Rosales TO, Peiffer A, Anderson VE, Leppert M. (1998) A novel potassium channel gene, KCNQ2, is mutated in an inherited epilepsy of newborns. Nat Genet 18(1):25-9

Squire LR, Roberts JL, Spitzer NC, Zigmond MJ, McConnell SK, Bloom FE. (2002) Fundamental Neuroscience, Second Edition. Academic Press

Stallmeyer B, Schwarz G, Schulze J, Nerlich A, Reiss J, Kirsch J, Mendel RR. (1999) The neurotransmitter receptor-anchoring protein gephyrin reconstitutes molybdenum cofactor biosynthesis in bacteria, plants, and mammalian cells. Proc Natl Acad Sci U S A 96(4):1333-8

Stevenson RE, Schwartz CE. (2002) Clinical and molecular contributions to the understanding of X-linked mental retardation. Cytogenet Genome Res 99(14):265-75

Suhren O, Bruyn GW, Tuynman A. (1966) Hyperexplexia, a hereditary startle syndrome. J Neurol Sci 3:577-605

Tabolacci E, Pomponi MG, Pietrobono R, Terracciano A, Chiurazzi P, Neri G. (2006) A truncating mutation in the IL1RAPL1 gene is responsible for X-linked mental retardation in the MRX21 family. Am J Med Genet 140(5):482-7

Vaillend C, Poirier R, Laroche S. (2008) Genes, plasticity and mental retardation. Behav Brain Res 192(1):88-105

Vandesompele J, De Preter K, Pattyn F, Poppe B, Van Roy N, De Paepe A, Speleman F. (2002) Accurate normalization of real-time quantitative RT-PCR data by geometric averaging of multiple internal control genes. Genome Biol 3(7):RESEARCH0034

Vergouwe MN, Tijssen MA, Shiang R, van Dijk JG, al Shahwan S, Ophoff RA, Frants RR. (1997) Hyperekplexia-like syndromes without mutations in the GLRA1 gene. Clin Neurol Neurosurg 99(3):172-8

Wallace RH, Wang DW, Singh R, Scheffer IE, George AL Jr, Phillips HA, Saar K, Reis A, Johnson EW, Sutherland GR, Berkovic SF, Mulley JC. (1998) Febrile seizures and generalized epilepsy associated with a mutation in the Na+-channel beta1 subunit gene SCN1B. Nat Genet 19(4):366-70

Wherlock M, Mellor H. (2002) The Rho GTPase family: a Racs to Wrchs story. J Cell Sci 115(Pt 2):239-40 
Wisden W, Laurie DJ, Monyer H, Seeburg PH. (1992) The distribution of 13 GABAA receptor subunit mRNAs in the rat brain. I. Telencephalon, diencephalon, mesencephalon. J Neurosci 12(3):1040-62

Xiao W, Oefner PJ. (2001) Denaturing high-performance liquid chromatography: A review. Hum Mutat 17(6):439-74

Zhou L, Chillag KL, Nigro MA. (2002) Hyperekplexia: a treatable neurogenetic disease. Brain Dev 24(7):669-74 
Anexos e Apêndices 
New SMS mutation leads to a striking reduction in spermine synthase protein function and a severe form of SnyderRobinson X-linked recessive mental retardation syndrome

G de Alencastro, D E McCloskey, S E Kliemann, C M C Maranduba, A E Pegg, X Wang, D R Bertola, C E Schwartz, M R Passos-Bueno and A L Sertié

J. Med. Genet. 2008;45;539-543; originally published online 11 Jun 2008; doi:10.1136/jmg.2007.056713

Updated information and services can be found at:

http://jmg.bmj.com/cgi/content/full/45/8/539

These include:

References This article cites 9 articles, 3 of which can be accessed free at: http://jmg.bmj.com/cgi/content/full/45/8/539\#BIBL

Rapid responses You can respond to this article at: http://jmg.bmj.com/cgi/eletter-submit/45/8/539

Email alerting Receive free email alerts when new articles cite this article - sign up in the box at service the top right corner of the article

Notes

To order reprints of this article go to:

http://journals.bmj.com/cgi/reprintform

To subscribe to Journal of Medical Genetics go to:

http://journals.bmj.com/subscriptions/ 


\title{
New SMS mutation leads to a striking reduction in spermine synthase protein function and a severe form of Snyder-Robinson X-linked recessive mental retardation syndrome
}

\author{
G de Alencastro, ${ }^{1}$ D E McCloskey, ${ }^{2}$ S E Kliemann, ${ }^{3}$ C M C Maranduba, ${ }^{1}$ A E Pegg, ${ }^{2}$ \\ X Wang, ${ }^{2}$ D R Bertola, ${ }^{4}$ C E Schwartz, ${ }^{5}$ M R Passos-Bueno, ${ }^{1}$ A L Sertié ${ }^{1}$
}

\begin{abstract}
${ }^{1}$ Centro de Estudos do Genoma Humano, Departamento de Genética e Biologia Evolutiva, Instituto de Biociências, Universidade de São Paulo, Brazil; ${ }^{2}$ Department of Cellular and Molecular Pathology, Penn State University College of Medicine, Hershey,

Pennsylvania, USA; ${ }^{3}$ Associação Cruz Verde, São Paulo, Brazil; ${ }^{4}$ Instituto da Criança do Hospital das Clínicas, Faculdade de Medicina, USP, São Paulo, Brazil; ${ }^{5}$ J.C. Self Research Institute of Human Genetics, Greenwood Genetic Center, Greenwood, South

Carolina, USA
\end{abstract}

Correspondence to: Dr A Laurato Sertié, Rua do Matão 277. Depto. Genética e Biologia Evolutiva, Instituto de Biociências, USP, São Paulo, SP, 05508-900, Brazil asertie@hotmail.com

Received 6 December 2007 Revised 2 May 2008 Accepted 12 May 2008 Published Online First 11 June 2008

\section{ABSTRACT}

We report the identification of a novel mutation at a highly conserved residue within the $\mathrm{N}$-terminal region of spermine synthase (SMS) in a second family with Snyder-Robinson X-linked mental retardation syndrome (OMIM 309583). This missense mutation, p.G56S, greatly reduces SMS activity and leads to severe epilepsy and cognitive impairment. Our findings contribute to a better delineation and expansion of the clinical spectrum of Snyder-Robinson syndrome, support the important role of the N-terminus in the function of the SMS protein, and provide further evidence for the importance of SMS activity in the development of intellectual processing and other aspects of human development.

In 1969, Snyder and Robinson described a large family affected by X-linked recessive mental retardation (XLMR), hypotonia and unsteady gait (Snyder-Robinson syndrome (SRS), OMIM 309583). ${ }^{1}$ In 1996, Arena et $a l^{2}$ re-evaluated five affected adult males and evaluated an additional 2year-old boy. They observed a characteristic combination of clinical features including mild-tomoderate mental retardation, facial asymmetry of the lower face and orbital region, thickened lower lip, nasal dysarthric and/or slow speech, thin habitus with diminished muscle bulk, osteoporosis, kyphoscoliosis, and long hands with hyperextensible fingers. Other less consistent symptoms included seizures, pectus excavatum, cleft or high arched palate, and long great toes. Signs of the syndrome seem to develop gradually as many of the described clinical findings were only observed in adults. The causative gene was mapped by linkage analysis on Xp22.1.

More recently, Cason et $a l^{3}$ identified a splice mutation in the spermine synthase (SMS) gene in affected males of this family. SMS encodes a protein of 366 amino acids that catalyses the production of the polyamine spermine from the shorter chain length polyamine, spermidine. Polyamines, ubiquitously present in eukaryotes, are simple molecules that interact with a variety of macromolecules and play important roles in cell growth and differentiation as well as in neurological function. ${ }^{4}$ The crystal structure and functional domains of SMS have recently been characterised. The C-terminal portion of the protein, residues $173-366$, seems to contain the active site, and the $\mathrm{N}$-terminal domain located at residues 1-117 seems to be essential for activity and dimerisation. ${ }^{5}$ The splice site mutation identified in the original SRS family resulted in the loss of the C-terminal active site, a substantial reduction in SMS activity ( $\sim 5 \%$ of control), and an increase in the spermidine/spermine ratio (2.5-fold of control) in cell lines. ${ }^{3}$

We report the identification of a second SMS mutation, a missense mutation in the N-terminal domain of the protein which greatly reduces its enzyme activity in lymphoblastoid cells and is associated with a severe form of Snyder-Robinson XLMR syndrome.

\section{CASE REPORT}

The family is a large white Brazilian kindred (fig 1A). Clinical findings, summarised in table 1, were obtained for three affected males: III-2, III-11 and IV-3. There was a pronounced clinical variability among the patients and no abnormal phenotypes were noted in obligate carriers.

Patient III-2, the proband, was born at term, after an uneventful pregnancy, with a birth weight of $3050 \mathrm{~g}$ (50-75th centile), length of $50 \mathrm{~cm}$ (50th centile), and head circumference of $35 \mathrm{~cm}$ (50th centile). He had global developmental delay: he held his head up at 2 years of age, sat without support at 3 years and walked with assistance at the age of 5 . Myoclonic-like seizures developed at the age of 2 years. Currently, at the age of 12 years (fig $1 \mathrm{~B}$ ), he has profound mental retardation, absent speech, generalised tonic-clonic and absence seizures treated with valproic acid, carbamazepine and nitrazepan, and is unable to stand alone or walk. On physical examination he weighed $20.10 \mathrm{~kg}$ ( $<3 \mathrm{rd}$ centile), was $128 \mathrm{~cm}$ ( $<3 \mathrm{rd}$ centile) tall, and had a head circumference of $52 \mathrm{~cm}$ (50th centile). A slight facial dysmorphism was noted with mild hypertelorism and exophthalmia, short philtrum, thickened lower lip, slight high arched palate, mandibular prognathism, and ears with prominent antihelices and hypoplastic lobules. He has normal hearing and a pronounced myopia (-8/-9 dpt). Other relevant findings include: pectus carinatum, cryptorchidism, severe kyphoscoliosis, and camptodactyly without aracnodactyly. No foot abnormalities were observed. He has pronounced muscular hypotonia, diminished muscle bulk and decreased subcutaneous fat. Complementary examinations disclosed a normal electrocardiogram (ECG) and echocardiogram and an ectopic right kidney on abdominal ultrasound 
A

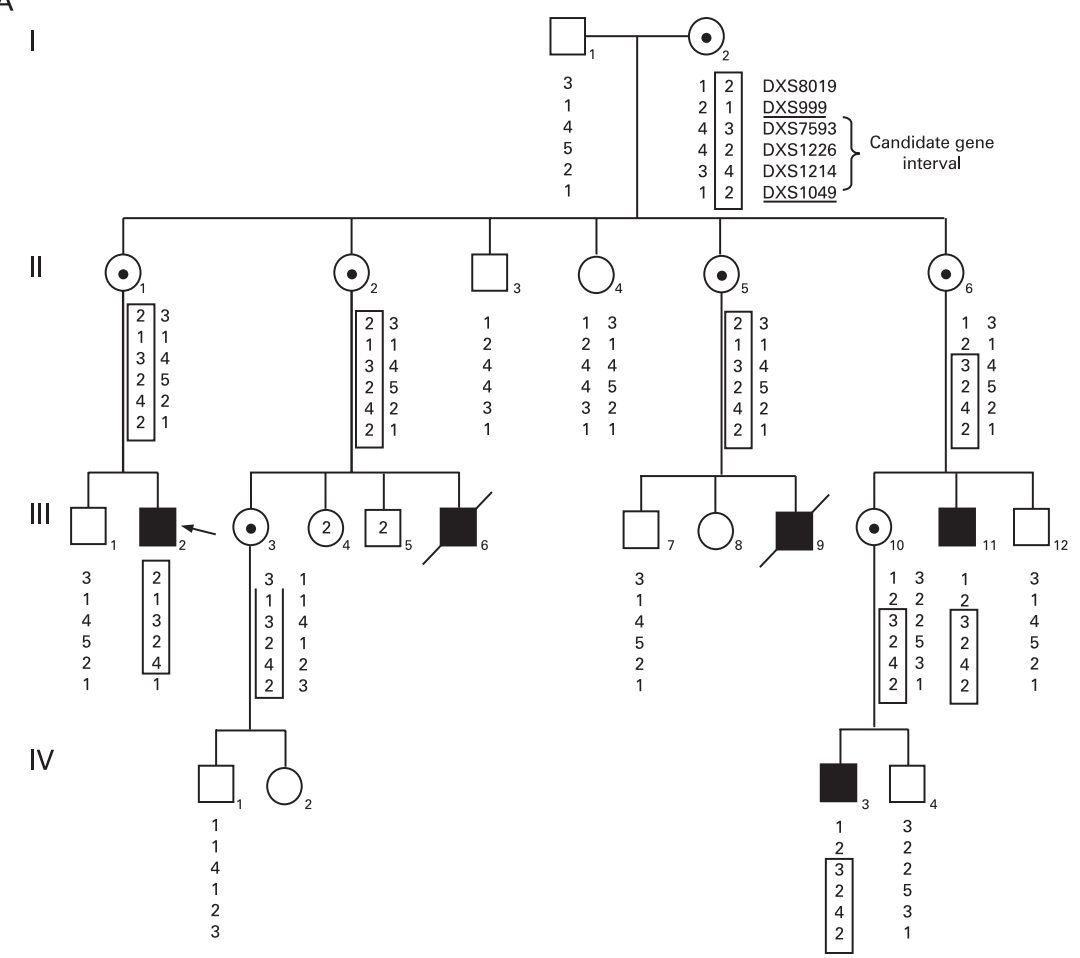

C

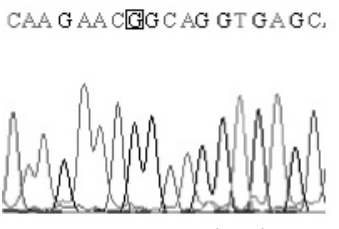

Healthy male (III-1)
CAA G AAC $₫ G C A G$ GT GAGC.

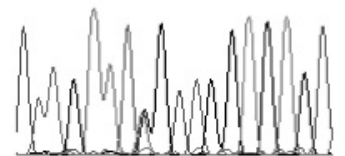

Obligate carrier (II-1)
B (III-2)
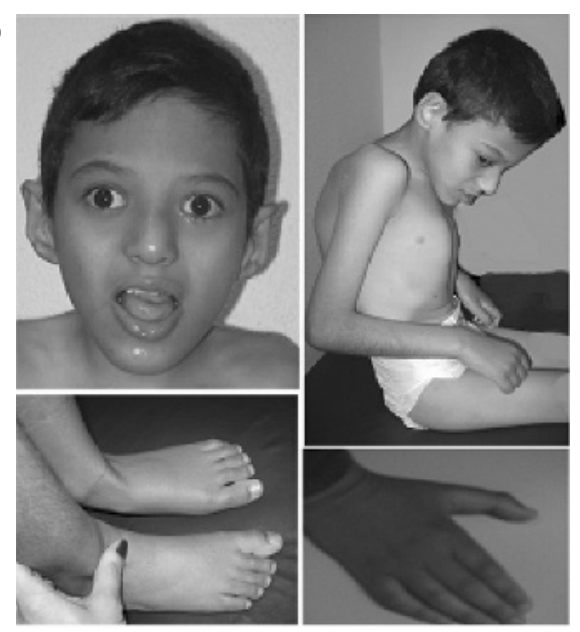

(III-11)
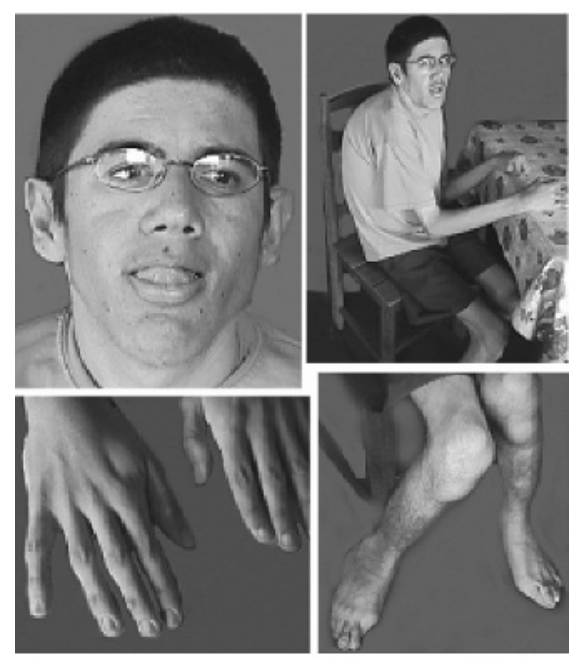

(IV-3)
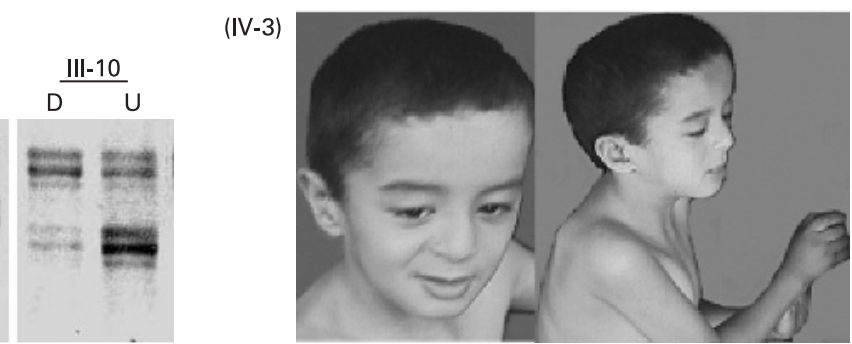

Affected male (III-2)

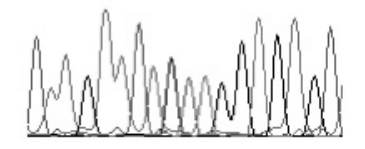

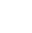

D

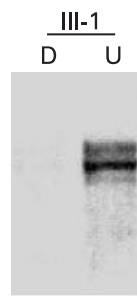

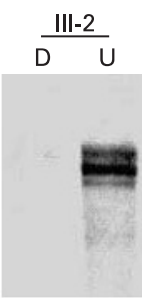
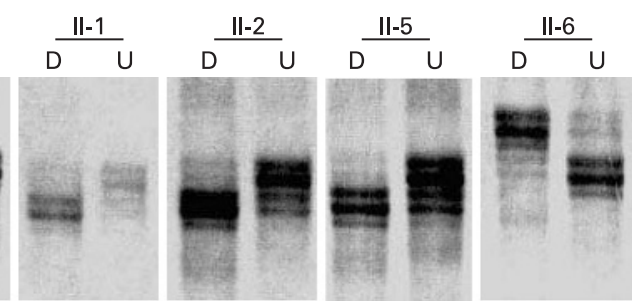

Figure 1 (A) Partial pedigree of the family. Black symbols represent affected individuals, and symbols with dots represent carriers. The index patient is indicated with an arrow. Detailed clinical data for this study were obtained from three patients (III-2, III-11 and IV-3), but according to reports given by family members, patients III-6 and III-9 also suffered from profound mental retardation with absent speech and severe seizures. Haplotypes of the X chromosome markers linked to the disease gene are shown. The at-risk haplotype is indicated by rectangles. Individuals II-6 and III-2 define the centromeric and telomeric borders of linkage interval respectively. (B) Photographs of the three affected males: III-2 (12 years old), III-11 (23 years old) and IV-3 (6 years old). (C) Partial sequence chromatrograms of exon 2 of SMS in a healthy male from the family (III-1), an obligate carrier (III-1) and an affected male (III-2). The position of the mutation (c.267G $>$ A) is indicated by a square frame. Primer sequences and conditions are available on request. It is noteworthy that although this mutation is located three base pairs before the $3^{\prime}$ splice site of exon 2, it does not seem to affect splicing in peripheral leucocytes of affected patients, since only one reverse transcriptase-polymerase chain reaction (RT-PCR) fragment of normal size and intensity was observed on agarose gel electrophoresis using primers located on exons 1 and 6 of the gene and direct sequencing of this product revealed proper splicing. (D) Skewed X chromosome inactivation (XCI) pattern observed in peripheral leucocytes of carriers with the c.267G $>$ A SMS mutation. XCI pattern was determined by amplification of the androgen receptor CAG repeat polymorphism using genomic DNA undigested and digested with Hpall, indicated by $\mathrm{U}$ and $\mathrm{D}$, respectively. DNA on the inactive $\mathrm{X}$ chromosome is resistant to Hpall digestion and thus can be amplified with primers flanking the restriction site. DNA on the active X chromosome, as in individuals III- 1 and III-2, is cleavable by Hpall and gives no detectable PCR product in the D fractions. XCI was skewed towards one chromosome in II-1, II-2, II-5, II-6 and III-10.

Skeletal survey showed generalised osteopenia, platyspondyly and dorso lumbar kyphoscoliosis. Magnetic resonance imaging revealed no obvious structural abnormalities but the presence of small bilateral pallidal calcifications. Karyotype and molecular evaluation for FraX syndrome were negative.
Patient III-11 was born at term after an uneventful pregnancy and delivery with a birth weight of $2800 \mathrm{~g}$ (10th centile) and length of $51 \mathrm{~cm}$ (50-75th centile). He also showed delayed motor development: he sat at 1 year, crawled at 2 years, and never walked unassisted. His cognitive impairment was milder 
Table 1 Summary of phenotypes observed in affected males of the reported Brazilian family. Detailed clinical data for this study were obtained from three patients (III-2, III-11 and IV-3). A summary of the clinical features observed in the patients of the originally reported SRS family is also shown

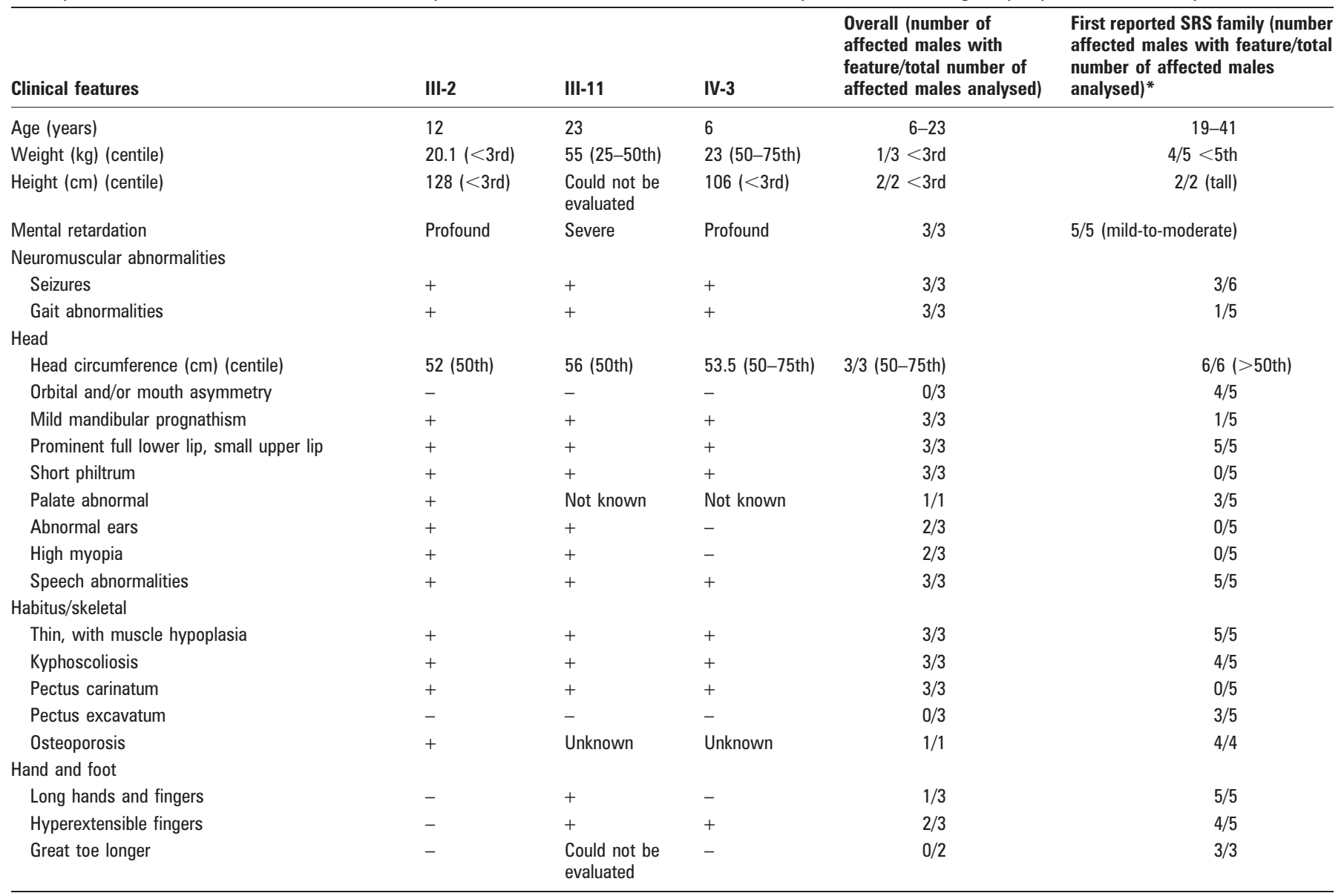

SRS, Snyder-Robinson syndrome; + present; - absent.

*The original family was first reported by Snyder and Robinson. ${ }^{1}$ It was re-evaluated by Arena et a/ ${ }^{2}$ who provided a more detailed clinical description of five adult males and an additional affected male, 2 years of age. Although clinical data for infancy are not shown, all affected individuals showed delayed development.

than that observed in his two affected relatives (III-2 and IV-3). He began to speak single words at 5 years old. At the age of 15 he developed generalised seizures. Currently, at the age of 23 (fig 1B), he has severe mental retardation; he cannot read or write but he understands simple commands and repeats names. His speech is nasal and slow. His seizures have been treated with carbamazepine, phenobarbital and clobazan. On physical examination he weighed $55 \mathrm{~kg}$ (25-50th centile) and had a head circumference of $56 \mathrm{~cm}$ (50th centile). His height could not be evaluated adequately due to severe kyphoscoliosis. His face was long and coarse with large, open mouth, thickened lower lip, short philtrum, mandibular prognathism and ears with deficient antihelical folding. He has normal hearing and myopia (-4.5). His other findings included: pectus carinatum, severe limb joint contractures, long and hyperextensible fingers and halluces valgi and under other toes. He has pronounced muscular hypotonia, diminished muscle bulk and decreased subcutaneous fat. His motor coordination and strength seem to be normal. He has not been evaluated for osteoporosis, but he has never had a fracture. Cranial computed tomography and ECG were normal.

Patient IV-3 was born at term after an uncomplicated pregnancy and delivery with a birth weight of $3100 \mathrm{~g}$ (5075 th centile) and a length of $49 \mathrm{~cm}$ (10-25th centile). His psychomotor development was also severely delayed. He sat at 2 years, crawled at 3 years, and started walking a few steps, unassisted, at 5 years old. At the age of 2 he developed generalised seizures. Currently, at age 6 (fig 1B), he has severe mental retardation, absent speech, intense agitation and seizures treated with phenobarbital and neuleptil. He can walk for short distances with a wide based gait characterised by irregularity and unsteadiness. On physical examination, he weighed $23.0 \mathrm{~kg}$ (25-50th centile), had a height of $106 \mathrm{~cm}$ (2.5th centile) and a head circumference of $53.5 \mathrm{~cm}$ (50-98th centile). Facial features included high and broad forehead, slight thickened lower lip, slight mandibular prognathism, and a pronounced septal deviation. He has normal hearing and visual acuity. Other important findings are: pectus carinatum, moderate kyphoscoliosis, muscular hypotonia, diminished muscle bulk, but normal muscle strength. The hands are normal but with hyperextensible fingers. No foot abnormalities were observed. He has not been evaluated for osteoporosis, but he has never had a fracture. Cranial computed tomography and ECG were reported as normal.

\section{RESULTS AND DISCUSSION}

We observed that our patients shared phenotypic features with those reported in the original Snyder-Robinson syndrome family. However, some other aspects of the phenotype were distinct (table 1) which did not allow us to confirm the diagnosis based only on clinical analysis. Linkage analysis of our Brazilian family, using 23 microsatellite markers distributed in the X chromosome, indicated linkage to Xp22-Xp21.1, between 
A

Sample

Normal female control

Patient from the first reported SRS family

Female carrier II-6

Patient III-2

Patient III-11

Patient IV-3

B

Sample

Patient III-2

Normal female control

Putrescine
$\begin{gathered}0.32 \\ 0.87\end{gathered}$

C

Human
Chicken
Cow
Lizard
Dog
Rat
Mouse
Opossum
Xenopus
Fugu

Spermine synthase activity

(pmol/h/mg protein)

500

634

$<1$

$<1$

$<1$

G56S
GYLATYTNKNGSFANLRIYPH
GYLATYIKKNGSFANLRIHPH
GYLATYINKN GFANLRIYPH
GYLATYVNKN GSFANLRIYPH
GYLATYINKN GSFANLRIYPH
GYLATYTNKN GFANLRIYPH
GYLATYTNKN GSFANLRIYPH
GYLATYINKN GSFASLRIYPH
GYLATYTGKK GSFATVRIYPH
GYLATLVGKH GRALLRVHSH

Figure 2 (A) Levels of spermine synthase (SMS) activity in lymphoblastoid cell lines in one control individual of the population, one affected patient of the first reported SRS family (splice mutation: $G>A$ at position +5 of the $5^{\prime}$ splice site of intron 4$){ }^{3}$ one female carrier (II-6), and three affected males (III-2, III-11 and IV-3) of the family described here (p.G56S mutation). SMS activity was determined by measuring the production of [ ${ }^{35}$ S] methylthioadenosine from $\left[{ }^{35} \mathrm{~S}\right]$ decarboxylated AdoMet in the presence of $0.5 \mathrm{mM}$ spermidine as previously described. ${ }^{3}$ (B) Polyamine content in lymphoblastoid cell lines from a normal control and an affected male III-2 of the family described here (p.G56S SMS mutation). Spermidine is synthesised from putrescine by spermidine synthase and spermidine is further metabolised to spermine by spermine synthase (SMS). Polyamines were separated and quantified by high performance liquid chromatography (HPLC) using a post-column derivatisation method to form fluorescent products. ${ }^{3}$ (C) ClustalW protein alignments of vertebrate SMS orthologues. Only partial sequences, corresponding to residues 46-66 of human SMS protein, are shown. The missense mutation is detected and its position is indicated by an arrow. The glycine (G) residue at position 56 is highly conserved, and outlined with a box.

markers DXS999 and DXS1049, with a maximum lod score of 2.9 at marker DXS1226 (fig 1A). This region contains the SMS gene, making SMS the best candidate gene.

Reverse transcriptase-polymerase chain reaction (RT-PCR) analysis using two pairs of primers designed to amplify the entire coding sequence of SMS was performed on CDNA isolated from peripheral leucocytes of the patients. Sequencing of the amplified cDNA revealed a c.267G $>$ A (reference sequence NM_004595) change in exon 2, which results in a missense mutation, p.G56S. By direct genomic sequencing of exon 2 using intronic primers flanking this exon, we confirmed that the mutation segregates with the disease phenotype in the family (fig 1C), consistent with the haplotype data that were derived from the linkage analysis. In addition, the mutation was not detected among $724 \mathrm{X}$ control chromosomes (448 males and 138 females), indicating that this transversion is likely not to be a common polymorphism.

We examined the X chromosome inactivation (XCI) status of five female carriers by using the androgen receptor locus and DNA isolated from peripheral blood. We found that XCI was notably skewed in all the informative carriers tested (fig 1D). In addition, only the wild-type allele was detected in leucocyte cDNA from II-1 carrier, further indicating that the mutant allele is indeed preferentially silenced (data not shown). Skewed XCI had also been noted in carriers of the original SRS family. ${ }^{6}$ These findings suggest that leucocytes expressing mutated SMS are negatively selected in vivo, which are in agreement with several other XLMR loci in which skewed XCI patterns has also been observed in healthy carriers. ${ }^{7}$
To investigate the effect of the p.G56S mutation on SMS protein function, we measured the SMS activity in immortalised lymphoblastoid cell lines (LCL) from three patients (III-2, III-11 and IV-3) and did not find any detectable enzyme activity (fig 2A). In addition, a reduction of spermine and a striking increase in the spermidine/spermine ratio (about sixfold that of the control) were observed in LCL from patient III-2 (fig 2B).

It is difficult to predict the residual activity of the mutated SMS in neuronal tissues and there is a possibility that the activity of the mutated enzyme varies according to tissue type. Cason et al ${ }^{3}$ observed similar reductions in enzyme activity and altered polyamine levels in both lymphoblastoid cells and fibroblasts from patients of the original SRS family. Therefore, it is possible that reduction in SMS activity and alterations in cellular polyamine content is a general phenomenon throughout the body of the affected individuals.

The glycine residue at position 56 in the $\mathrm{N}$-terminal region of SMS is highly conserved through evolution (fig 2C). Since SMS functions as a homodimer and its $\mathrm{N}$-terminal domain seems to be essential for SMS dimer formation, ${ }^{5}$ it is possible that the p.G56S substitution, which introduces a larger side chain, impairs SMS dimerisation and functioning. Since some spermine was present in the LCL of affected individual III-2, it is likely that some residual spermine synthase activity is present in vivo even though activity was below the limit of detection in the assays of cell extracts.

Mental retardation, speech and gait abnormalities, seizures, thickened lower lip, high arched palate, thin body build with muscle hypoplasia, kyphoscoliosis, osteosporosis, long 
hands/fingers, and hyperextensible fingers, were observed in affected males of both the original SRS family and our family, although with variable severity (table 1, fig 1B). Therefore, the data indicate these clinical findings are probably characteristic of SRS. Longer great toes and tall stature could not be evaluated adequately in the adult patient of the present family, but were not observed in the children, suggesting that these clinical presentations may be specific to the first reported family or, as commented previously, may become evident only after puberty. ${ }^{2} 3$ In addition, neither pectus excavatum nor facial asymmetry was observed in the patients of the family described here.

On the other hand, there are some clinical features that were observed mainly in patients with the p.G56S mutation including short philtrum, mandibular prognatism, ear abnormalities, high myopia and pectus carinatum. Furthermore, the psychomotor and cognitive development in these patients was more severely impaired as the two youngest boys were devoid of any social contact and were unable to talk, and the older male was able to follow only simple commands and spoke only few words. Additionally, control of seizures was difficult for all males despite treatment with high doses of different antiepileptic drugs. These findings point toward a greater pathogenicity of the p.G56S mutation compared to the splice site mutation found in the original SRS family, which seems to be associated with higher relative levels of enzyme activity compared to the present family.

Taken together, these results indicate that the p.G56S substitution leads to an even greater reduction in spermine levels and alteration of the relative levels of the polyamines, which would explain a more severe impairment of neuronal development and function. Additionally, the clinical discrepancies among the affected males from both families might also be attributed to differences in dietary habits, which may lead to different levels of dietary polyamines intake. ${ }^{8}$ This may also explain the fact that the phenotypes observed in male patients from both families are different from those described in the Sms knockout mouse model (the Gy mouse). ${ }^{9} 10$

In conclusion, this study describes the second mutation in the SMS gene to be associated with Snyder-Robinson syndrome, reports additional clinical features as part of the syndrome, supports a critical functional domain at the $\mathrm{N}$-terminal region of the SMS protein, and further indicates the critical role played by SMS in multiple systems, notably the central nervous system and skeleton.

Acknowledgements: We thank the members of the family for their cooperation and willingness to participate in this research. We also thank Constância G Urbani for secretarial assistance and Marta Canovas for technical contributions. Dedicated to the memory of Ethan Francis Schwartz 1996-1998.

Funding: This work was supported by grants from Fundação de Amparo à Pesquisa do Estado de São Paulo (FAPESP) and Conselho Nacional de Desenvolvimento Científico e Tecnológico (CNPq), NICHD grant (HD26202) to CES, NIH grant (GM26290) to AEP and, in part, by a grant from the South Carolina Department of Disabilities and Special Needs (SCDDSN).

Competing interests: None declared.

Patient consent: Obtained.

Ethics approval: The study was approved by the research ethics committee of the Institute of Biosciences, University of São Paulo, Brazil.

\section{REFERENCES}

1. Snyder RD, Robinson A. Recessive sex-linked mental retardation in the absence of other recognizable abnormalities. Report of a family. Clin Pediatr (Phila) 1969;8:669-74.

2. Arena JF, Schwartz C, Ouzts L, Stevenson R, Miller M, Garza J, Nance M, Lubs H. X-linked mental retardation with thin habitus, osteoporosis, and kyphoscoliosis: linkage to Xp21.3-p22.12. Am J Med Genet 1996;64:50-58.

3. Cason AL, Ikeguchi Y, Skinner C, Wood TC, Holden KR, Lubs HA, Martinez F, Simensen RJ, Stevenson RE, Pegg AE and Schwartz CE. X-linked spermine synthase gene (SMS) defect: the first polyamine deficiency syndrome. Eur J Hum Genet 2003;1:937-44

4. Ikeguchi Y, Bewley MC, Pegg AE. Aminopropyltransferases: function, structure and genetics. J Biochem (Tokyo) 2006;139:1-9.

5. Wu H, Min J, Zeng H, McCloskey DE, Ikeguchi Y, Loppnau P, Michael AJ, Pegg AE, Plotnikov AN. Crystal structure of human spermine synthase: implications of substratebinding and catalytic mechanism. J Biol Chem 2008 Mar 26 [Epub ahead of print].

6. Plenge RM, Hendrich BD, Schwartz C, Arena JF, Naumova A, Sapienza C, Winter RM, Willard HF. A promoter mutation in the XIST gene in two unrelated families with skewed X-chromosome inactivation. Nat Genet 1997;17:353-6.

7. Plenge RM, Stevenson RA, Lubs HA, Schwartz CE, Willard HF. Skewed Xchromosome inactivation is a common feature of $\mathrm{X}$-linked mental retardation disorders. Am J Hum Genet 2002;71:168-73.

8. Zoumas-Morse C, Rock CL, Quintana EL, Neuhouser ML, Gerner EW, Meyskens FL Jr. Development of a polyamine database for assessing dietary intake. J Am Diet Assoc 2007; 107:1024-7

9. Meyer RA Jr, Henley CM, Meyer MH, Morgan PL, McDonald AG, Mills C, Price DK. Partial deletion of both the spermine synthase gene and the Pex gene in the X-linked hypophosphatemic, gyro (Gy) mouse. Genomics 1998;1548:289-95.

10. Lorenz B, Francis F, Gempel K, Böddrich A, Josten M, Schmahl W, Schmidt J, Lehrach $H$, Meitinger T, Strom TM. Spermine deficiency in Gy mice caused by deletion of the spermine synthase gene. Hum Mol Genet 1998;7:541-7. 